\title{
30. THE LATE CENOZOIC DIATOMS OF SITES 183-193, LEG 19 DEEP SEA DRILLING PROJECT
}

\author{
Itaru Koizumi, Institute of Geological Sciences, College of General Education, Osaka University, Toyonaka, Osaka, Japan
}

\section{INTRODUCTION AND PREVIOUS WORK}

A large area of the sea floor of the North Pacific is occupied by siliceous sediments containing microfossils such as diatoms, silicoflagellata, and Radiolaria (Lisitsyn 1971). These siliceous sediments mainly consist of diatom valves, amorphous biogenous silica, except in the zone of radiolarian ooze north of the equator, around $10^{\circ} \mathrm{N}$ latitude (Riedel, 1959). The quantitative distribution of diatom valves in a unit weight of surface sediment layer of the Pacific Ocean was summarized by Jousé et al. $(1969,1971)$. The micropaleontological studies on the cores from the North Pacific, owing to the lack of good carbonate components have been carried out in the field of siliceous microfossils, especially of diatoms.

The first report on diatom stratigraphy in deep-sea cores from the North Pacific was done by Kolbe (1954). He showed that Tertiary species were restricted to the lower levels of core 76, taken by the Swedish Deep-Sea Expedition from the equatorial part of the Pacific, and that there is a distinct difference between the lower and upper parts of the core. Since Kolbe, a number of workers from the Soviet Union have been very active in the study of the diatoms in the deep-sea cores from the North Pacific and its neighboring seas; namely the Bering Sea, the Sea of Okhotsk, and the Sea of Japan. Through their systematic researches, the Russian workers have become convinced (e.g. Jousé, 1961d, 1962) that (a) the diatom thanatocoenoses in the uppermost layer of the bottom sediments depend to a large extent on the biocoenoses in the water masses above, (b) the species composition reflects the oceanographic conditions in the overlying water masses, (c) the geographical zonality of diatom assemblages in bottom sediments is well expressed in their present distribution in the Pacific Ocean, (d) climatic variations during the Quaternary caused the displacement of biogeographical zones in the ocean, synchronous with displacements of the upper water masses, and therefore (e) one may judge the thermal conditions at the time during the accumulation of sediments from the changes in the composition of diatom species (Jouse' 1961d). Reports on the diatom stratigraphy of deep-sea cores are as follows: Seczkina (1959), on the diatoms in a long core from the Sea of Japan; Jousé (1961a, b), on the correlation of horizons marked by diatoms in long cores from the northwestern part of the Pacific; Jouse' (1962), a thorough summary of diatom studies carried out by Russian workers in the Soviet Far East seas (Bering Sea, the Sea of Okhotsk, the Sea of Japan, and the northwestern part of the North Pacific); Jousé (1963), on the discussion of diatom stratigraphy of the deep-sea cores from the areas under different water masses in the northwestern Pacific; Jousé $(1969,1971 a)$, on the three types of diatom variation - quantitative, ecological, and phylogenetic - observed in some cores, including a long core, V20-119, from north of $40^{\circ} \mathrm{N}$ in the North Pacific; Muchina $(1969,1971)$, on the diatom stratigraphy in many deep-sea cores, including two cores from the equatorial parts of the Pacific which penetrated Pliocene sediments.

The geographical distribution of diatoms in modern deep-sea sediments of the North Pacific was also studied by Kanaya (1961) and Kanaya and Koizumi (1966). Kanaya and Koizumi (1966) defined a statistic, Td (diatom temperature) values, in the long core V20-130 from the North Pacific and discussed the fact that the structures of the diatom assemblages change from the upper part to the lowermost part in the core. Koizumi (1970a, b) reported the fluctuations of surface water temperatures during the late Quaternary in the Yamato Basin of the Sea of Japan and the Shikoku Basin of the Philippine Sea, as shown by diatoms in several deep-sea cores. Donahue (1970) defined diatom biostratigraphic zones in the late PliocenePleistocene by using paleomagnetic stratigraphy as a time scale and discussed climatic changes by the use of the $\mathrm{Td}$ values in deep-sea cores from the northern North Pacific. With reference to the diatom stratigraphy in the equatorial Pacific, Burckle (1972) compared the occurrence of selected Plio-Pleistocene diatoms with the paleomagnetic and other microfossil stratigraphy (Hays et al., 1969) and later defined a late Miocene to Recent diatom zonation for eastern equatorial Pacific sediments. Kanaya (1971) studied the diatom assemblages of the experimental Mohole sequence from the subtropical Pacific and correlated the sequence with the Swedish deep-sea core 76.

The Deep Sea Drilling Project has aided marine micropaleontology by collecting cores of continuous pelagic sediment dated back as far as the Mesozoic. Studies on these sediments by means of diatoms will shed light on many problems that have not been adequately studied to date, for example a clearer biostratigraphic correlation and age dating, the evolutionary developments of diatoms, and the preservational history of diatom remains in pelagic sediments.

All of the sites of Leg 19 of the Deep Sea Drilling Project yielded abundant diatoms. The Site localities are as follows (see Figure 1):

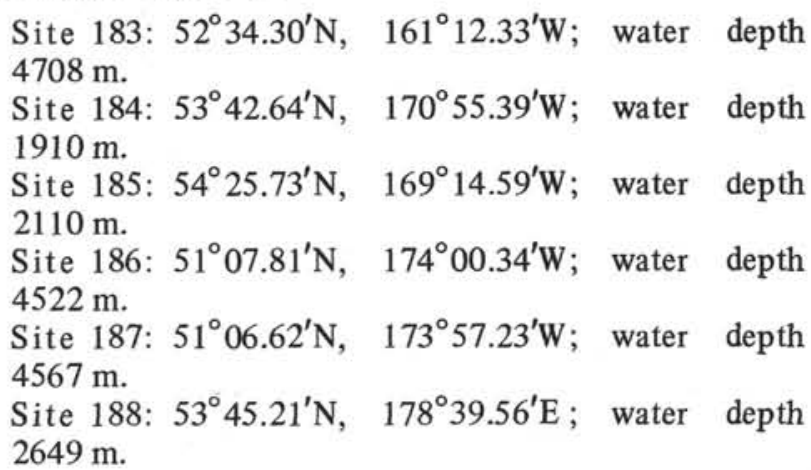




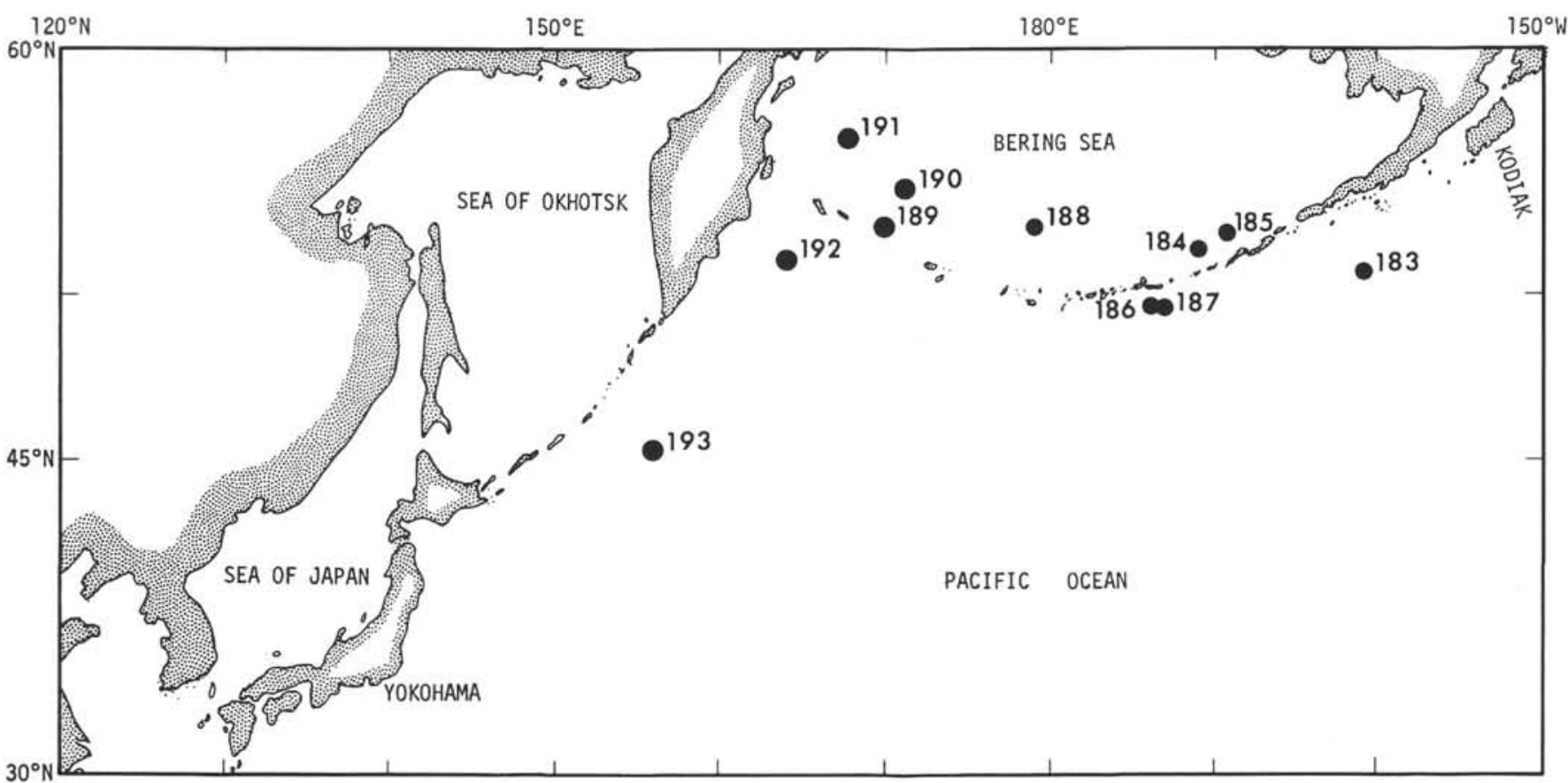

Figure 1. Location map of drilling sites in the Bering Sea and the Northern Pacific Ocean, Leg 19, Deep Sea Drilling Project.

Site 189: $54^{\circ} 02.14^{\prime} \mathrm{N}, \quad 170^{\circ} 13.38^{\prime} \mathrm{E}$; water depth $3437 \mathrm{~m}$.

Site 190: $55^{\circ} 33.55^{\prime} \mathrm{N}, \quad 171^{\circ} 38.42^{\prime} \mathrm{E}$; water depth $3875 \mathrm{~m}$.

Site 191: $56^{\circ} 56.70^{\prime} \mathrm{N}, \quad 168^{\circ} 10.72^{\prime} \mathrm{E}$; water depth $3014 \mathrm{~m}$.

Site 192: $53^{\circ} 00.57^{\prime} \mathrm{N}, \quad 164^{\circ} 42.81^{\prime} \mathrm{E}$; water depth $3014 \mathrm{~m}$.

Site 193: $45^{\circ} 48.20^{\prime} \mathrm{N}, \quad 155^{\circ} 52.27^{\prime} \mathrm{E}$; water depth $4811 \mathrm{~m}$.

Diatoms as old as middle Miocene were encountered at Sites 183 and 192. Upper Miocene diatoms were found at Sites $183,184,185,187,188,190$, and 192 ; Pliocene at all sites from 183 to 192; Quaternary at all sites. These sequences allowed a significant advance in the field of diatom biostratigraphy. The continuously cored sequences made possible a complete diatom biostratigraphy ranging from middle Miocene to Recent, the result of the combination of the diatom micropaleontology in the cores of the North Pacific and from land sections along its periphery, from Japan to California via Sakhalin, Kurile, and Kamchatka.

Paleoclimatic fluctuations for the Quaternary based on the percentage of cold-water diatoms, and paleosedimentogical changes, based on the occurrences of freshwater and benthonic diatoms, were studied.

Taxonomic references were made for all diatom taxa mentioned in the present paper. Most of the marine planktonic diatoms were illustrated.

\section{PREPARATION OF SAMPLES AND METHOD OF STUDY}

Samples for shore laboratory study of diatoms were taken aboard D/V Glomar Challenger from suitable levels in the core sections. The sample spacing in critical intervals was sufficiently close that bottoms and tops of selected species for the biostratigraphic zonation were determined with reasonable accuracy. During diatom studies on board the drilling vessel, it became apparent that most sediments, at all sites, contain abundant diatom valves and are almost entirely lacking in calcareous remains. Samples were treated in the following way:

Materials of about 1 gram were dropped into a $200 \mathrm{cc}$ beaker of boiling hydrogen peroxide solution $\left(\mathrm{H}_{2} \mathrm{O}_{2}, 15 \%\right)$. Upon cooling, the beaker was filled with distilled water. After about $10 \mathrm{sec}$, when clastic grains and volcanic glass sank to the lower part or bottom of the beaker, approximate quantities of the suspension containing diatom valves were taken by pipette from the middle part of the water column, then placed on a square cover glass, $18 \mathrm{~mm} \times 18$ $\mathrm{mm}$ in size. The glass was dried on a hot plate at moderate temperature and then mounted on a slide using Pleurax. Except for the case of a few limestone materials, preparations of hydrochloric acid $(\mathrm{HCl}, 25 \%)$ were not used.

By the use of a mechanical stage, the lines chosen in the center third of the cover glass were transversed using a lens combination of $\times 10$ widefield eyepieces and $\times 70$ oil immersion objective. All of the diatoms that appeared under the field while traversing the lines to count 200 specimens were identified except the genus Chaetoceros. Only specimens representing more than one-half of a diatom valve were counted, with the exception of genus Rhizosolenia. The frequencies of each taxon thus obtained by the single count of 200 specimens for each sample were not shown in the distribution charts (Tables 1-11).

\section{DIATOMS AT EACH SITE}

The occurrences of diatoms, zonal subdivision, and geological age are tabulated for each site. All of the tables 
contain the following information about each sample included in the present study: (1) Columns on the left indicate the depth below sea floor $(\mathrm{m})$, core recovery $(\mathrm{m})$, core number, section number, and the interval $(\mathrm{cm})$ of examined samples. Each core, which at full recovery comprises 9 meters of sediment, is divided into six sections of $150-\mathrm{cm}$ lengths. The sample numbers, which identify the relative position of samples in drilling holes, start with a series of numbered entries separated by hyphens, core number-section number. The series is followed by the interval below the top of each core section in centimeters. (2) The marine planktonic diatoms are classified into either the recurrent groups (Kanaya and Koizumi, 1966) or another that does not belong to the groups. The letters $C$ and $W$ indicate the cold- and warm-water diatoms. (3) Marine tychopelagic and benthonic diatoms are arranged alphabetically. Some fossil species, by analogies with the ecology of their living counterparts, and a few brackish-water diatoms, are listed within the same column. (4) Freshwater diatoms are plotted in alphabetical order in the tables of Sites 189, 190, and 191, where they were investigated in detail. (5) Six frequency grades for diatoms are distinguished. They are based on a random count of 200 specimens for each sample:
$\overline{\mathrm{A}}$ : very abundant, more than 100 .
A: abundant, 60 to 99 .
C: common, 40 to 59 .
F: few, 20 to 39 .
$\mathrm{R}$ : rare, 6 to 19 .
$\underline{\mathrm{R}}$ : very rare, 1 to 5 .

(6) Zone and geological age are found at the right of each table.

Each boundary of zonal subdivisions for each site is indicated in Table 12 with the number of the investigated samples. Some comments are added on the assemblages in the zone where necessary. The striped part in the column indicates that zonation was impossible through that part of the sequence.

After the preparation of this manuscript, Fragilariopsis cylindrus (Grun.) was transferred to Nitzschia cyclindrus (Grun.) as new combination by Hasle (1972).

\section{Site 183 (with Table 1)}

Site 183 is located near the northern edge of the Aleutian Abyssal Plain, western Gulf of Alaska. The upper 210 meters consists of diatom-rich silty clays and pure diatom ooze with frequently intercalated ash layers. Icerafted erratic pebbles occur above 127 meters.

Diatoms are abundant and well preserved in all cores from the surface to 201 meters below the sea floor, except four samples, at 52 meters $(7-3,32-34 \mathrm{~cm}), 100$ meters $(11-1,80-82 \mathrm{~cm})$, and about 120 meters $(12-1,90-92 \mathrm{~cm}$ and $12-3,80-82 \mathrm{~cm}$ ). These samples, taken from the neighborhood of ash layers and ice-rafted erratics, contain diatoms which are only moderate in abundance and preservation. All samples below 201 meters are barren of diatoms. The most continuously cored section from 0-201 meters below the sea floor (between $1-1,92-94 \mathrm{~cm}$ and 20 , CC) represents the diatom zones down to the Denticula lauta Zone, the upper part of the middle Miocene. The lower part of Core $18(18-4,80-82 \mathrm{~cm}$ and $18, \mathrm{CC})$ at about 178 meters below the sea floor appears to belong to the Denticula hustedtii Zone, judging from the change of species composition throughout this part, notwithstanding the absence of Denticula hustedtii.

Many marine benthonic species are restricted within the zones higher than the Actinocyclus oculatus Zone (lower Pleistocene). No freshwater diatoms were encountered through the section.

\section{Site 184 (with Table 2)}

Site 184 (Holes 184 and 184B) is located on the extremely southwestern corner of Umnak Plateau, southeastern Bering Sea. The sediments from the surface to 603 meters are olive gray clay-rich diatom ooze with mixtures of terrigenous sand and silt grains, and sporadic occurrences of light gray pumice ash, black volcanic sands and silts, and pumice erratics. Toward the base, clay increases slightly but gradually, while the pumice erratics decrease and induration increases.

Diatoms are abundant and well preserved in almost all cores from the surface to 599 meters below the sea floor (22, CC). Diatom valves abruptly disappear in Core 23, from 599 to 601 meters below the sea floor. The lithology of the core sediments is dominantly indurated black mudstone. Hole 184B is barren of diatoms. The Denticula seminae Zone in the samples of the surface Core 1 is followed by the Thalassiosira zabelinae Zone in the samples from 2-3 (130-132 cm) to 11 (CC) (between about 132 and 305 meters. The sediments which were washed out between the depth 4 and 128 meters below the sea floor presumably correspond to the missing two diatom zones, Rhizosolenia curvirostris and Actinocyclus oculatus zones.

Many marine neritic species occur through the all Pliocene part, especially in the upper part of the section: three Stephanopyxis species; $S$. horridus, $S$. inermis, and $S$. turris, and many Thalassiosira species; $T$. antiqua, $T$. gravida forma fossilis, T. nidulus, $T$. usatchevii, $T$. undulosa, and $T$. zabelinae. Marine tychopelagic and benthonic species were constantly observed through the section down to the upper Miocene.

\section{Site 185 (with Table 3)}

Site 185 is approximately $150 \mathrm{~km}$ northeast of Site 184 on the southern flank of the broad spur separating Bristol Canyon from Bering Canyon, southeastern Bering Sea. The sediments are hemipelagic clay-rich diatom ooze and diatomaceous silty clays to clayey silts without distinct lithologic changes. Thin, wholly terrigenous sand and silt layers, a few ash layers, and some limestone beds are locally present.

Diatoms are abundant to common. They are well preserved as far as $\mathbf{5 8 0}$ meters below the sea floor (down to 17, CC). About 600 meters below the sea floor (e.g., 18, $\mathrm{CC})$, the diatom content gradually decreases. From about 670 to 728 meters below the sea floor (between 21, CC and $27, \mathrm{CC})$ a few valves are observed to be in various stages of dissolution and alteration. The boundary of the Denticula seminae Zone and the Rhizosolenia curvirostris Zone still remains to be determined because of few occurrences of the 
TABLE 1

Diatoms at Site 183

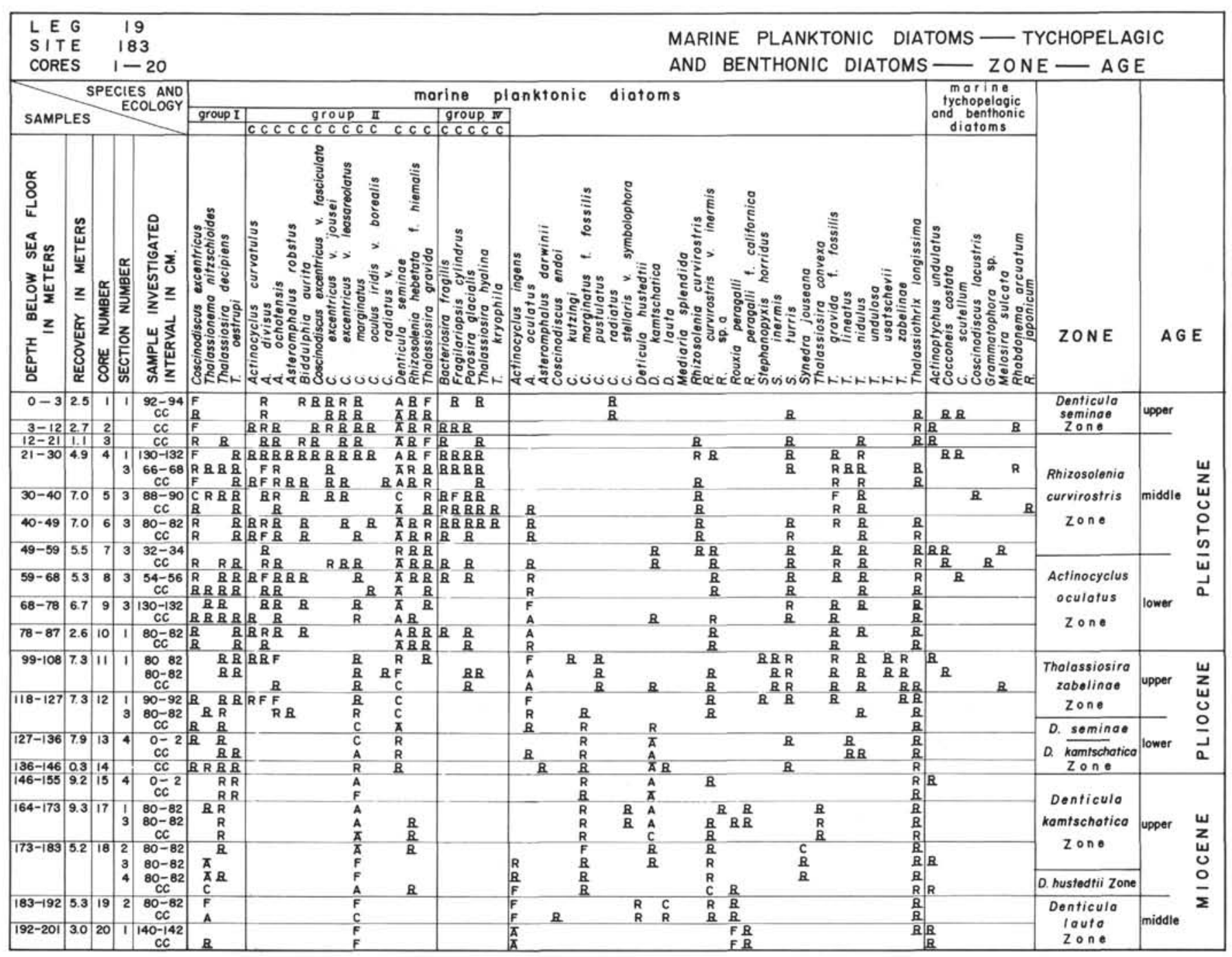

marker species. The Denticula seminae-Denticula kamtschatica Zone is recognized in only one sample $(8, \mathrm{CC})$. The Denticula kamtschatica Zone is more than 380 meters thick (between 9, CC and 17, CC, at 213 to $578 \mathrm{~m}$ below the sea floor). This appears to represent a high diatom productivity and increased influx of terrigenous materials in the upper Miocene.

In the Pliocene section at this site, marine neritic diatoms are not as abundant as at Site 184. Cyamatosira debyi, perhaps a benthonic form, judging from the ecology of the related living from Cyamatosira belgica, is frequently observed in the lower part of the Denticula kamtschatica Zone.

\section{Site 186 (with Table 4)}

At Site 186, located at the southern outer edge of the Atka Basin, Aleutian Ridge, a 926-meter sedimentary section of dominantly diatomaceous silty clay, with layers of ash, volcanic sands, and calcareous silt, was cored.
Diatoms are abundant and well preserved in the entire section, except in the lowermost part from 731 meters to 926 meters below the sea floor, where their occurrence is only common. Five diatom zones from Denticula seminae Zone to Denticula seminae-Denticula kamtschatica Zone were confirmed without breaks in the stratigraphic record.

There are occurrences of many middle Miocene index species (Sheshukova-Poretzkaya, 1967; Koizumi, in press)Eucampia balaustium, Goniothecium tenue, Kisseleviella carina, Raphidodiscus marylandicus, and Synedra jouseana, but only in sediments from the lower 1.5 meters of Core 23 (between 23-3, 50-52 $\mathrm{cm}$ and $23, \mathrm{CC}$, at $621.5 \mathrm{~m}$ to $627 \mathrm{~m}$ below the sea floor). The diatom assemblages in this section are different from the subarctic Pliocene assemblages. Therefore, the lower 1.5 meters of Core 23 is interpreted as a block of middle Miocene sediment which was physically emplaced within the lower Pliocene part. The fact that the lower 1.5 meters of Core 23 is an exotic block agrees with the different color of sediments and the different type of association of microfossils in this part. 
TABLE 2

Diatoms at Site 184

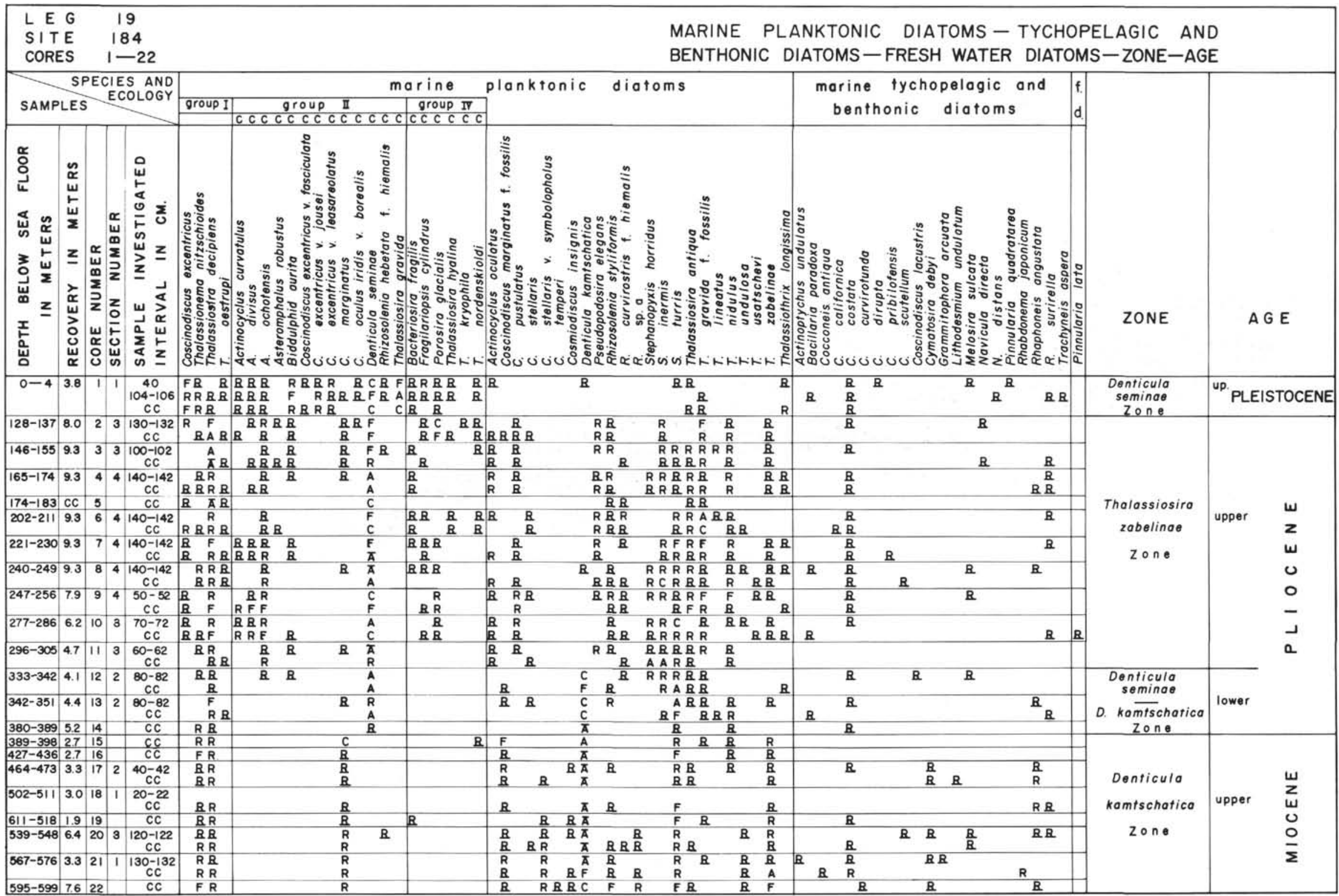


TABLE 3

Diatoms at Site 185

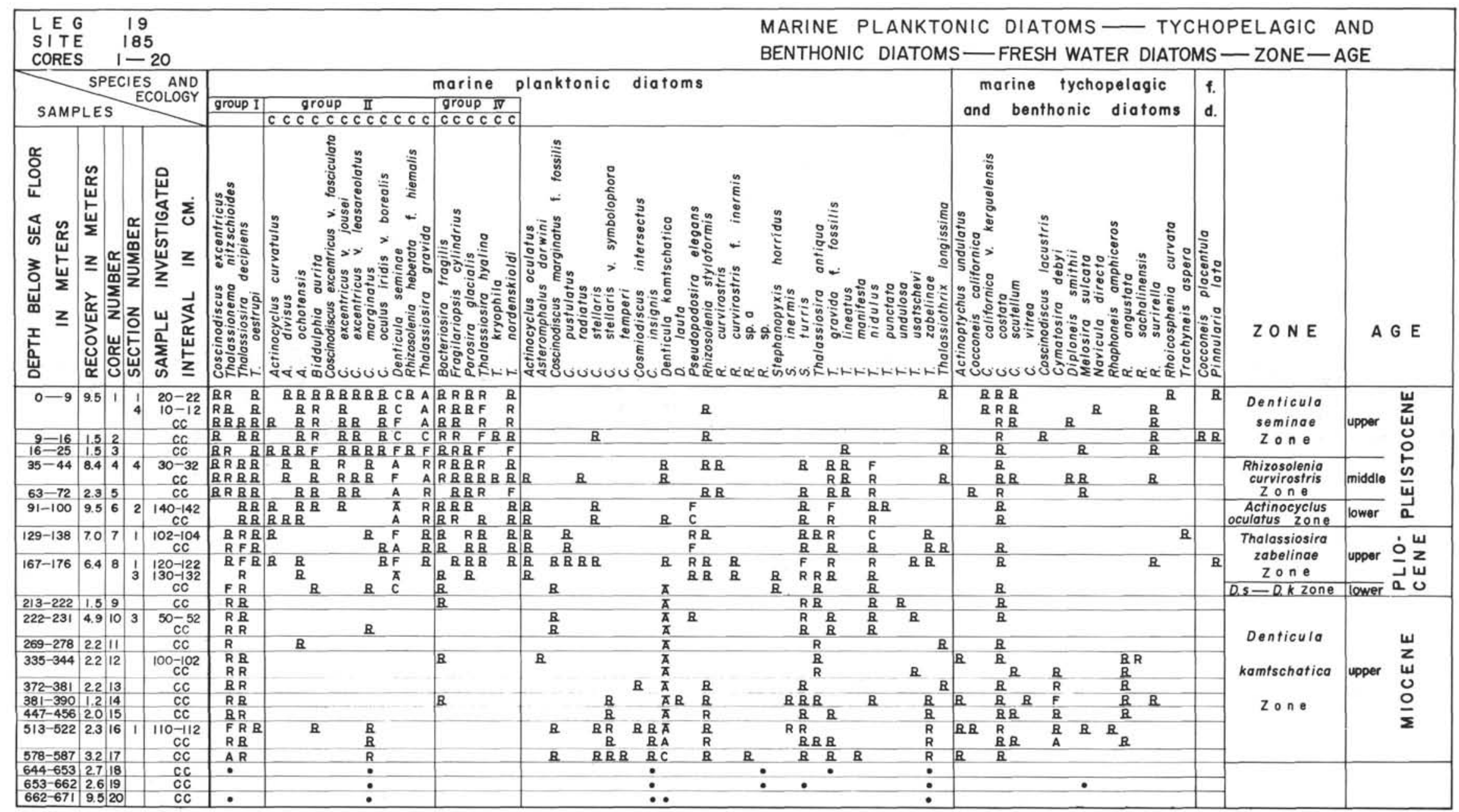


TABLE 4

Diatoms at Site 186

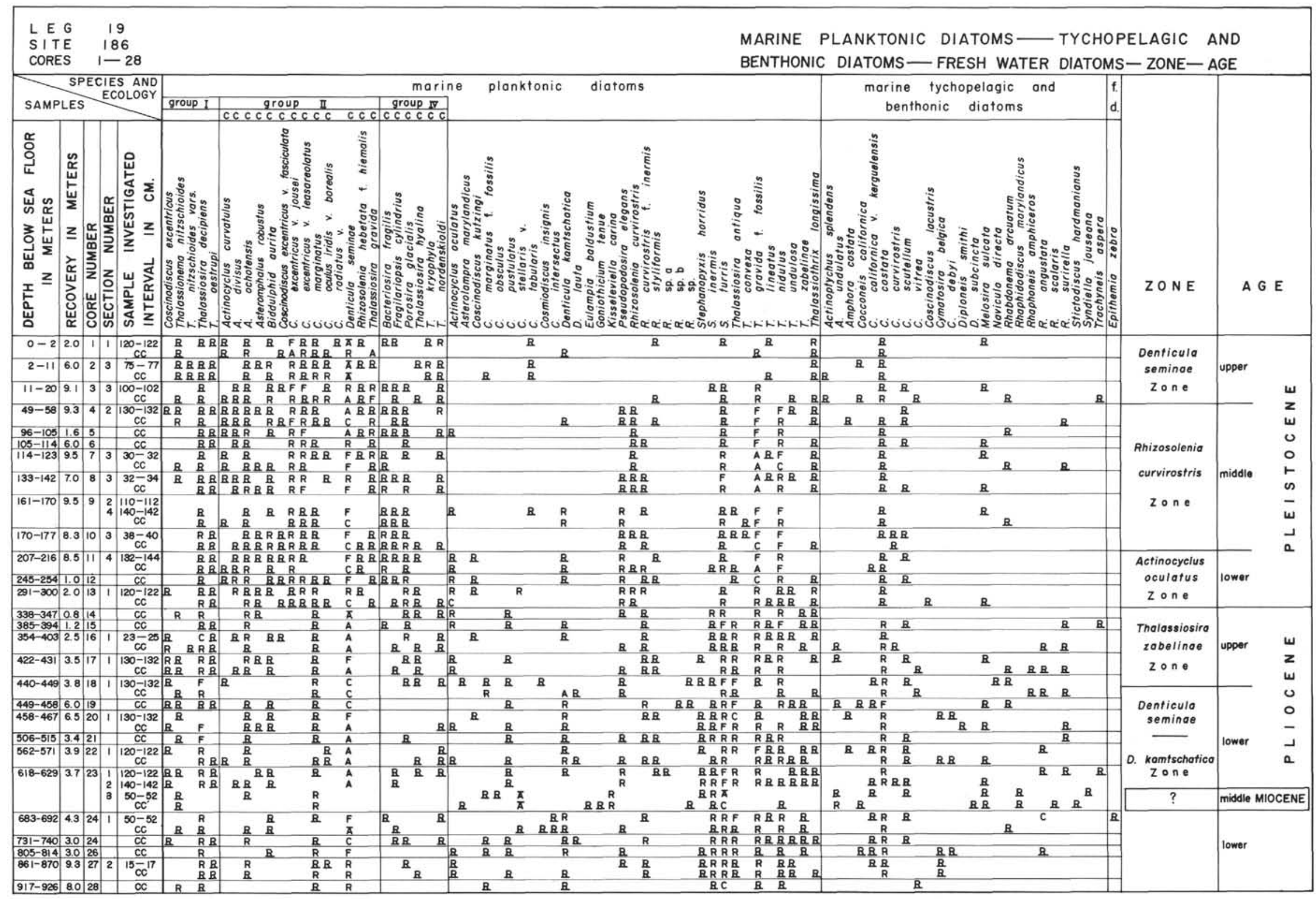


Many marine neritic diatoms and benthonic diatoms are found abundantly throughout the entire Pliocene section. A few reworked Miocene diatoms occur at various levels in the Plio-Pleistocene part.

\section{Site 187 (with Table 5)}

Site 187 is about $4 \mathrm{~km}$ southeast of Site 186 and is located on the inner part of the outer ridge of the Atka Basin, Aleutian Terrace. The four cores taken at the site consist of dark brownish gray and olive gray diatomaceous silty clays.

Diatoms are common, and sometimes poorly preserved, in the silty clay part of all four core catchers from 1 (CC) to 4 (CC). In the limestone fragments of core catchers 1 and 3 , they are abundant to common and well preserved.

The assemblage in the limestone fragments of Core 1 (1, CC, Lst) is Quaternary, but indigenous silty clays are in the Denticula seminae-Denticula kamtschatica Zone. Therefore, the limestone fragment probably represents caving from higher in the hole.

\section{Site 188 (with Table 6)}

Site 188 is located on the western flank of Bowers Ridge, Bering Sea. The sedimentary section at the site consists of 582 meters of diatom ooze, silt-rich diatom ooze, diatomaceous silt, and 56 meters of argillite.

Diatoms are abundant and well preserved within the upper unit of diatomaceous sediments. The argillite unit failed to yield any diatoms, except for valves of Coscinodiscus marginatus, which were altered and partly dissolved, in the uppermost sample $(16, \mathrm{CC}$, at 591 meters below the sea floor). Six continuous diatom zones, to the Denticula kamtschatica Zone, are recognized through the upper unit.

Marine tychopelagic and benthonic diatoms occur frequently in each zone. There are a few reworked Tertiary diatoms at some levels in the Quaternary.

\section{Site 189 (with Table 7)}

Site 189 is located at the base of the north flank of the Aleutian Ridge. Bering Sea. The sedimentary section consists of 370 meters of diatomaceous silty clay to clay-rich diatom ooze and 501 meters of silty claystone.

The abundance and preservation of diatoms in the samples from Site 189 are not as good as those from other Bering Sea sites (e.g., Sites 184, 185, and 188). The samples below Core 9 (at $426 \mathrm{~m}$ below the sea floor) contain few diatoms, and diatoms are very rare in Cores 11 and 12 (between 641 and $706 \mathrm{~m}$ below the sea floor). This is apparently due to the dominant influx of terrigenous materials. Deeper cores (between 13, CC and 20, CC, at 725 to $871 \mathrm{~m}$ below the sea floor) at this site have only highly altered and unidentifiable valves of diatoms. These valves are often pyritized or recrystallized to calcite. The sequences of four diatom zones were defined.

Many marine benthonic species are present in all zones. Several displaced freshwater species are found both above and below the Plio-Pleistocene boundary.

\section{Site 190 (with Table 8)}

Site 190 is located in the southwestern Aleutian Basin, just east of the southern terminus of the Shirshov Ridge,

TABLE 5

Diatoms at Site 187

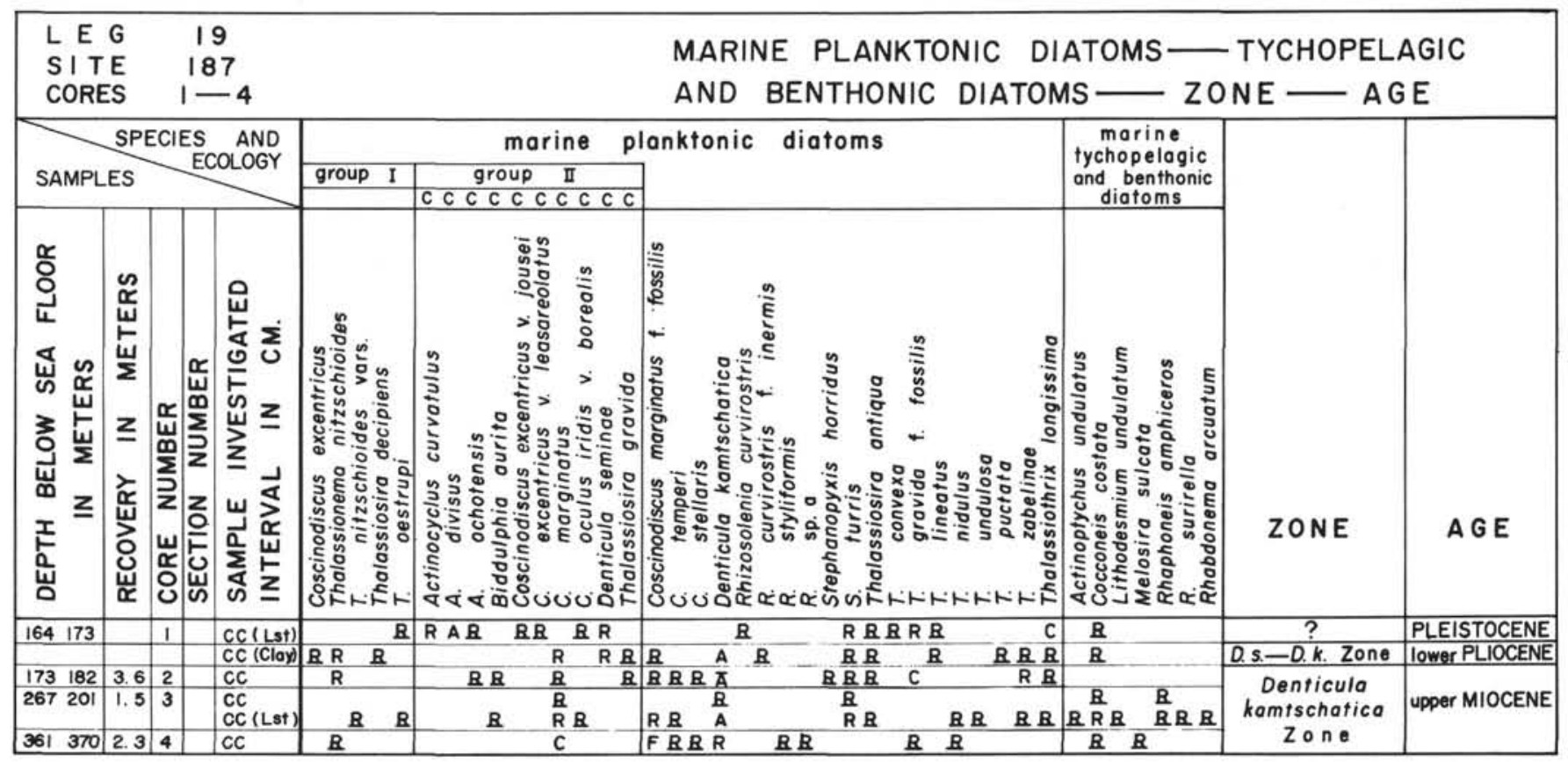


TABLE 6

Diatoms at Site 188

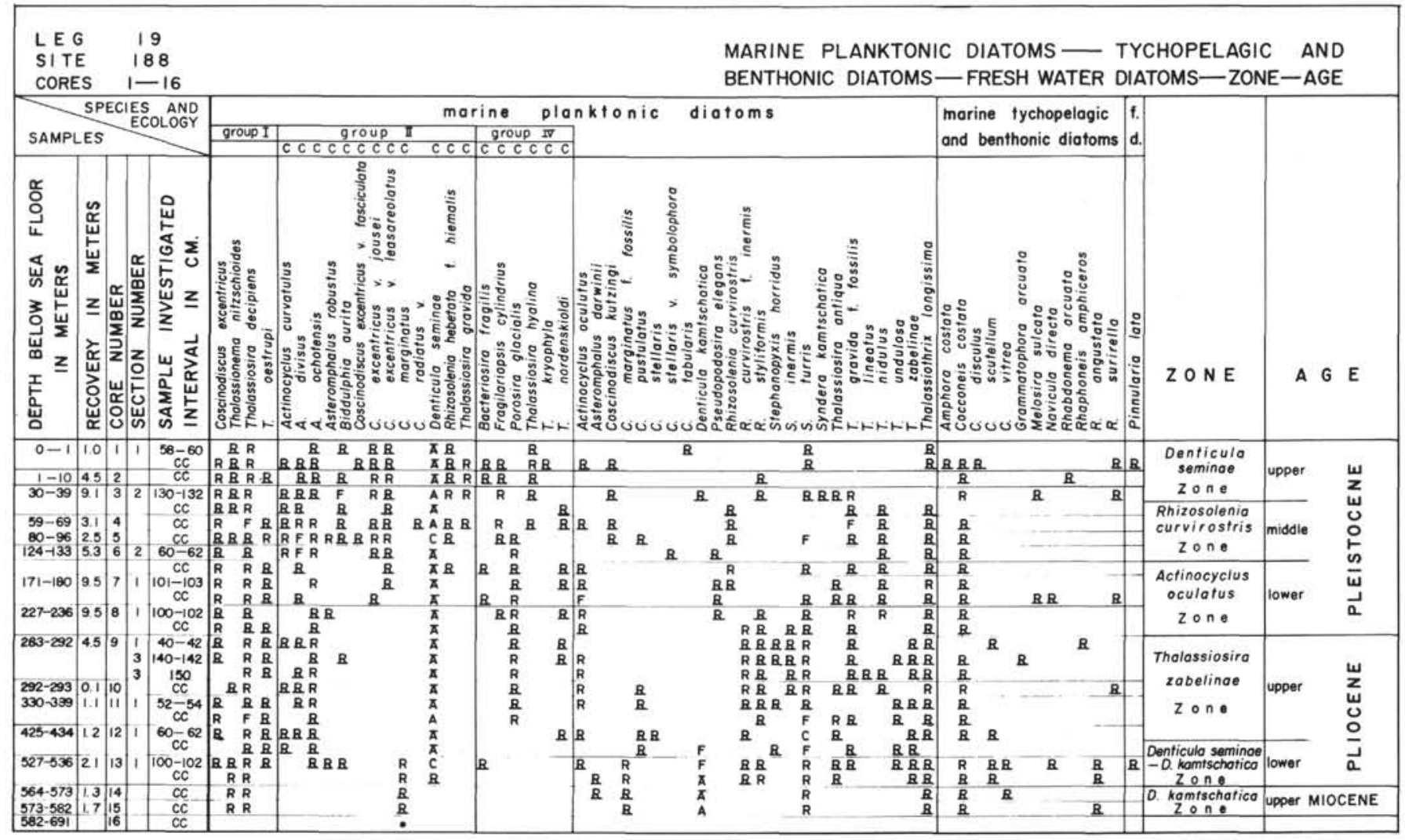

TABLE 7

Diatoms at Site 189

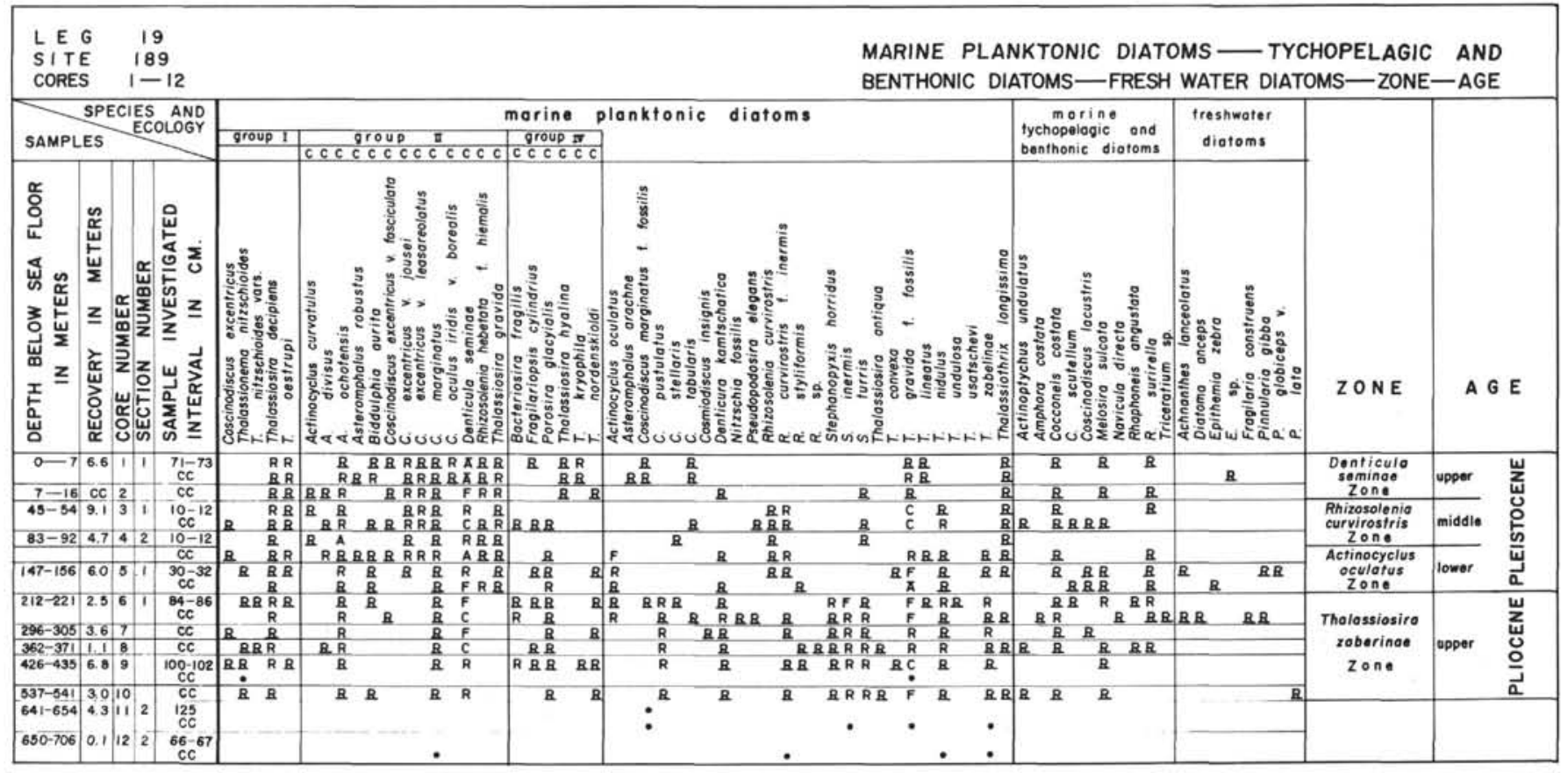


TABLE 8

Diatoms at Site 190

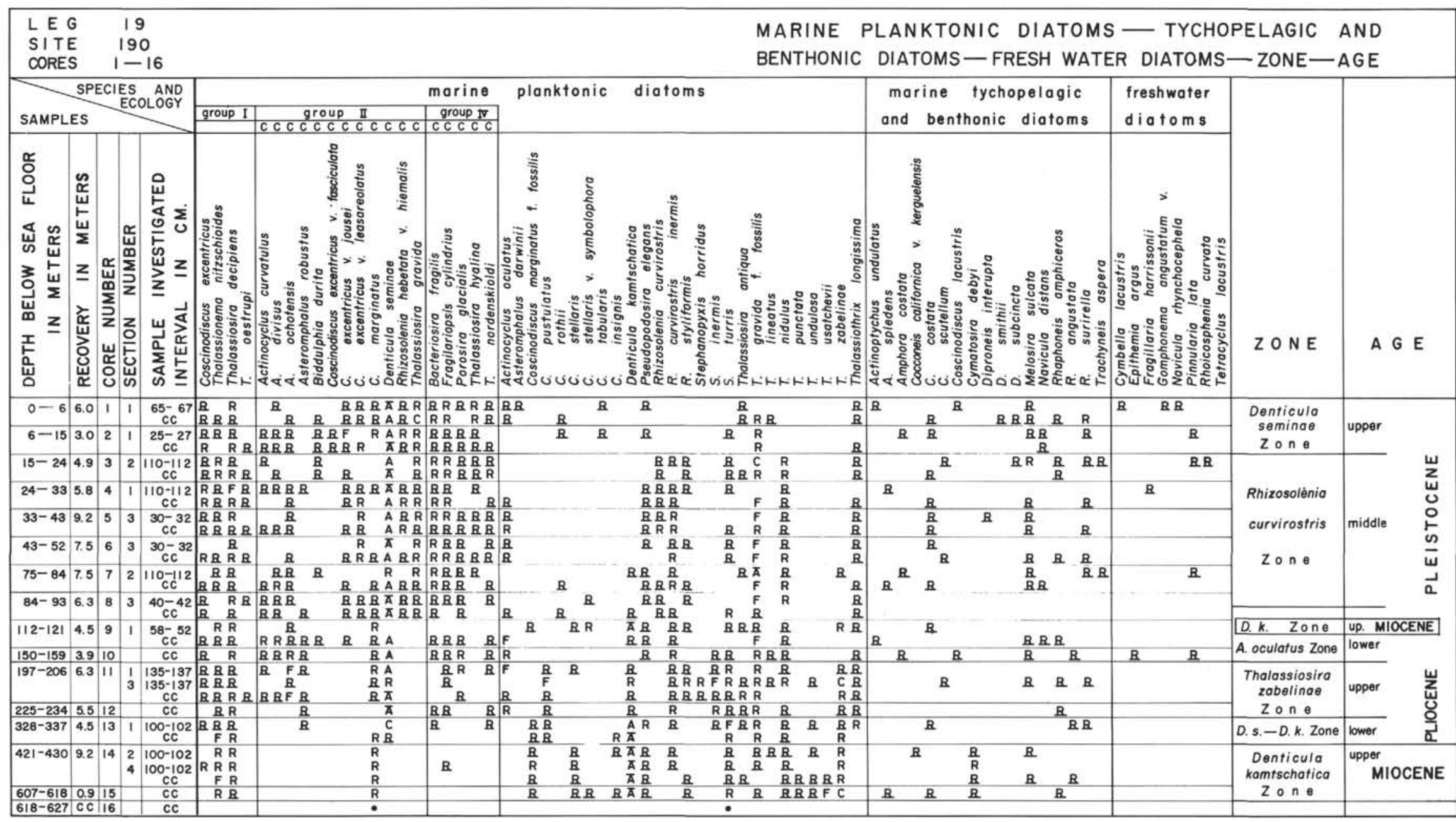


Bering Sea. The sedimentary section consists of 615 meters of diatomaceous silty clay and clay-to silt-rich diatom ooze, with layers of vitric volcanic ash and volcanic silt, and of 12 meters of mudstone, limestone, and clay.

Diatoms are abundant and well preserved throughout the entire section, except for the mudstone sediment. This contains only scattered valves which are corroded. By the tentative X-ray analyses, the presence of cristobalite in the mudstone of Core 16 (16, CC, $627 \mathrm{~m}$ below sea floor) indicates that the opal valves of diatoms presumably were transformed into cristobalite. Six diatom zones, to the Denticula kamtschatica Zone, are recognized without breaks. The assemblage in the sample at about 112 meters $(9-1,50-52 \mathrm{~cm})$ belongs to the Denticula kamtschatica Zone lying in Actinocyclus oculatus Zone, though other evidences (e.g., lithological and color changes) were not observed.

The limestone pebble caught in Core $16(16, \mathrm{CC})$ contains several middle Miocene diatoms besides other Miocene forms. They are Denticula lauta, Kisseleviella carina, and Synedra jouseana.

Marine tychopelagic and benthonic species are common through all sections. Cymatosira debyi is frequently found in the Denticula kamtschatica Zone. All freshwater diatoms and most sublittoral diatoms are present in the size-graded sands and silts of the upper 155 meters (between 1-1, 65-67 $\mathrm{cm}$ and $10, \mathrm{CC}$ ) of sediment. There are a few reworked Tertiary diatoms in the Quaternary part of the section.

\section{Site 191 (with Table 9)}

Site 191 is located on the east-central side of the Kamchatka Basin, just west of the Shirshov Ridge. The sedimentary section at this site consists of 520 meters of diatomaceous silty clay, diatom ooze, silty sand, and sandy silt, 380 meters of indurated silty clay and diatom-bearing silty clay, and 19 meters of basalt.

Diatoms are generally moderate, sometimes very rare in occurrence, and moderate to well preserved in the upper 520 meters of the section (down to $12-1,120-122 \mathrm{~cm}$ ). None are present in the deeper samples, except for altered and partly dissolved valves at the various levels. The X-ray analyses indicate the presence of quartz.

Marine tychopelagic and benthonic species continue to about 500 meters below the sea floor (down to 12-1, $120-122 \mathrm{~cm}$ ). Reworked extinct Tertiary and displaced freshwater species are found in the upper 300 meters of sandy and silty sediments (down to $8, \mathrm{CC}$ ).

\section{Site 192 (with Table 10)}

Site 192, a composite of Hole 192 and 192A, is located at the northwest end of the Emperor Seamount Chain. The sedimentary section consists of 140 meters of diatomaceous silty clay with volcanic ash beds, 565 meters of diatom ooze and diatom-rich clay, 235 meters of claystone, 104 meters of chalk and calcareous claystone with silts and sands, and 13 meters of basalt.

Diatoms are abundant and well preserved in all cores from the sea floor to a depth of about 500 meters (between $1-1,54-56 \mathrm{~cm}$ and $21, \mathrm{CC})$. From 500 to 730 meters (between 22-1, 100-102 $\mathrm{cm}$ and 26, CC) they are moderate in abundance and preservation. In this part of the section induration of the sediments gradually increases downward to semi-lithified diatom ooze and diatom-rich clay. Below 718 meters $(26, \mathrm{CC})$ diatoms are scattered and they are too

TABLE 9

Diatoms at Site 191

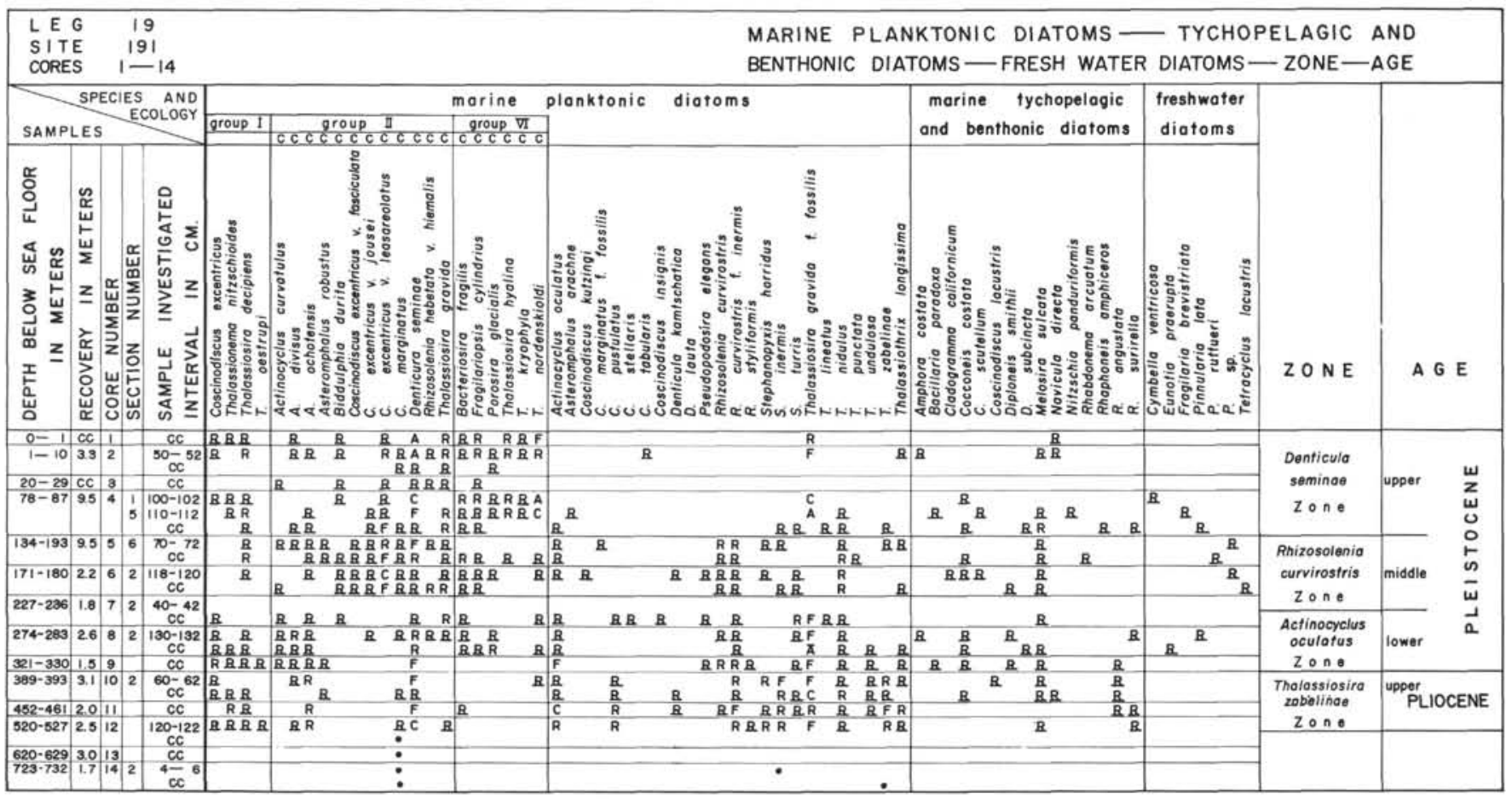




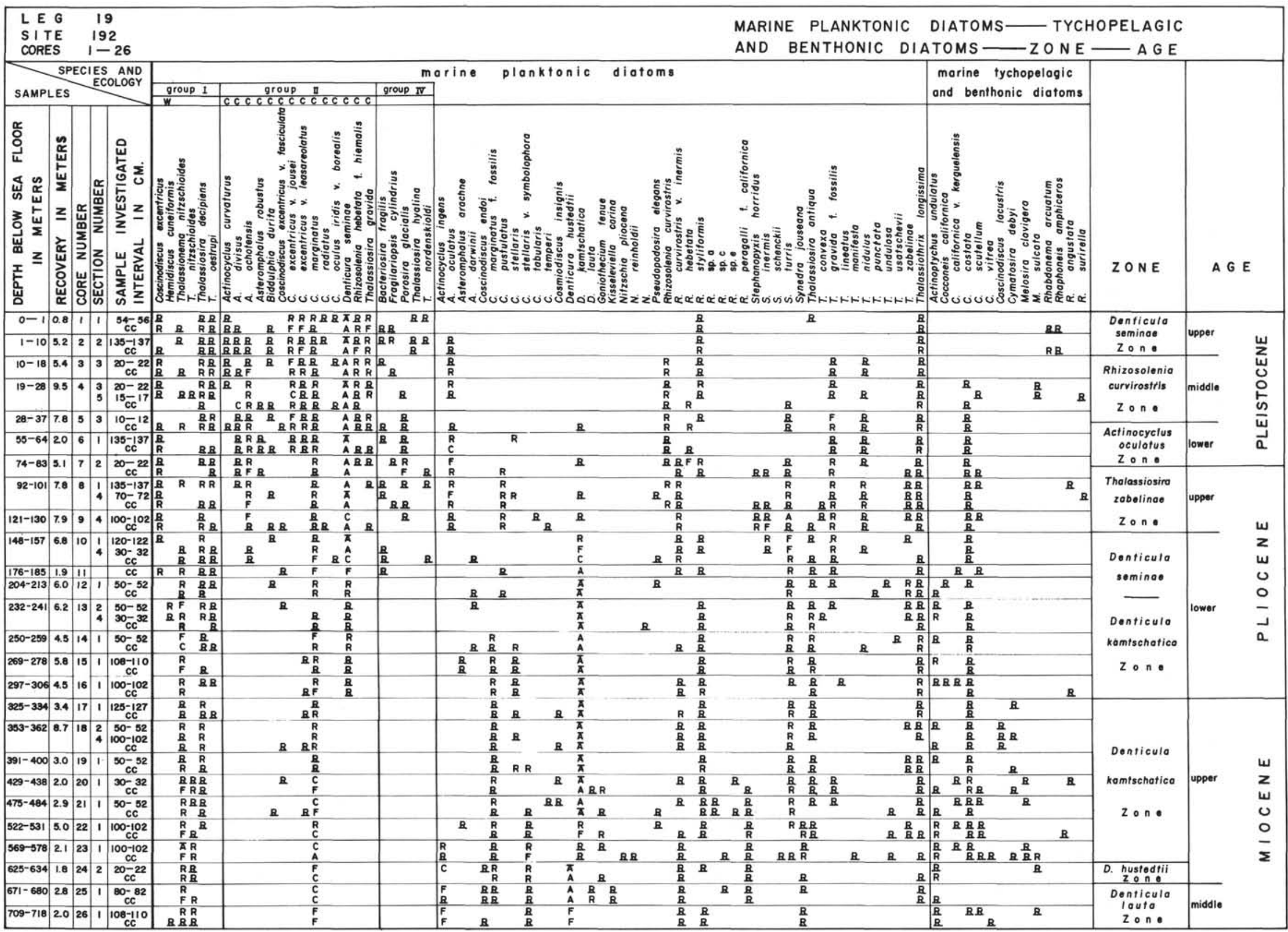


poor in preservation to identify the taxon. The X-ray data on sediments of Cores 27 and 31 (27, CC and 31, CC, at 755 and $995 \mathrm{~m}$ below the sea floor) indicate the dominance of clay minerals and a negligible amount of quartz and cristobalite. It may be due to primary lack of diatom valves in these samples. The eight diatom zones are recognized and are continuous throughout the entire diatomaceous section.

A few reworked Tertiary diatoms are found in the Quaternary part of the section. No freshwater forms are encountered in the section.

\section{Site 193 (with Table 11)}

At Site 193, located just west of the Hokkaido Rise, 71 meters of ash-bearing diatomaceous silty clay to clayey diatom ooze were cored.

Diatoms are more abundant in Cores 1 and 2 (between the surface and $11 \mathrm{~m}$ below the sea floor) than in the samples of Cores 3 and 4 (between 25 and $71 \mathrm{~m}$ below the sea floor). The preservation of valves is not always good, because of high percentage of volcanic glass and terrigenous silt content. Only the Quaternary diatom zones were defined.

There are some marine benthonic species through the section. No freshwater species are found.

\section{TIME RANGES OF SELECTED TAXA AND BIOSTRATIGRAPHIC ZONATION}

In order to correlate the sequences cored at the various sites and to determine a diatom zonation for the northern circum-Pacific region, it was attempted to subdivide the diatomaceous sequences into zones on the basis of marine planktonic diatoms. Not all species listed as marine planktonic diatoms in Tables 1-11 have the same biostratigraphic importance. The species were screened by their relative frequencies. Eliminated were those species which show either uniform or too sporadic occurrence, and those which, in previous records of occurrence, appear not to be time-stratigraphically important. For this purpose, the records of previous works were used as guides. These are Burckle (1972), Donahue (1970), Hanna (1932, 1970), Hays et al. (1969), Jousé (1962, 1969, 1971a), Kanaya (1959, 1971), Kanaya and Koizumi (1966, 1970), Koizumi (1968, 1972, in press), Lohman (1948), Mertz (1966), Muchina (1965), Nakaseko et al. (1972a, b), Sawamura (1963a, 1963b), Sawamura and Yamaguichi (1961, 1963), Sheshukova-Poretzkaya (1967), Simonsen and Kanaya (1969), and Wornadt (1967). Finally, thirtythree species were selected as criteria on which the zonal subdivisions of the sequences of all sites could be made. Their vertical distribution was examined separately for the section from each site.

As a typical example of subdivision of a sequence into diatom zones, Figures 2 and 3 present the ranges of taxa and the boundaries between diatom zones, corresponding to depth below the sediment surface against a vertical scale at Sites 183 and 192. Figure 4 shows the compiled range of taxa and the boundaries between diatom zones which were determined by means of the range chart for each site. This subdivision was under the following principles, according to Riedel and Sanfilippo (1970): (a) the base of each zone is defined by the first occurrence of a taxon that is easily recognizable, of known ancestry, of wide geographic distribution, and represented by numerous specimens in the

TABLE 11

Diatoms at Site 193

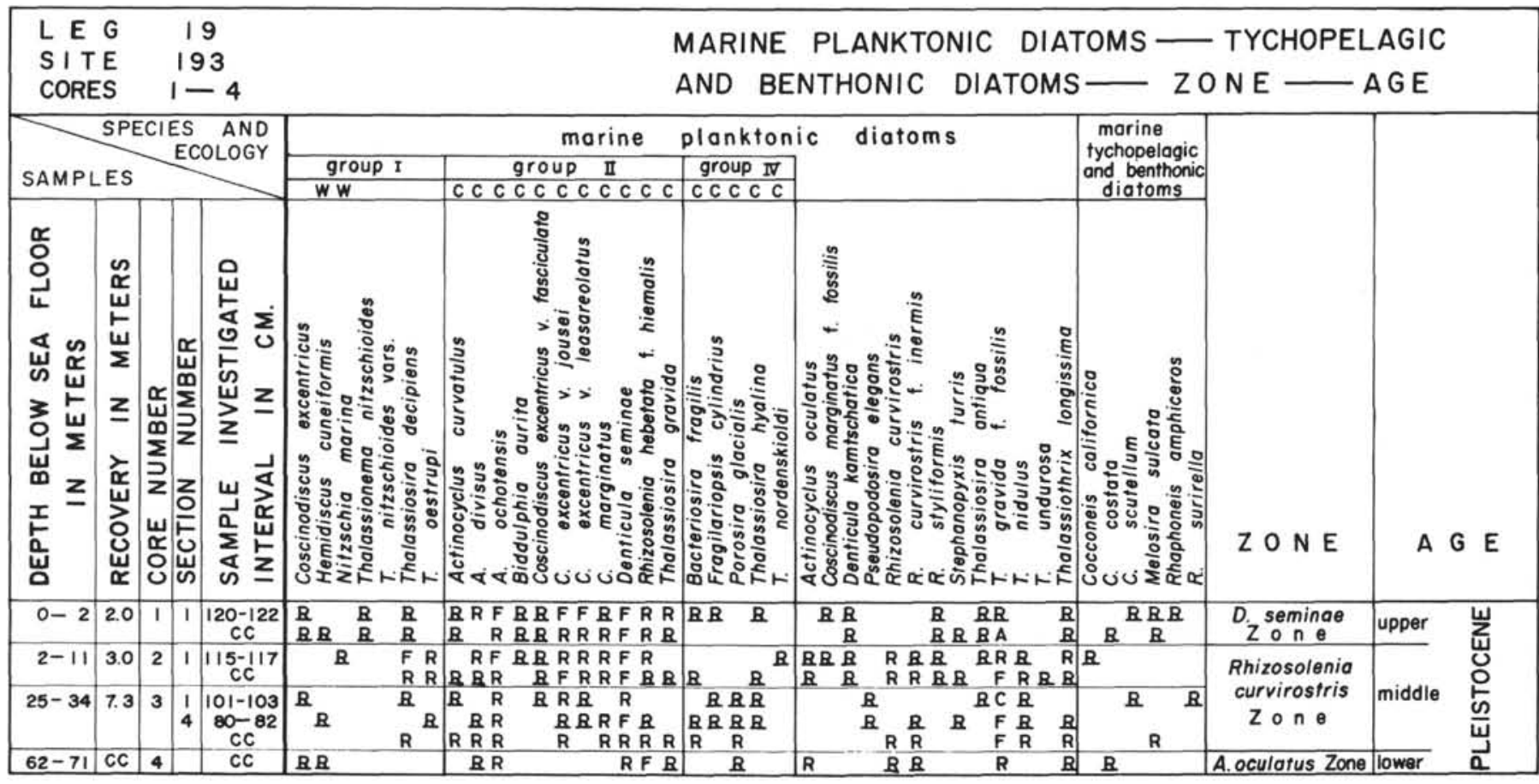




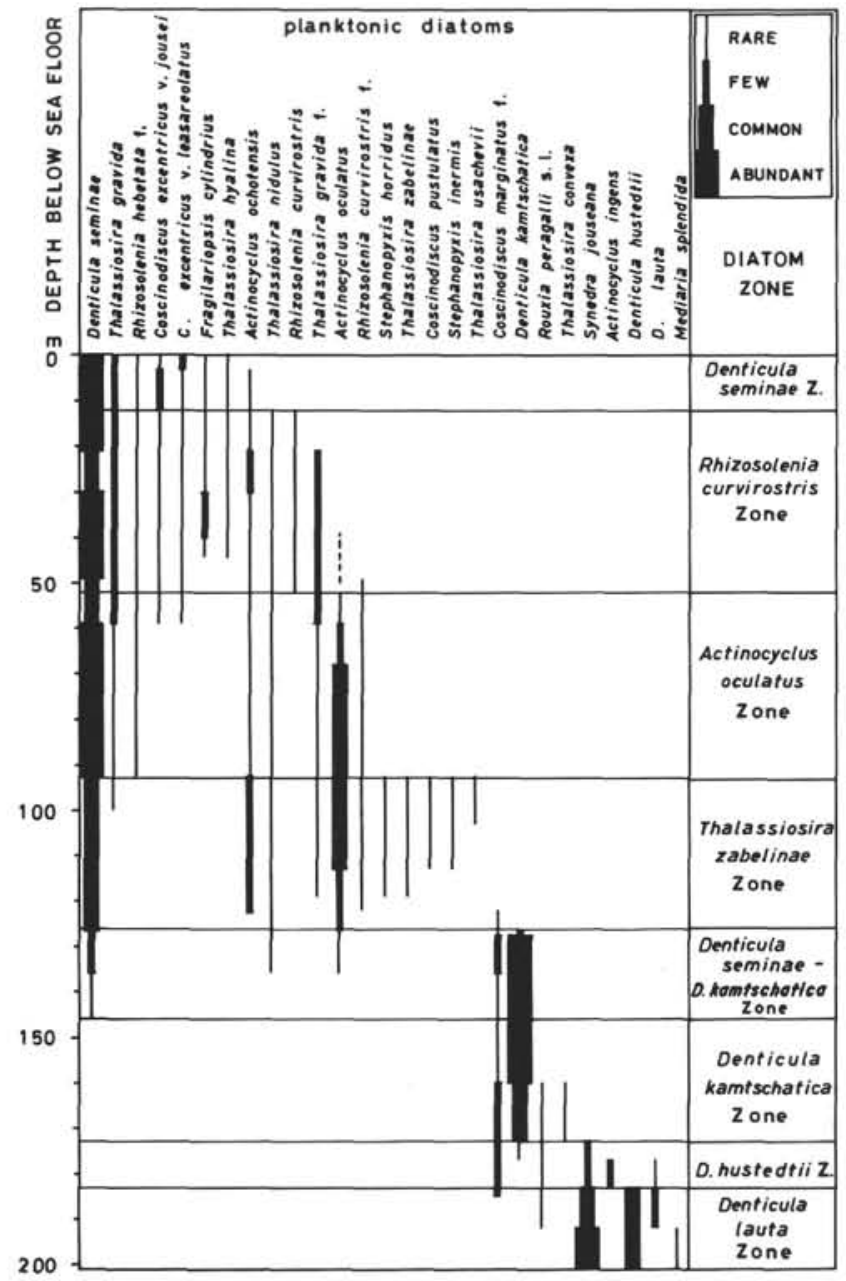

Figure 2. Stratigraphic ranges of selected marine planktonic diatoms and zonal subdivisions at Site 183, northeastern Pacific Ocean.

assemblages in which it occurs. (b) Each zone should include the first or last occurrences of several taxa-i.e., should be a concurrent range zone. Because of this, and since some taxa undergo considerable morphologic evolution within zones, it may be possible in some cases to correlate remote samples with the upper, middle, or lower part of some of the zones defined here.

The diatom zonation, therefore, applicable to the Leg 19 sequences is identical with the zonal schemes of Donahue (1970) in which the early Pleistocene to Pliocene parts in several core samples were checked by Koizumi for this study, and by Koizumi (in press). The scheme was applied successfully wherever selected taxa are present. The zones are listed from older to younger.

\section{Denticula lauta Partial-range-zone}

Definition: The base of this zone is not defined. The top is defined by the latest occurrences of Denticula lauta, and also of Kisseleviella carina at several sites.

Remarks: The zone includes the latest occurrence of Mediaria splendida.

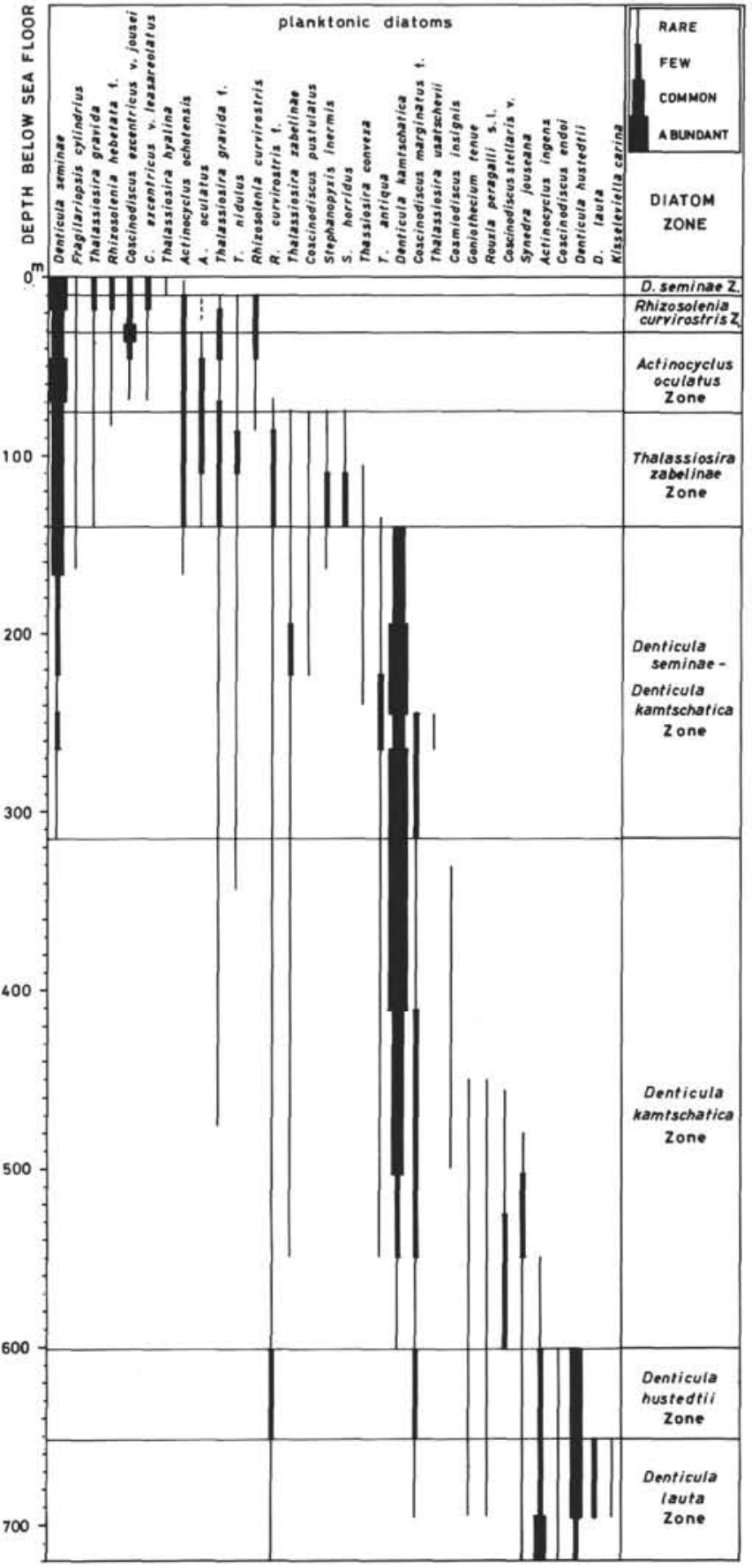

Figure 3. Stratigraphic ranges of selected marine planktonic diatoms and zonal subdivisions Site 192, northwestern Pacific Ocean.

\section{Denticula hustedtii Partial-range-zone}

Definition: The base of the zone follows immediately the top of the Denticula lauta Zone. The top is defined by the latest occurrences of Denticula hustedtii and Coscinodiscus endoi.

Remarks: The occurrence of Actinocyclus ingens s.l. remarkably decreases at the top of this zone. 


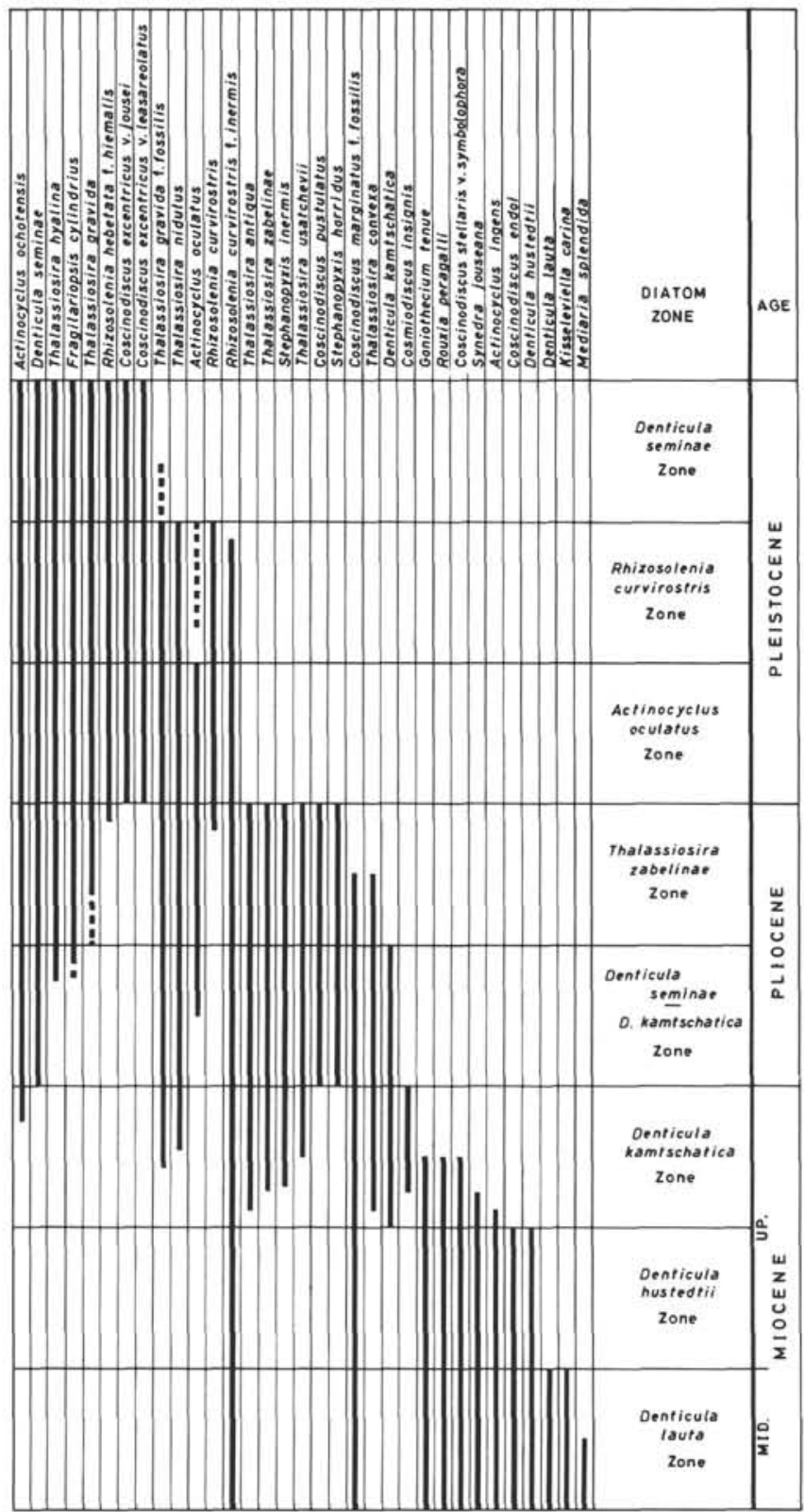

Figure 4. Compiled stratigraphic ranges of selected marine planktonic diatoms and zonal subdivisions, Sites 183 to 193, Leg 19, Deep Sea Drilling Project.

\section{Denticula kamtschatica Partial-range-zone}

Definition: The base of this zone is defined by the earliest appearances of Denticula kamtschtica, and of Coscinodiscus stellaris var. symbolophorus. The top borders the base of the following Denticula seminae-Denticula kamtschatica Zone, which is approximately synchronous with the latest occurrence of Cosmiodiscus insignis at several sites.

Remarks: The range of Coscinodiscus stellaris var. symbolophorus is only the lower part of this zone and that of Cosmiodiscus insignis is included only in the upper part. Therefore, this zone may be subdivided into subzones at a few sites. Within this zone many other events are included: The earliest appearance of Thalassiosira antiqua, Thalassiosira zabelinae, Stephanopyxis inermis, and Thalassiosira gravida forma fossilis in the lower part; the latest occurrences of Synedra jouseana, Actinocyclus ingens s.l., Goniothecium tenue, and Rouxia peragalli in the middle part; and the first appearances of Thalassiosira nidulus, Thalassiosira usatschevii, and Actinocyclus ochotensis in the upper part.

\section{Denticula seminae-Denticula kamtschatica Concurrent- range-zone}

Definition: This zone is defined by the first appearance of Denticula seminae at its base and the extinction of Denticula kamtschatica at its top.

Remarks: The earliest occurrences of Coscinodiscus pustulatus and Stephanopyxis horridus are recognized at the base of this zone. The zone includes the earliest occurrence of Actinocyclus oculatus and Thalassiosira hyalina.

\section{Thalassiosira zabelinae Partial-range-zone}

Definition: The base is just after the top of Denticula seminae-Denticula kamtschatica Zone, which is approximately synchronous with the earliest appearance of Thalassiosira gravida. The top of this zone is defined by the latest occurrences of the following species; namely, Coscinodiscus pustulatus, Stephanopyxis horridus, Stephanopyxis inermis, Thalassiosira antiqua, Thalassiosira usachevii, and Thalassiosira zabelinae.

Remarks: Events within this zone are the latest occurrences of Coscinodiscus marginatus forma fossilis and Thalassiosira convexa, and the earliest appearances of Rhizosolenia curvirostris and Rhizosolena hebetata forma hiemalis.

Actinocyclus oculatus Partial-range-zone (Donahue, 1970; except for the definition of the base of the zone)

Definition: The base of this zone is just after the top of the Thalassiosira zabelinae Zone, which is approximately synchronous with the earliest appearances of Coscinodiscus excentricus var. jousei and var. leasareolatus. The top is defined by the latest occurrence of Actinocyclus oculatus.

Remarks: A few speciments of Actinocyclus oculatus are usually observed in the upper zone with a break after the continuous occurrences in this zone.

Rhizosolenia curvirostris Partial-range-zone (Donahue, 1970.)

Definition: The base of this zone is just after the top of the Actinocyclus oculatus Zone. The top is defined by the latest occurrences of Rhizosolenia curvirostris and Thalassiosira nidulus.

Remarks: This zone includes the accessory occurrence of Actinocyclus oculatus. 
TABLE 12

Diatom Zonation and Rock Intervals of Samples Studied at Each Site, Leg 19, Deep Sea Drilling Project

\begin{tabular}{|c|c|c|c|c|c|c|c|c|c|c|c|}
\hline ZONE SITE & 183 & 184 & 185 & 186 & 187 & 188 & 189 & 190 & 191 & 192 & 193 \\
\hline $\begin{array}{l}\text { Denticula } \\
\text { seminae } \\
\text { Zone }\end{array}$ & 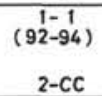 & $\begin{array}{l}1-1 \\
\left(40^{1}\right) \\
1-c C\end{array}$ & 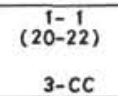 & 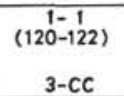 & & $\begin{array}{c}1-1 \\
(58-60) \\
3-2 \\
(130-132)\end{array}$ & $\begin{array}{r}\begin{array}{r}1-1 \\
(71-73) \\
2-C C\end{array} \\
\text { - }\end{array}$ & 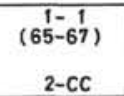 & $\begin{array}{l}1-C C \\
4-C C\end{array}$ & $\begin{array}{c}1-1 \\
(54-56) \\
2-C C\end{array}$ & $\begin{array}{c}1-1 \\
(120-122) \\
1-C C\end{array}$ \\
\hline $\begin{array}{c}\text { Rhizosolenia } \\
\text { curvirostris } \\
\text { Zone }\end{array}$ & $\begin{array}{c}3-C C \\
7-3 \\
(32-34)\end{array}$ & & $\begin{array}{c}\left(\begin{array}{c}4-4 \\
(30-32) \\
5-c C\end{array}\right. \\
\text { s }\end{array}$ & $\begin{array}{c}4-2 \\
(130-132) \\
10-C C\end{array}$ & $\begin{array}{c}1-c c \\
\text { (Lst.) }\end{array}$ & $\begin{array}{c}3-C C \\
6-2 \\
(60-62)\end{array}$ & $\begin{array}{c}3-1 \\
(110-112) \\
4-2 \\
(10-12)\end{array}$ & $\begin{array}{c}33-2 \\
(110-112) \\
8-3 \\
(40-42)\end{array}$ & $\begin{array}{c}5-6 \\
(70-72) \\
6-\mathrm{Cc}\end{array}$ & $\begin{array}{c}3-3 \\
(20-22) \\
5-3 \\
(10-12)\end{array}$ & $\begin{array}{c}2-1 \\
(115-117) \\
3-C C\end{array}$ \\
\hline $\begin{array}{c}\text { Actinocyclus } \\
\text { oculatus } \\
\text { Zone }\end{array}$ & $\begin{array}{l}7-C C \\
10-c C\end{array}$ & & $\begin{array}{c}6-2 \\
(140-142) \\
6-C C\end{array}$ & $\begin{array}{c}11-4 \\
(132-134) \\
13-\mathrm{CC}\end{array}$ & & $\begin{array}{l}6-C C \\
8-C C\end{array}$ & $\begin{array}{l}4-C C \\
5-C C\end{array}$ & $\begin{array}{l}8-C C \\
10-c c\end{array}$ & $\begin{array}{l}7-C C \\
9-C C\end{array}$ & $\begin{array}{c}5-C C \\
7-2 \\
(20-22)\end{array}$ & $4-C C$ \\
\hline $\begin{array}{c}\text { Thalassiosira } \\
\text { zabelinae } \\
\text { Zone }\end{array}$ & $\begin{array}{c}11-1 \\
(80-82) \\
12-3 \\
(80-82)\end{array}$ & $\begin{array}{c}22-3 \\
(130-132) \\
11-c C\end{array}$ & $\begin{array}{c}7-1 \\
(102-104) \\
8-3 \\
(130-132)\end{array}$ & $\begin{array}{c}14-C C \\
18-1 \\
(130-132)\end{array}$ & & $\begin{array}{c}9-1 \\
(40-42) \\
12-1 \\
(60-62)\end{array}$ & $\begin{array}{c}\begin{array}{c}6-1 \\
(84-86) \\
10-c C\end{array} \\
10\end{array}$ & $\begin{array}{c}\begin{array}{c}11-1 \\
(135-137) \\
12-C C\end{array} \\
\end{array}$ & $\begin{array}{c}10-2 \\
(60-62) \\
12-1 \\
(120-122)\end{array}$ & $\begin{array}{l}7-c c \\
9-c c\end{array}$ & \\
\hline $\begin{array}{c}\text { Denticula_seminae } \\
\text { O. kamtschatica } \\
\text { Zone }\end{array}$ & $12-C C$ & $\begin{array}{l}12-2 \\
(80-82)\end{array}$ & B-CC & 18-CC & $1-c c$ & $12-\mathrm{CC}$ & & $\begin{array}{c}13-1 \\
(100-102)\end{array}$ & & $\begin{array}{c}10-1 \\
(120-122)\end{array}$ & \\
\hline $\begin{array}{c}\text { Zone } \\
\text { Denticula } \\
\text { kamtschatica } \\
\text { Zone }\end{array}$ & $\begin{array}{l}14-C C \\
15-4 \\
(0-2) \\
18-3 \\
(80-82)\end{array}$ & $\begin{array}{l}14-C C \\
15-C C \\
22-C C\end{array}$ & $\begin{array}{l}9-\mathrm{CC} \\
17-\mathrm{CC}\end{array}$ & $28-c c$ & $\begin{array}{l}2-C C \\
4-C C\end{array}$ & $\begin{array}{l}\frac{13-C C}{14-C C} \\
15-C C\end{array}$ & & $\begin{array}{c}13-\mathrm{CC} \\
\frac{14-2}{(100-102)} \\
15-\mathrm{CC}\end{array}$ & & $\begin{array}{c}16-\mathrm{CC} \\
\begin{array}{c}17-1 \\
(125-127) \\
23-\mathrm{CC}\end{array}\end{array}$ & \\
\hline $\begin{array}{c}\begin{array}{c}\text { Denticula } \\
\text { hustedtii } \\
\text { Zone }\end{array} \\
\text { Denticula } \\
\text { lauta } \\
\text { Zone }\end{array}$ & $\begin{array}{c}18-4 \\
(80-82) \\
18-C C \\
19-2 \\
(80-82) \\
20-C C \\
\end{array}$ & & & & & & & & & $\begin{array}{c}24-2 \\
(20-22) \\
24-C C \\
25-1 \\
(80-82) \\
26-C C \\
\end{array}$ & \\
\hline
\end{tabular}

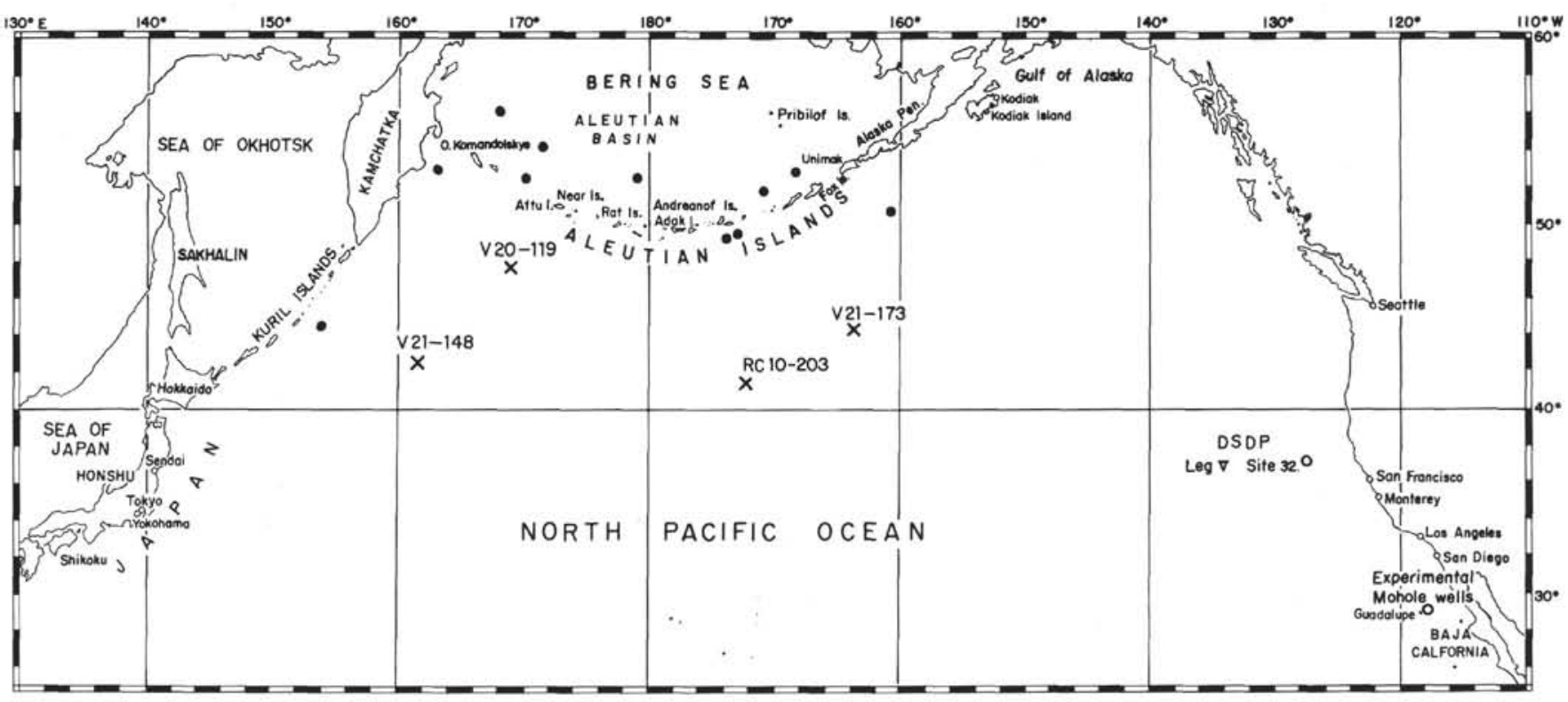

Figure 5. Location map of sediment cores in the North Pacific Ocean and of the circum-North Pacific regions used in this study. Black points indicate the positions of sites of Leg 19, Deep Sea Drilling Project.

Denticula seminae Partial-range-zone (Donahue, 1970)

Definition: The zone is defined by the fact that the occurrence of Denticula seminae is subsequent to the extinction of the Rhizosolenia curvirostris.

Remarks: This zone includes the taxa which form the subarctic assemblage or northwest marginal assemblage of Kanaya and Koizumi (1966).

A tabulation of the zones for all of the samples studied here is presented for each site in Table 12 .

\section{CORRELATION WITH OTHER PACIFIC AREAS AND AGE ASSIGNMENTS FOR THE DIATOM ZONES IN THIS STUDY}

In order to know the extent of the applicability of the diatom biostratigraphic zonation and the age assignments of the diatom zones developed above, it was attempted to correlate the sediments at each site of Leg 19 with those from other North Pacific areas (Figures 5, 8, and 9): deep-sea cores from the North Pacific (Donahue, 1970; 


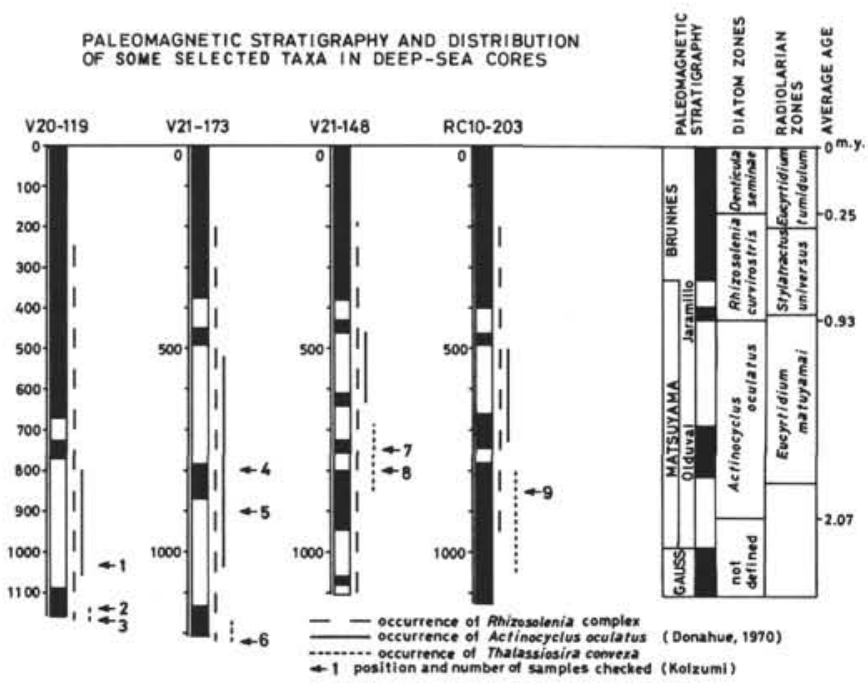

Figure 6. Paleomagnetic stratigraphy and distribution of selected diatom species in deep-sea cores from the North Pacific (after Donahue, 1970). Samples in the lower part of the cores were checked in this study by Koizumi.

Jousé 1971a); drilling core at Site 32, off San Francisco, Leg 5, Deep Sea Drilling Project; experimental Mohole drillings (Kanaya, 1971); and nearshore marine sediments cropping out in the Soviet Far East (SheshukovaPoretzkaya, 1967, 1968) and Japan (Koizumi, in press).

Deep-sea Cores From North Pacific (with Figures 6 and 7 and Table 13)

The scheme of the deep-sea Quaternary stratigraphy of the North Pacific, which has been carried out by Jouséand her collaborators, was based mostly on diatom records in deep-sea cores. Using three types of diatom variation (quantitative, ecological, and phylogenetic) observed in the cores, Jousé (1961b, 1962, 1963, 1969, and 1971a) has subdivided the core sequences into stratigraphic horizons which represent alternately interglacial and glacial periods, with odd numbers representing interglacials and even numbers glacials, during the Quaternary. The oldest Quaternary horizon, which represents the initial cooling at the beginning of the Pleistocene, was identified as Horizon VIII by Jousé (1969), for example, at the level $629-767 \mathrm{~cm}$ in core V20-119. Later, Jousé (1971a) corrected this horizon VIII to Horizon VIA. According to Ninkovich et al. (1966), this part corresponds to the uppermost part of the Matuyama Reversed epoch, between 0.70-0.93 million years B. P., and is, as in Hays and Berggren (1971), not the beginning of the Pleistocene. In the left column of Figure 7 some comments by Koizumi are given.

Paleomagnetic stratigraphy, combined with the biostratigraphic datum and zones, provides a time scale for the Quaternary and younger Tertiary stratigraphy of deep-sea sediments (e.g., Hays and Opdyke, 1967; Hays et al., 1969).
Donahue (1970) defined diatom stratigraphic zones and also constructed relative paleotemperature curves based on deep-sea cores from the North Pacific, using a chronostratigraphic framework based upon paleomagnetic stratigraphy and on other siliceous microfossils. Three stratigraphic zones in ascending order, the Actinocyclus oculatus, Rhizosolenia curvirostris, and Denticula seminae zones, by Donahue (1970) are followed, except at the base of the oldest zone, since it became clear during this study that they are applicable to the sequences of Leg 19. Figure 6, with some modification by Koizumi, shows stratigraphic ranges of indicator species with the paleomagnetic scale in each core, and a comparison of paleomagnetic, diatom, and radiolarian zones. Since the oldest sediments examined were not zoned by Donahue (1970), Koizumi checked diatom distribution in nine samples from the neighborhood of the Olduvai event in several deep-sea cores. Table 13 shows the results of this observation, with the column on the bottom indicating the correlative zonal names. Both Denticula seminae and Denticula kamtschatica are recog. nized only in the oldest zone, and they are the index species which define the Denticula seminae-Denticula kamtschatica Zone in this study. Still, the Thalassiosira zabelinae Zone was not confirmed, which may be because this zone is very thin or is limited in geographic distribution.

\section{Drilling Core at Site 32 (off San Francisco), Leg 5, Deep Sea Drilling Project (with Table 14)}

Samples of deep-sea sediments from Site 32 of Leg 5 are suitable for investigating, in connection with the diatom zonation in this study, the younger Tertiary diatom stratigraphy in the eastern North Pacific. Samples were available from Cores 3 through 8 , and many of them were barren of calcareous microfossils. Age designation of these samples by the shipboard scientific party (McManus, Burns et al., 1970) is as follows: the upper Pliocene Discoaster brouweri Zone is represented by Core 3, and the lower Pliocene Ceratolithus rugosus-Reticulofenestra pseudoumbilica Zone by Cores 4 and 5 . Cores 6 and 7 represent the upper Miocene Ceratolithus tricorniculatus Zone, and Core 8 represents the middle Micoene Discoaster exilisReticulofenestra pseudoumbilica Subzone, except for Section 1, which includes the upper Miocene Discoaster variabilis Zone. Table 14 shows the frequencies of each taxon which was identified by counting fifty to one hundred specimens in the drilled cores at this Site 32, and the right-hand column "diatom zone" indicates the corresponding zonal names with the diatom zonation in the Leg 19 sequences. The vertical distribution of each species of the genus Denticula Kütz., from all of the samples, coincides with that in the Leg 19 sequences. In the Thalassiosira zabelinae Zone, however, the presence or continuous occurrences of some characteristic species are not recognized, especially Coscinodiscus pustulatus, Stephanopyxis horridus, and Thalassiosira zabelinae. It may be because of rough counting of valves. 


\section{Drilling Core From the Experimental Mohole Drillings (Guadalupe Site)}

Diatoms from the experimental Mohole drillings were subdivided into four zones, numbered from I to IV in ascending order, by Kanaya (1971). These zones were correlated with California stages, especially by the use of the relationship between Denticula lauta and Denticula hustedtii. Kanaya (1971) states that it appears tenable to correlate zone I broadly with the Luisian, zone II with the lower Mohnian, zone III with the upper Mohnian, and zone IV with the Delmontian Stage of California. The lower part of zone III extends to the lower Mohnian Stage. Judging from the stratigraphic distribution of the species of Denticula in the chart (Kanaya, 1971, Figure 40.1), it appears that the boundary between the Denticula lauta Zone and the Denticula hustedtii Zone defined in this study occurs in the middle part of zone III, between EM8-11, $17-20 \mathrm{~cm}$ and EM8-10, $77-80 \mathrm{~cm}$, which is correlative with the upper Mohnian Stage.

Potassium-argon dating was applied to three samples from the drillings by Dymond (1966). An age of 4.3 million years B.P. was determined for sample EM9-1, $46 \mathrm{~cm} ; 11.4$ million years B.P. for sample EM8-13, $133 \mathrm{~cm}$, and 12.3 million years B.P. for EM8-15, $89 \mathrm{~cm}$. Judging from these data, the boundary between the Denticula lauta Zone and Denticula hustedtii Zone may be dated at about 9 to 10 m.y. ago.

\section{Neogene Deposits in the Soviet Far East (Figure 8)}

Marine Neogene deposits are extensively developed in the Far East. Among them, diatomaceous rocks are common. The works on Neogene diatoms of Kamchatka and Sakhalin have shown a tendency toward systematic description and stratigraphy. Jousé (1959, 1961, 1962) outlined the evolution of the far eastern marine diatoms beginning with the late Miocene and described the new species. According to the recent works by SheshukovaPoretzkaya $(1967,1968)$, it is possible to identify the five stratigraphical stages in the development of the far eastern marine diatoms in the Tertiary:

1) The oldest marine diatoms, in the lower course of the Anadyr River, can be dated broadly as late Eocene to Oligocene. The diatoms are quite peculiar, and nothing like them are reported either from the USSR or other areas.

2) The next stage is tentatively dated as middle Miocene. The diatoms of this stage occur at the base of the Diatomite, Schmidt Peninsula. It is characterized by the occurrences of Actinocyclus ingens, Denticula lauta, Goniothecium tenue, Kisseleviella carina, and Mediaria splendida. Based upon the occurrences of these species, this stage is correlated with the Denticula lauta Zone in the Leg 19 sequences.

3) The late Miocene diatoms differ from the middle Miocene diatoms. The former include a diversity of species of genus Thalassiosira C1.; Thalassiosira antiqua, Thalassiosira nidulus, Thalassiosira usatschevii, and Thalassiosira zabelinae appear first. They are accompanied by Cosmiodiscus insignis, Cosmiodiscus intersectus, and Rouxia peragalli forma californica, while typical species of the middle
Miocene disappear. They are identified in the Diatomite and the Mayamraf Formation of the Schmidt Peninsula, and the Maruyama Formation of southern Sakhalin. Mass occurrence of Denticula hustedtii is recognized in the Diatomite, Schmidt Peninsula, which is dated as the lower part of the late Miocene. In addition to this, the diatom assemblage in the Tyushevsk Formation of Kamchatka is abundant in both Thalassiosira zabelinae and Denticula kamtschatica. It appears that the lower part of this stage is correlated with the Denticula hustedtii Zone, and the upper part with the Denticula kamtschatica Zone in the Leg 19 sequences by the similarity of the composition and features in the floral changes.

4) A diatom assemblage, including Denticula seminae, Melosira albicans, and Thalassiosira gravida forma fossilis, was identified in the unconsolidated deposits of the Ust-Kamchatka area. This proves that the deposits of Kamchatka in this stage are not older than Pliocene. The diatoms are quite different from the Miocene diatoms of Sakhalin and Kamchatka and are characterized not only by the disappearance of many characteristic Miocene species, but also by the vigorous development of the younger, still living forms. These distinctive features are suggestive of the possibility of comparison between this stage and the Denticula seminae-Denticula kamtschatica Zone in Leg 19 sequences.

5) The Pliocene diatoms, in the Etolon Formation, northwestern Kamchatka, are a shallow-water type. Marine benthonic diatoms of Pennate form are numerous. Jousé $(1959,1962)$ also states that the boundary between the Miocene and Pliocene diatoms is marked by a mass appearance of Thalassiosira and Stephanopyxis, with the bulk of them preserved as spores in diatomaceous earth. These features are broadly compared with the Thalassiosira zabelinae Zone in the Leg 19 sequences. The definition of the upper Pliocene and the Plio-Pleistocene boundary by Soviet workers both on land-based sequences (e.g. Jousé, 1959, 1962) and in deep-sea core sections (e.g. Jousé 1969,1971 a) is still open to discussion.

Fossil diatoms of the Kurile Islands have been studied by Jousé $(1959,1962)$ and Vergunov (1968) and subdivided into three assemblages; middle Miocene, Pliocene, and middle Pleistocene.

Neogene Deposits in Japan (with Figures 9 and 10 and Table 15)

The preliminary results of studies in progress on the younger Cenozoic diatom biostratigraphy in the northern circum-Pacific region were given by Kanaya and Koizumi (1970). In the study, a total of 134 diatom species were chosen and their stratigraphic ranges were determined. The determination of local ranges in Japan was reexamined based on the stratigraphically controlled diatomaceous samples from various areas of Japan as shown in the index map (Figure 9) by Koizumi (in press). The chronostratigraphic framework was prepared after Kanaya and Koizumi (1970) and Ikebe et al. (1972). The locating of radialarian 


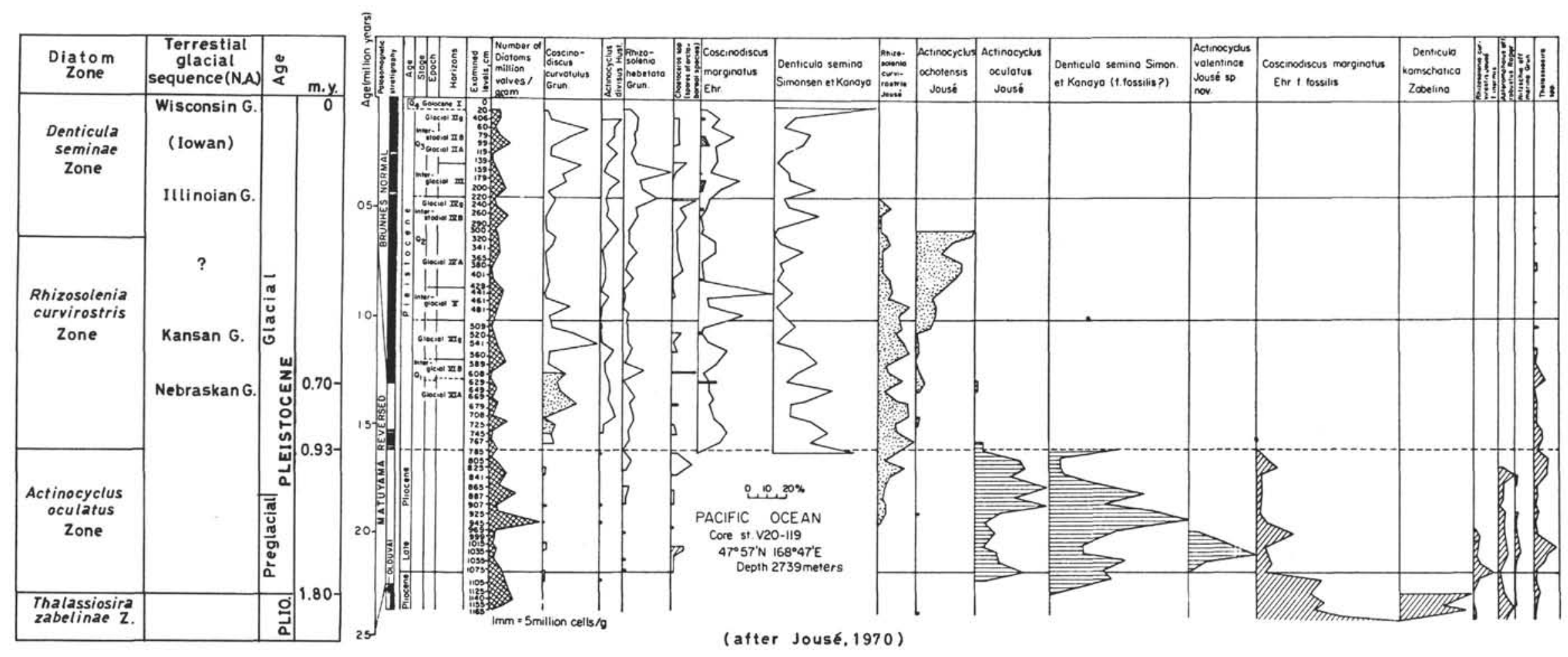

Figure 7. Comparison of the geologic age assignments by Jousé (1970) for deep-sea core V20-119 with paleomagnetic stratigraphy. Koizumi has checked the former. 
TABLE 13

Distribution of Marine Planktonic Diatoms and Diatom Zones in the Selected Samples from the Neighborhood of the Olduvai Event. A.o.: Actinocyclus oculatus, Th. z.: Thalassiosira zabelinae

\begin{tabular}{|c|c|c|c|c|c|c|c|c|c|}
\hline \multirow{3}{*}{$\begin{array}{rr}\text { SAMPLES } & \text { CORE NUMBER } \\
\text { LEVEL OF SAMPLE }(\mathrm{cm}) \\
\text { SPECIES } \\
\text { SAMPLE NUMBER }\end{array}$} & \multicolumn{3}{|c|}{ V 20-119 } & \multicolumn{3}{|c|}{ V $21-173$} & \multicolumn{2}{|c|}{ V21-148 } & \multirow{2}{*}{\begin{tabular}{|c|}
$R C 10$ \\
203 \\
850
\end{tabular}} \\
\hline & 1035 & 1140 & 1170 & 800 & 900 & 1218 & 750 & 800 & \\
\hline & 1 & 2 & 3 & 4 & 5 & 6 & 7 & 8 & 9 \\
\hline Actinocyclus curvatulus & & & & & & & & & 2 \\
\hline A. divisus & & & & & 1 & & & 1 & 2 \\
\hline A. ochotensis & 24 & 1 & & & & & & & \\
\hline A. oculatus & 37 & & 1 & 46 & 49 & & & & \\
\hline Coscinodiscus excentricus & 2 & 1 & & & & & 2 & 4 & \\
\hline C. marginatus & 5 & 18 & 29 & 5 & & 59 & 16 & 16 & 28 \\
\hline c. marginatus $t$. & & & 11 & & & 9 & 1 & & \\
\hline c. nodulifer & & & & & & & 2 & 8 & 3 \\
\hline c. radiatus y. & & & & & & & 2 & 1 & 2 \\
\hline c. sterallalis & & & & & & & 2 & 5 & \\
\hline c. tabularis & & & & & & & & & 2 \\
\hline Denticula kamtschatica & & 50 & 30 & & & 12 & 1 & 4 & 1 \\
\hline D. seminae & 26 & 32 & 22 & 41 & 24 & 13 & 1 & 2 & 10 \\
\hline Hemidiscus cuneiformis & & & & 1 & & 1 & 19 & 16 & 15 \\
\hline Nitzschia fossilis & & & & & & & 2 & & 10 \\
\hline N. jousei & & & & & & & 1 & & \\
\hline N. marina & & & & & & & 4 & 6 & 2 \\
\hline N. reinholdii & & & & & & & 3 & 7 & 8 \\
\hline Pseudoeunotia doliolus & & & & & & & 1 & & \\
\hline Rhizosolenia curvirostris $t$. & 5 & & 3 & 1 & 9 & 2 & 5 & & 6 \\
\hline Thalassionema nitzschioides & & & & & & & 31 & 21 & 4 \\
\hline Thalassiosira antiqua & & & & & & & & 1 & \\
\hline T. convexa & & & & & & 1 & 1 & 3 & 1 \\
\hline r. decipiens & & & 2 & & & & & 2 & \\
\hline T. gravida & & & & & 7 & 1 & & & \\
\hline oestrupi & & & & 1 & 2 & 3 & 6 & 1 & 4 \\
\hline T. zabelinae & 1 & & & & & & & 1 & \\
\hline sp. & & & & & 6 & & & & \\
\hline Thalassiothrix longissima & & & & 5 & 4 & 1 & & & \\
\hline DIATOM ZONE & A.0. & & $z^{b}$ & & $1.0^{0}$ & Th. z $^{\mathrm{b}}$ & & $z^{b}$ & Th.z. \\
\hline
\end{tabular}

A. o. - Actinecyclus oculatus.

'Th. z,-Thalossiosiro zobelinae.

zones into the framework is after Nakaseko et al. (1972b) based on the comparison with planktonic foraminiferal zones. The diatomaceous samples were stratigraphically located into the framework by the following means: first, planktonic foraminiferal zonation by Saito (1963) and Shinbo and Maiya (1969); second, radialarian zonation by Nakaseko (1959, 1960) and Nakaseko et al. (1972); and third, by significant megafossil data such as mollusca and plants (Table 15). Figure 10 indicates the chronostratigraphic ranges of selected species compiled from the various areas of Japan and the tentative subdivision into six diatom zones. It is found that a considerable similarity exists in diatom zonation between Japanese land sections and Leg 19 sequences in the high latitude of the North Pacific.

The Denticula lauta Zone in Leg 19 sequences is correlated with the upper part of the Denticula lauta-Denticula hustedtii Zone in Japan, which is dated as the upper part of the middle Miocene. Two zones, the Denticula hustedtii and Denticula kamtschatica zones, in Leg 19 are correlated respectively with the same named zones which occupy the late Miocene in Japan. The Denticula seminae-Denticula kamtschatica Zone is also correlated with the same named zone in the early Pliocene of Japan. Diatom zonation on the land sections of Pliocene age, especially in its late stage in Japan, is not clear, because during this time lacustrine to terrestrial deposits are rather common in many parts of Japan.

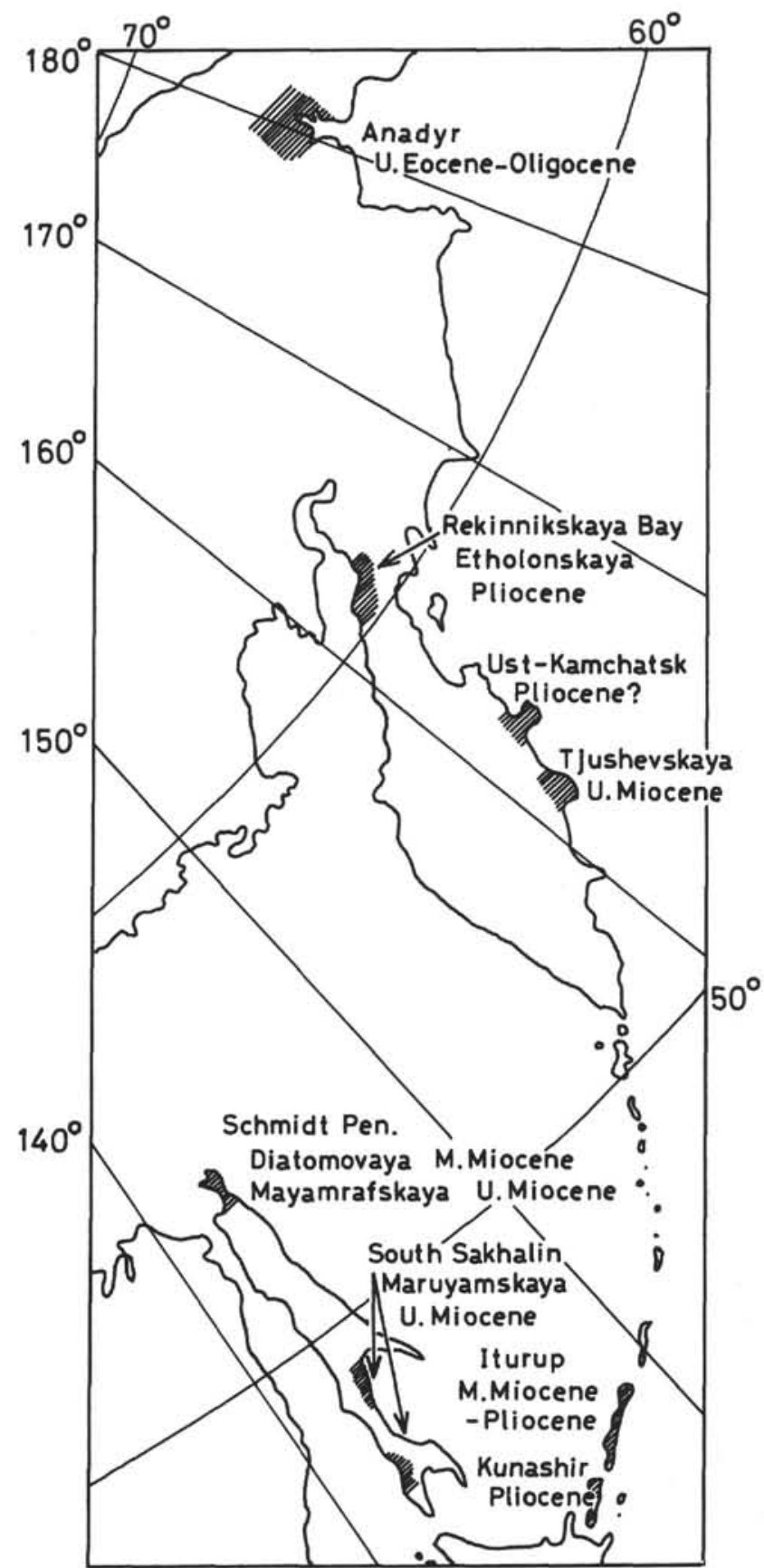

Figure 8. Index map of location and geologic age of the important diatomaceous strata in the Soviet Far East.

In the Abashiri-Urahoro area, east Hokkaido, the diatoms have been studied by Sawamura and Yamaguchi (1961, 1963). The lower horizon, group A, from the Tsubetsu Group in this area is characterized by the usual occurrence of Kisseleviella carina, and the upper group B from the Kamisato Group by the appearances of Actinocyclus ingens, Coscinociscus elegans, Denticula spp., Stephanopyxis schenckii, and Rouxia peragalli. Group A may indicate the middle Miocene, and Group B the late Miocene on the basis of diatoms. The correlation between 


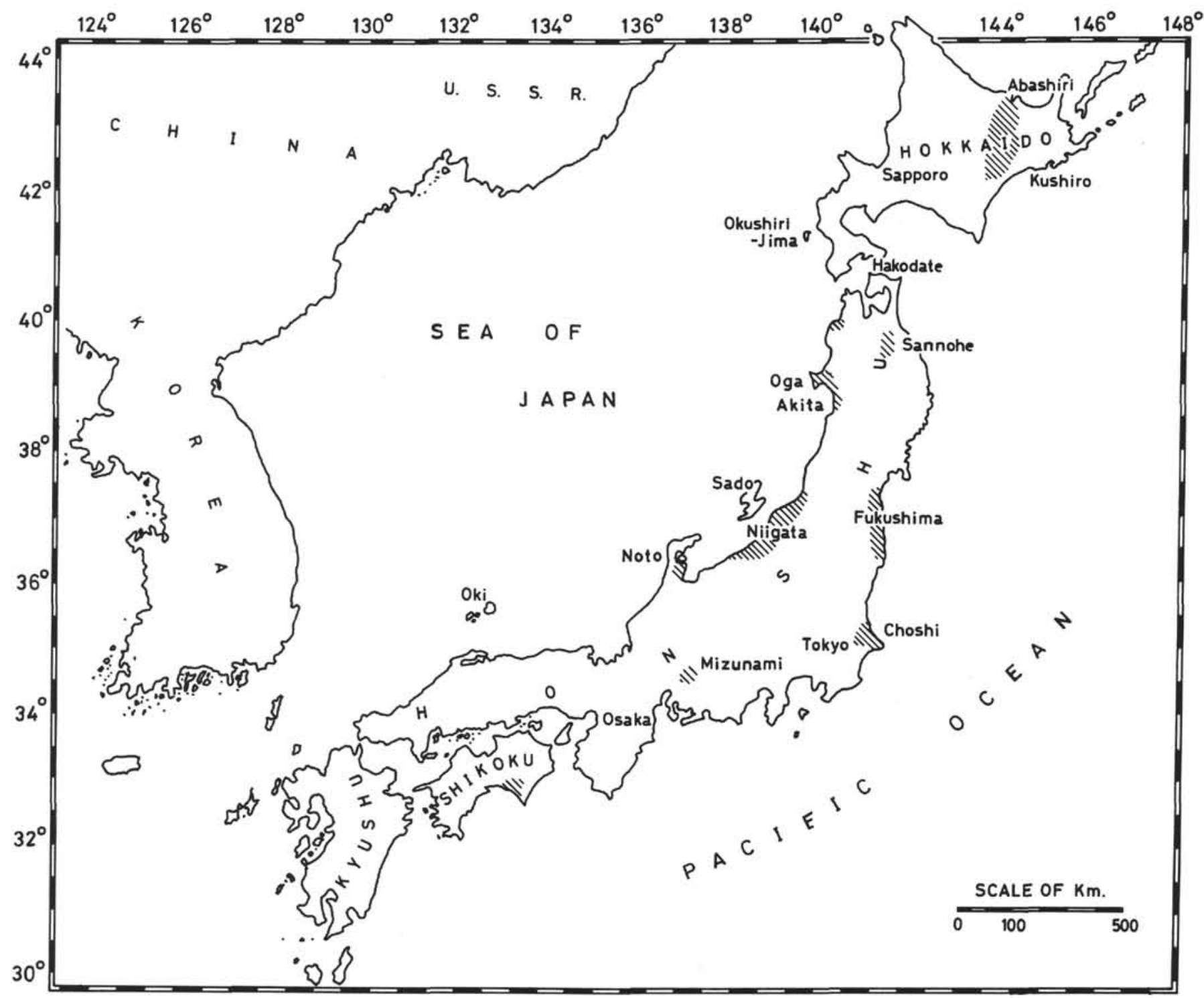

Figure 9. Index map of selected Neogene diatomaceous sequences in Japan.

the group and each diatom zone defined in Honshu is a problem left for future study.

\section{Age Assignments For the Diatom Zones in This Study}

The correlations with the dated deep-sea cores and land sections made it possible to determine the geologic age of diatom zones represented by diatom-bearing samples from cores at Sites 183 through 193 of Leg 19, as explained in Figures 4 and 13 and Tables 1-11 prepared for each site.

\section{PALEOENVIRONMENTAL INTERPRETATIONS}

All ecological analyses of fossil materials depend upon the behavior of living species in the assemblage, assuming that the ecological adjustment of organisms was essentially similar during past geological epochs. The older its geologic age, the smaller the percentage of living species in an assemblage is expected to be (Kanaya, 1957). This statement holds true for the paleoecological analyses of the present material. As shown in the tables for each site, it is desirable to limit the application of the paleoecological analyses to only the Quaternary part of the Leg 19 sequences because most of the taxa identified in the samples below the Thalassiosira zabelinae Zone to the Denticula seminae-Denticula kamtschatica Zone, dated Pliocene, are extinct and have very few living counterparts.

\section{Paleoclimatic Interpretations (with Figure 11)}

The distribution of diatoms in modern sediments, as described from the upper layers of deep-sea cores by Jouse (1962), Kanaya and Koizumi (1966), and Jousé et al. $(1969,1971)$, has shown a pattern that is best explained by the areal distribution of the upper water masses, in turn governed by the climatological and circulatory regimes of the Pacific Ocean. Diatoms, therefore, are reliable ecologic indicators and useful for paleoclimatic interpretation of the fossil material. 


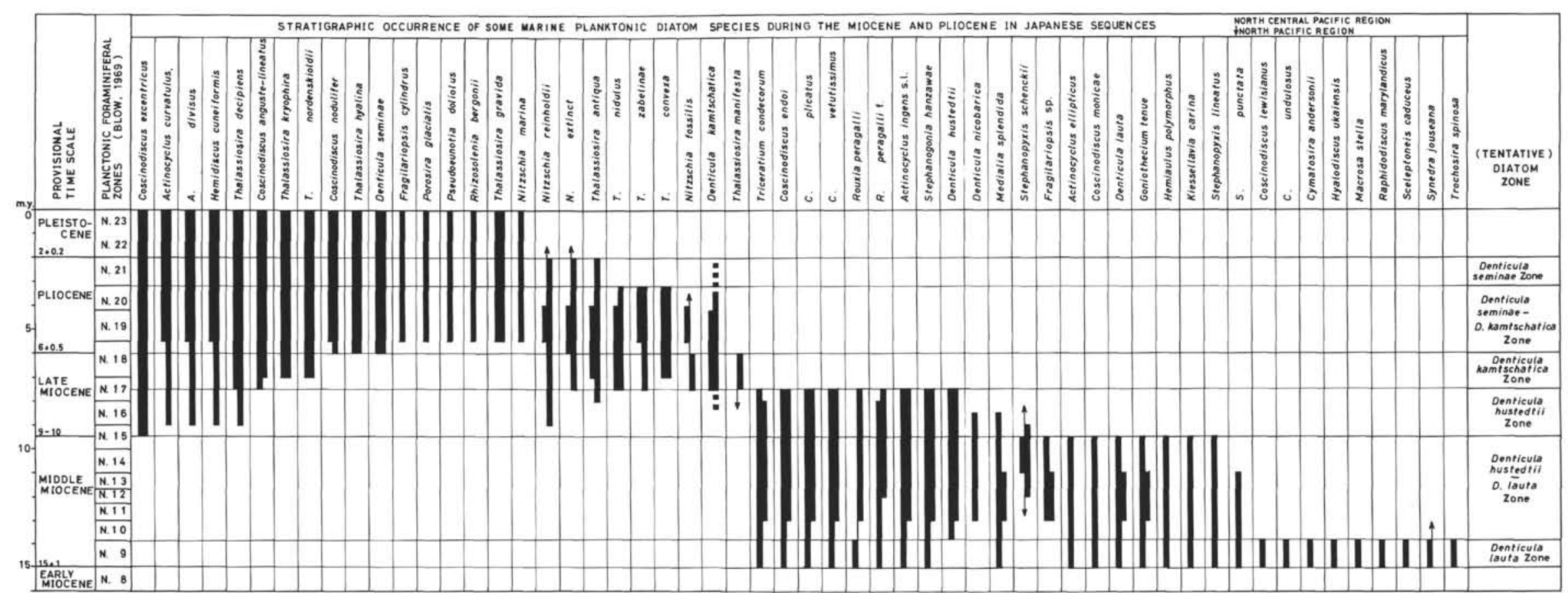

Figure 10. Stratigraphic ranges of selected marine planktonic diatoms and tentative zonal subdivision during the Miocene and Pliocene in Japan (Koizumi, in press). 
TABLE 14

Zonal Subdivision and Distribution of Marine Planktonic Diatoms in Site 32 (Off California), Leg 5, Deep Sea Drilling Project

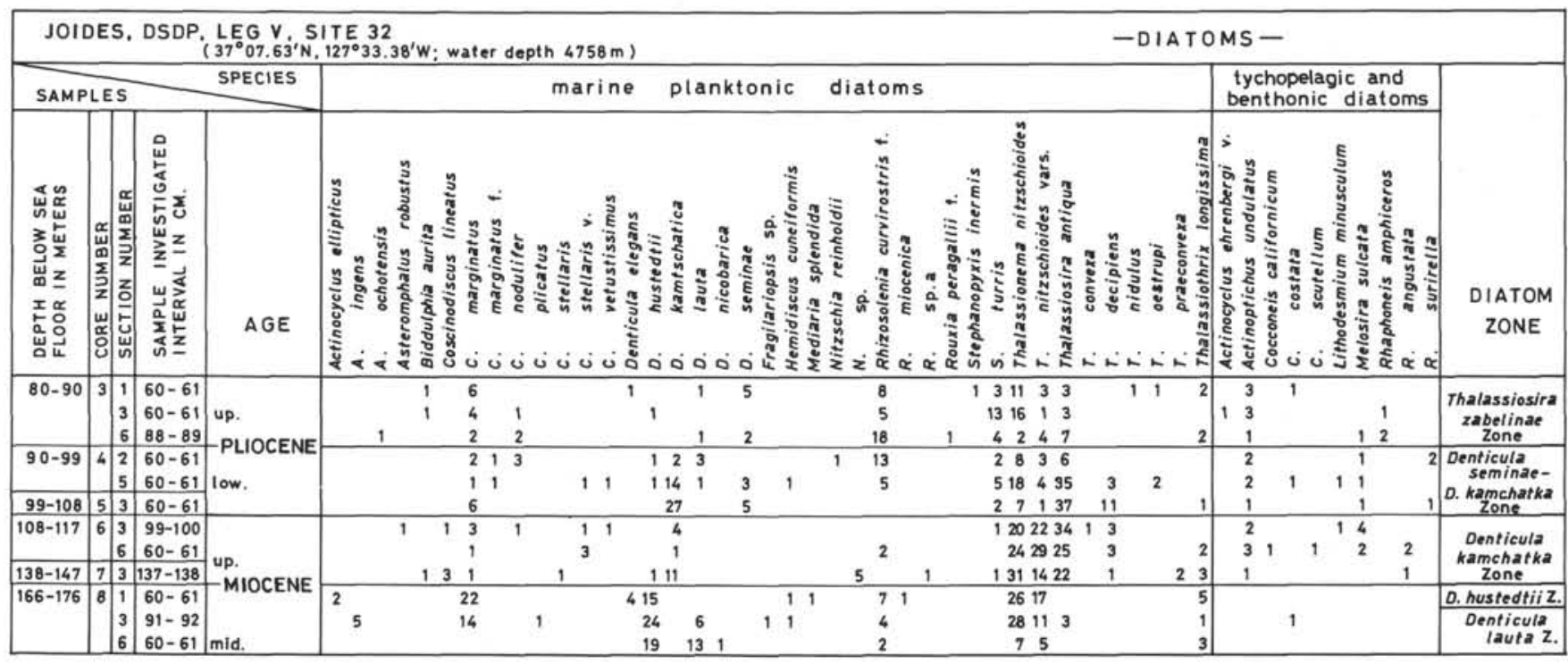

TABLE 15

Stratigraphic Positions of Diatomaceous Strata Studied in Koizumi (1972b)

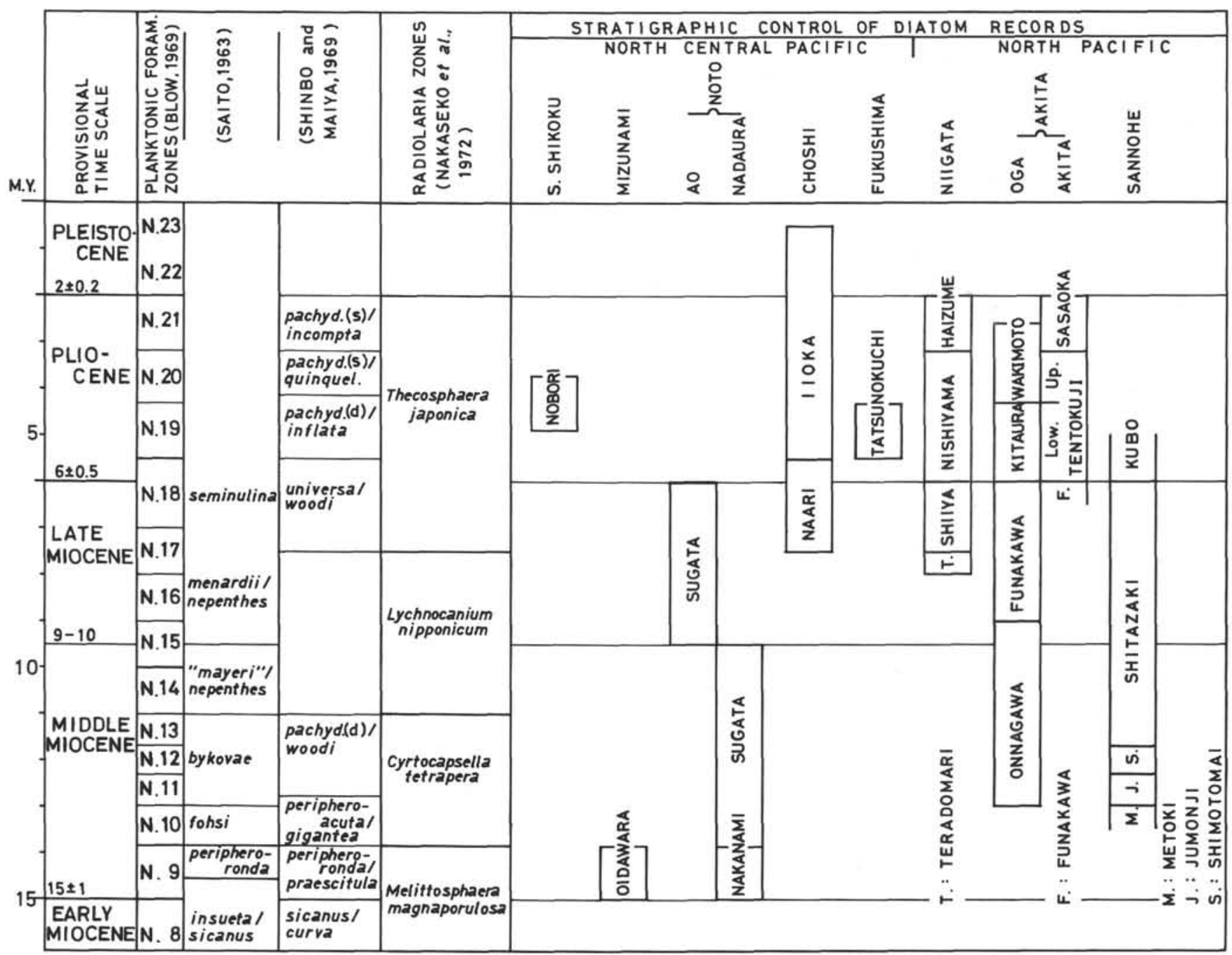




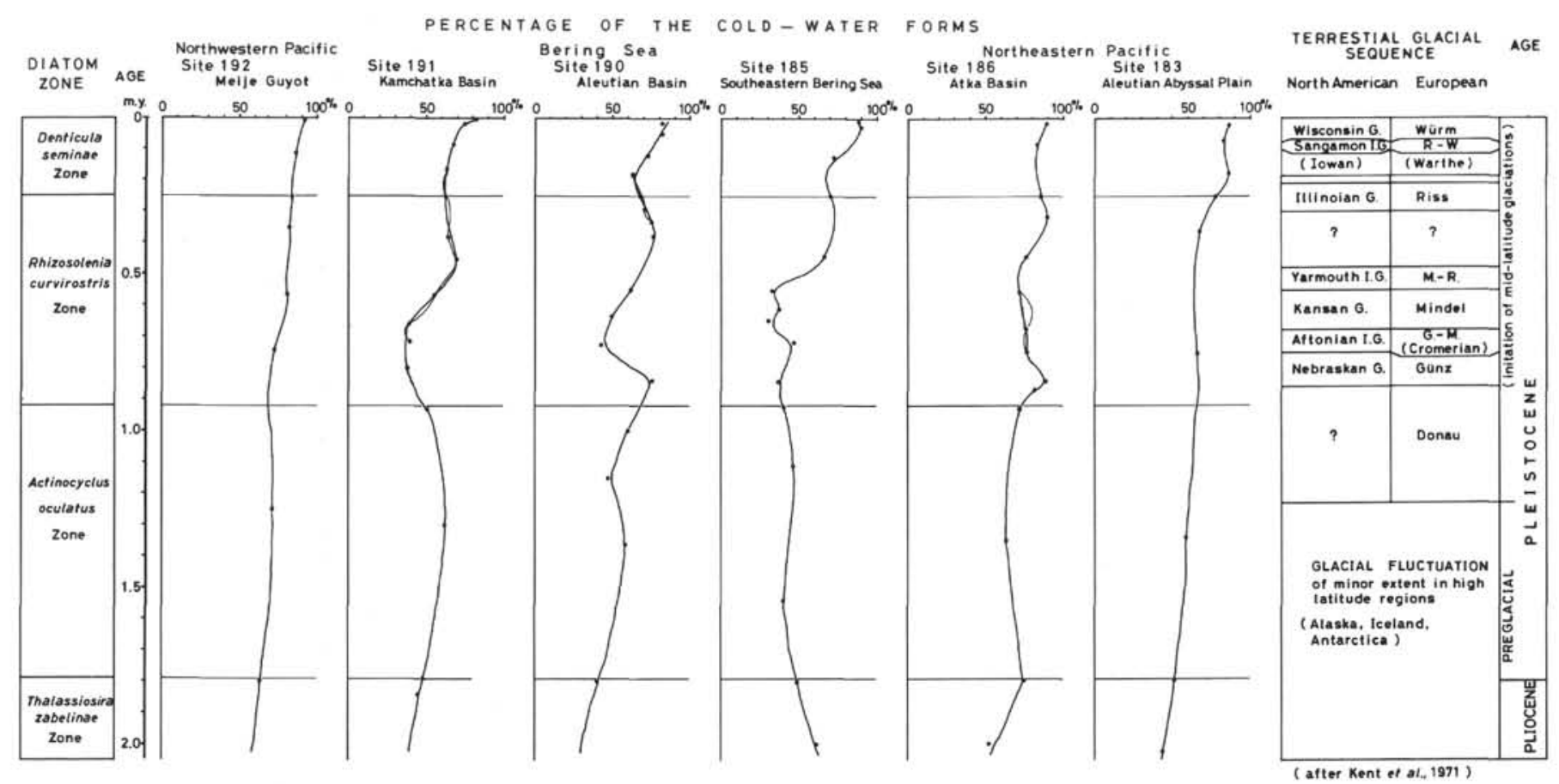

Figure 11. Comparison of terrestrial glacial sequences recognized in the ice-rafting curve from the North Pacific (Kent et al., 1971) with the climatic fluctuations, based on the percentage of the cold-water diatoms from selected sites, Leg 19, Deep Sea Drilling Project.

A diatom temperature value (Td), which was proposed. by Kanaya and Koizumi (1966), could not be used in this study because the occurrences of the warm-water diatoms (Xw) were not observed throughout Quaternary samples, except for very rare occurrences at Site 193. Figure 11 shows the generalized temperature curve based upon the percentage of cold-water diatoms in the Quaternary section of six sites plotted against a uniform time scale. The cold-water forms, indicated by the letter $C$ in the column Group II and IV of each table (Tables 1-11), are those taxa that are common in the sediments underlying the subarctic water masses. Group II is composed of planktonic diatoms, dominantly oceanic, of the boreal zone of the North Pacific occupied by subarctic waters, and Group IV is made up exclusively of arctic and arcto-boreal planktonic species, which consist of neritic species only. Six sites were selected among various areas covered by the Leg 19 cruise.

From the bottom to the top of the Quaternary section at all of the sites, the cold-water forms are dominant. Fluctuations in the percentage curve are more remarkable in the upper sections than in the lower sections of these sites. This can be well observed in the section at Site 190 from the Aleutian Basin, Bering Sea, and Sites 1.83 and 186 from the northeastern Pacific. The transition from monotonous to various on the percentage curve is at about $1.2 \mathrm{~m} . \mathrm{y}$. ago, in the upper part of the Actinocyclus oculatus Zone. Each curve has the three major maxima in the percentage curve accompanying two minima in the upper sections (post 1.2 m.y. ago). First, the lowest maximum occurs at about 0.85 m.y. ago in the lower part of the Rhizosolenia curvirostris Zone, the second about $035 \mathrm{~m}$.y. ago in the uppermost part of the same zone. The third maximum, the highest, is found in the uppermost of the Denticula seminae Zone. In the sections at Sites 183 and 186 a minor maximum, which is not apparent in Site 190, occurs at about 0.6 m.y. ago in the middle part of the Rhizosolenia curvirostris Zone. On the other hand, two minima are recognized at about $0.7 \mathrm{~m} . \mathrm{y}$. and $0.2 \mathrm{~m}$.y. ago. These major maxima in the percentage curve can be correlated through almost all the sites, but the fluctuations were not recognized at Sites 185 and 192. This may be because the details of the fluctuations were masked in the curve. It seems reasonable to assume that higher percentages of cold-water forms correspond to periods of glaciation, and lower percentages to interglacial periods.

Jousé $(1961 b, 1962,1963,1969,1971$ a) has defined eight horizons largely on the basis of relative abundance of warm- and cold-water species, and marks the oldest horizon VIII as the initial cooling at the beginning of the Pleistocene. Donahue (1970) shows two major divisions with the Quaternary based on the diatom temperature (Td) values in deep-sea cores from the North Pacific; one from $2.0 \mathrm{~m} . \mathrm{y}$. ago to $0.7 \mathrm{~m} . \mathrm{y}$. ago, a time of relatively stable Td values; the other from $0.7 \mathrm{~m}$.y. ago to the present, a time of lower average $\mathrm{Td}$ value than in the former interval and showing greater fluctuation in the Td curves. Recently, Kent et al. (1971) gave particulars on the climatic changes in the North Pacific using ice-rafted detritus (the weight 


\section{A G E ( $10^{6}$ years, a fter I kebe et al., 1972)}

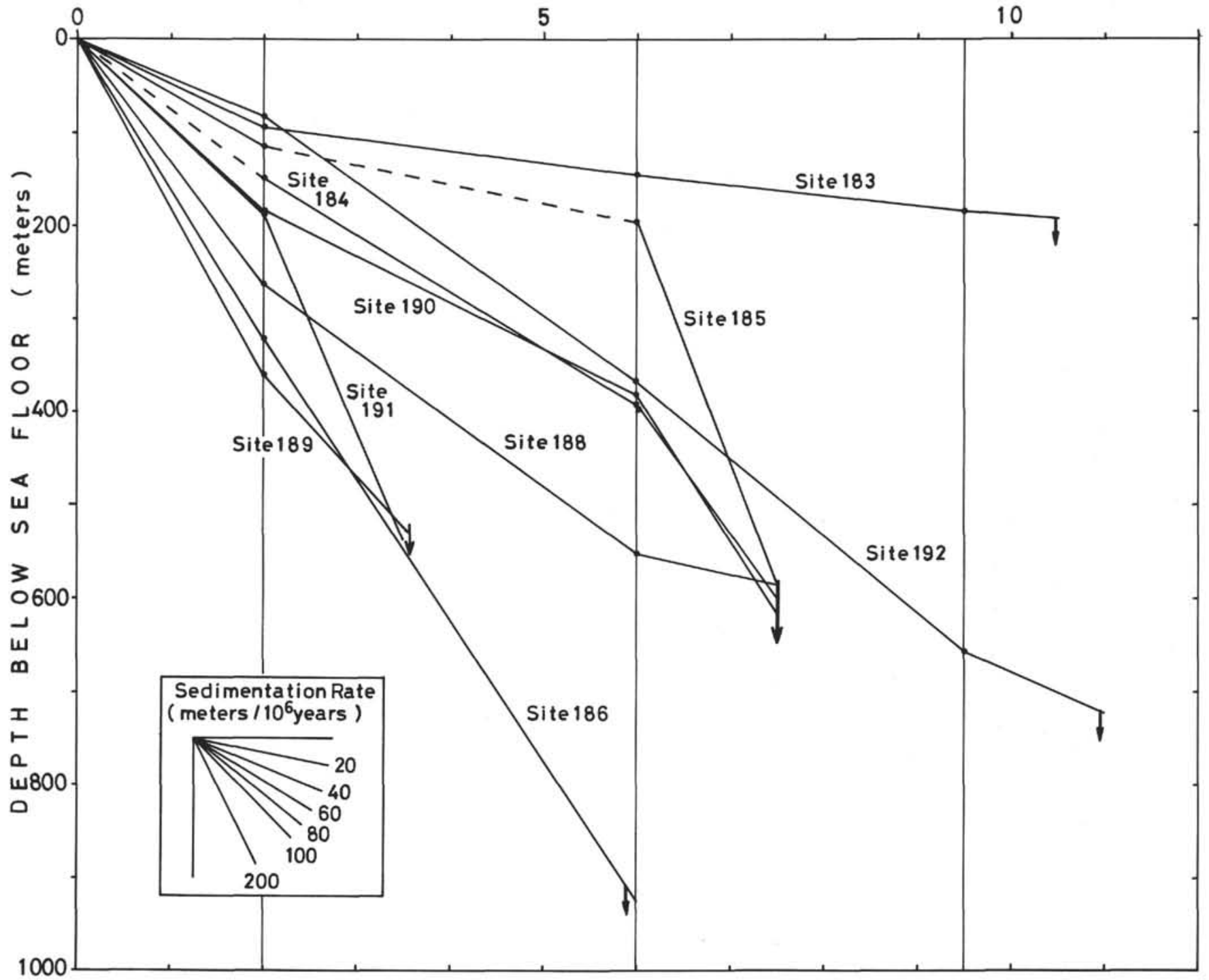

Figure 12. Sedimentation rates at various sites, Leg 19, Deep Sea Drilling Project, based on diatom zoning.

percentage of the "glacial" fraction greater than $250 \mu$ ) in nine deep-sea cores from the North Pacific, based upon the results of paleomagnetic stratigraphy, tephrachronology, and micropaleontology.

The left-hand side of Figure 11 indicates the correlation with Kent et al. (1971). Their conclusions coincide with the generalized result of this study. For the reason stated above, if the subdivisions of Jousé (e.g., 1969, 1971a) are chronologically corrected as indicated in the left-hand side of Figure 7, the results by Jouse also coincide with those in this study. Namely, (a) the increase in the percentage of the cold-water diatoms is beginning from about $1.8 \mathrm{~m} . \mathrm{y}$. ago to the present. (b) No change in the percentage curve of the cold-water diatoms occurs until 1.8 m.y. ago, the level of the Plio-Pleistocene boundary, but a significant change occurs at about 1.2 m.y. ago. Therefore, the Pleistocene section can be divided into preglacial and glacial parts as stated in Hays and Berggren (1971). (c) Three major and one minor maxima in each percentage curve are recognized. They may suggest periods of more intense glaciation and coincide with more extensive glaciation on the continents. Among them the first maximum occurs at about 0.85 m.y. ago, which indicates the global cooling and marks the initiation of mid-latitude glaciation (Kent et al., 1971).

\section{Paleosedimentological Interpretations}

All of the younger Cenozoic sequences cored at every site on Leg 19 appear to have normal arcto-boreal marine diatom assemblages despite the occurrences of fresh-water and benthonic to sublittoral nearshore diatoms in the Pleistocene and upper Pliocene of Sites 185, 189, 190, and 191 from the Bering Sea. These freshwater and benthonic 


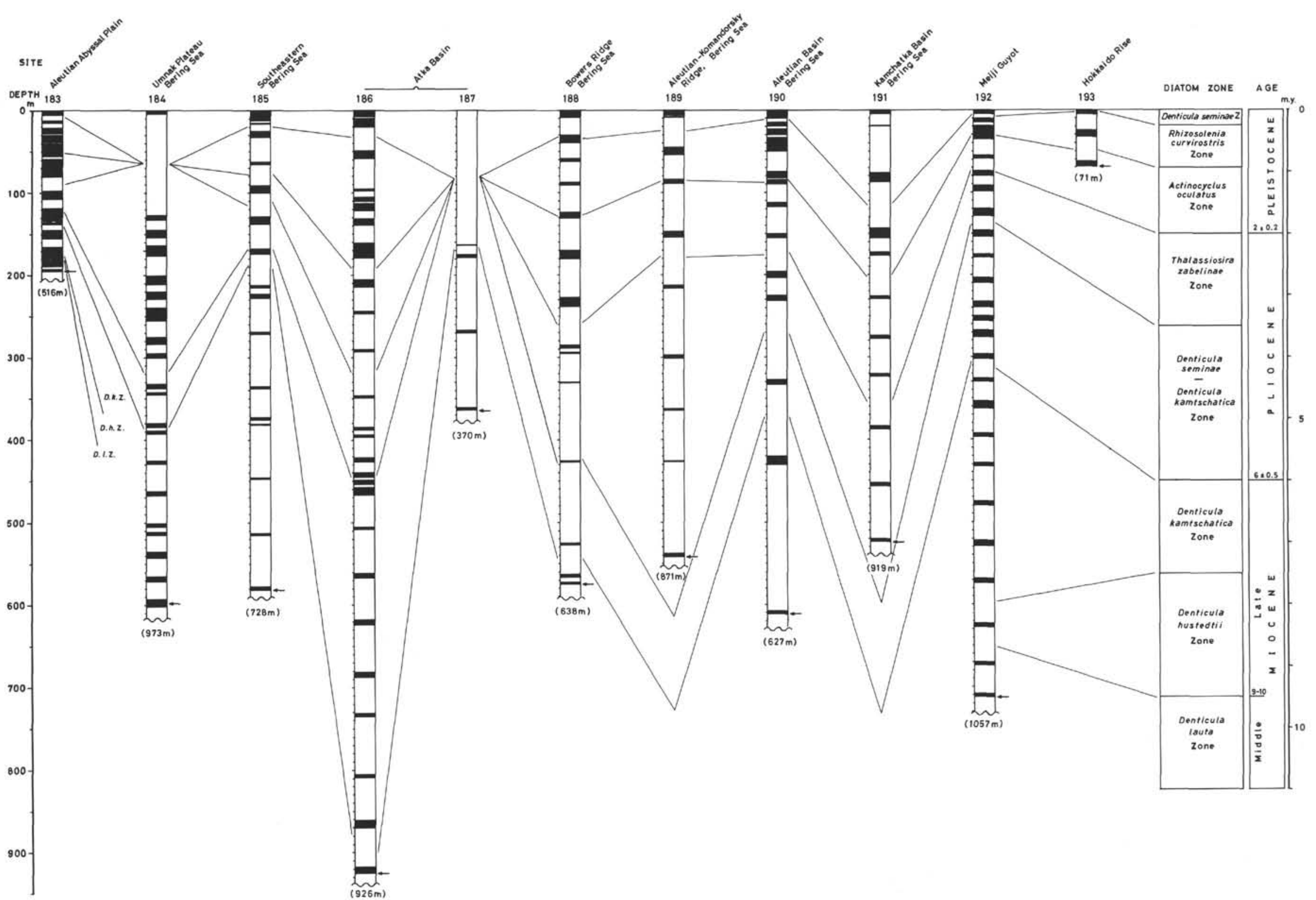

Figure 13. Comparison of thickness of the diatom zone at each site, Leg 19, Deep Sea Drilling Project, Black areas represent recovered sequences. No diatom valves were observed below the level pointed by the arrows. Figures in parentheses indicate the level of penetration at each site. 
diatoms, foreign to the living populations in the basin, were presumably transported to the marine sedimentary environment by drainage from the land and by subaqueous agencies from older sediments during the time. Namely, as suggested by the greater amount of terrigenous materials, the occurrences of displaced freshwater and benthonic diatoms at Sites 185 (Table 3) and 189 (Table 7) may be explained by the closer proximity to the Alaska mainland and Bering Sea shelf, and the Aleutian Ridge. Reworked fossils, displaced freshwater and benthonic diatoms, displaced benthonic foraminifera, and several layers of sizegraded sands and silts in the upper sections at Sites 190 (Table 8) and 191 (Table 9) may have been brought in by turbidity currents. This presumably means that the first significant glacial lowering of sea level occurred about 2 to 3 m.y. ago.

The extinction of the genus Stephanopyxis; Stephanopyxis horridus, Stephanopyxis inermis, Stephanopyxis turris, and genus Thalassiosira; Thalassiosira antiqua, Thalassiosira usatschevii, Thalassiosira zabelinae, both of which are indicative of a neritic environment of deposition and mark the beginning of the Pliocene age in all of the sites, is recognized in the end of the upper Pliocene in the Far East according to Jousé (1959, 1962). In Japan, these species are characteristic for the early Pliocene (Koizumi; 1972 ; in press).

\section{The Rate of Sedimentation at Each Site (with Figures 12 and 13)}

The rate of sedimentation is estimated by means of dating the sediment layers, which is rather inexact. In general, the rate is easily obtained for a given period of time from the difference in the ages of the upper and the lower boundary, and the amount of sediment in between (Koczy, 1963).

Figure 12 shows the sedimentation curves at each site and Figure 13 indicates three different regimes in the sedimentation rates. Sites 183 and 192 have "lower" sedimentation rates of about $50 \mathrm{~m} / \mathrm{m}$.y., whereas Sites 184 , 185,190 , and 191 have "middle" sedimentation rates of about 75-90 m/m.y., and the "highest" sedimentation rate was found at Sites 186, 188, and 189, about 125-175 $\mathrm{m} / \mathrm{m} . \mathrm{y}$. These sedimentation rates correlate with the relative amounts of pelagic sediments, hemipelagic sediments, and terrigenous debris-bearing sequences at each site. Namely the sequences of lower sedimentation rate are dominantly pelagic sediments, whereas the middle rates are characterized by much terrigenous debris and relatively fewer diatoms. In the case of the highest sedimentation rate, hemipelagic sediments are dominant.

\section{FLORAL REFERENCES}

References are given for those taxa from Sites 183 through 193 , Leg 19 of the Deep Sea Drilling Project. They are arranged alphabetically, separately under the marine planktonic, benthonic and tychopelagic, and freshwater diatoms. The taxa which are treated in Hustedt (1927-1964) are referred directly to Hustedt (op. cit.). As for the taxa which are not treated in Hustedt, the references to the original descriptions as far as possible are made. Identification of some of the freshwater species, however, was made relying only on another work by Hustedt (1930) on freshwater diatoms. Additional references are selected from the descriptions and illustrations which were particularly helpful for the present identifications. Synonyms are mentioned only in the case where they are not cited in the previous works. Remarks are included when necessary to elucidate the concept of the taxon adopted in the present study. Among those listed here, most of the marine planktonic species, which are useful for the diatom zonation, are illustrated; their plate and figure numbers are shown in brackets.

\section{Marine Planktonic Diatoms}

Actinocyclus curvatulus Jan., in Schmidt, 1878: Hustedt, 1928, Kieselalg, I, p. 538, fig. 307; Hustedt, 1958, p. 129, pl. 8, figs. $82-83$; Koizumi, 1968 , p. 207 , pl. 32 , figs. $1-2$. Remarks: The species having relatively coarse areolae, 6-7 in $10 \mu$ at the middle of the radius, covered by dense areolation, shows the "Coscinodiscus curvatulus type" regular fasciculation of areolae, with an ocellus covered with several small areolae. [Plate 1, Figures 1-6]

Actinocyclus divisus (Grun.) Hust., Hustedt, 1958: p. 129, pl. 8, fig. 81 ; Koizumi, 1968 , p. 207 , pl. 32, fig. 3. Remarks: The species is distinguished from Actinocyclus curvatulus Jan. in having the fasciculation of areolae more irregular, less curvatulation and by the presence of a "granuliert" central area enclosed by an irregularly shaped ring. [Plate 1, Figures 7-12]

Actinocyclus ingens Ratt., Rattray, 1890: p. 149, pl. 11, fig. 7; Kanaya, 1959 , p. 97 , pl. 7 , figs. $6-9$, pl. 8 , figs. $1-4$; Sheshukova-Poretzkaya, 1967 , p. 194 , pl. 29 , fig. 8, pl. 30, figs. la-e, pl. 31, figs. la-e; Koizumi, 1968, p. 207, pl. 32, figs. 5-6; Kanaya, 1971 , p. 554 , pl. 40.6 , figs. 1-8. Remarks: Two kinds of specimens were found, those with the concentric undulation of the valve surface and those with valves almost flat. Separation into two different taxa has not been successful because they show a continuous transition from one extreme to another. [Plate 1, Figures 13-14; Plate 2, Figures 1-2]

Actinocyclus ochotensis Jousé, 1968: p. 17, pl. 2, figs. 2-5; Donahue, 1970 , p. 135 , pl. 2 , figs. $2-5$. Remarks: In the valve center is often a small smooth area without areolae, but minute granular markings occupy the area in many specimens below the Thalassiosira zabelinae Zone. [Plate 2, Figures 3-7]

Actinocyclus oculatus Jousé, 1968: p. 18, pl. 2, figs. 6-7; Donahue, 1970 , p. 135, pl. 2, figs. 6-7. [Plate 2, Figures 8-9]

Asterolampra marylandica Ehr., 1845: Hustedt, 1927, Kieselalg., I, p. 485 , figs. $270-271$; Cupp, 1943 , p. 68 , figs. 31a-b; Sheshukova-Poretzkaya, 1967 , p. 189 , pl. 29, fig. 3 .

Asteromphalus arachne (Bréb.) Ralfs, in Pritchard, 1861: Hustedt, 1929, Kieselalg., I, p. 493, fig. 276.

Asteromphalus darwinii Ehr., 1844: Schmidt, 1876, Atlas, pl. 38, fig. 16; Wornardt, 1967 , p. 51 , fig. 82 ; Koizumi, 1968 , p. 209 , pl. 32, fig. 7; Hanna, 1970, p. 180, fig. 90.

Asteromphalus robustus Castr., 1875: Hustedt, 1929, Kieselalg., I, p. 496, fig. 278; Sheshukova-Poretzkaya, 1967, p. 190, pl. 29, fig. 2 .

Bacteriosira fragilis Gran, 1900: Hustedt, 1929, Kieselalg., I, p. 544, fig. 310; Jousé, 1962, pl. 2, fig. 15; Sheshukova-Poretzkaya, 1967 , p. 202, pl. 33, figs. 3a-b.

Biddulphia aurita (Lyng.) Bréb. and God., 1838: Hustedt, 1930, Kieselalg., I, p. 846, fig. 501; Cupp, 1943, p. 161, fig. 112A Sheshukova-Poretzkaya, 1967 , p. 214 , pl. 34, fig. 5; Wornardt, 1967 , p. 60 , fig. 113.

Coscinodiscus endoi Kanaya, 1959: p. 76, pl. 3, figs. 8-11; Koizumi, 1968 , p. 211, pl. 32, figs. 21-22. [Plate 2, Figure 10]

Coscinodiscus excentricus Ehr., 1839: Hustedt, 1928, Kieselalg., I, p. 388 , fig. 201 ; Cupp, 1943 , p. 52 , fig. 1 ; Kanaya, 1959 , p. 77 , pl. 3, figs. 12-13; Koizumi, 1968, p. 211, pl. 32, figs. 23-24. [Plate 2, Figures 11-12]

Coscinodiscus excentricus Ehr. var. fasciculata Hust., Hustedt, 1928: Kieselalg., I, p. 390, fig. 202. Synonyms: As Coscinodiscus denarius Schmidt, Jousé, 1962, pl. 3, fig. 4, and Thalassiosira pacifica Gran and Angst, Jousé, 1971a, pl. 31.2, fig. 10. Remarks: The individuals showing the tangentially fasciculated sculptures have their areolae finer $(6.5-7$ in $10 \mu$ in near center) 


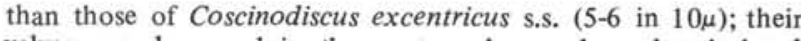
valves are depressed in the center where subangular, isolated areolae form a loose meshwork, and one or a few round pores are found; size of the valves range from 50 to $70 \mu$ in diameter. [Plate 2, Figures 13-16]

Coscinodiscus excentricus Ehr. var. jousei Kanaya (MS), in Kanaya and Koizumi, 1966: p. 125. Synonyms: As Thalassiosira excentrica (Ehr.) Cl., Jousé, 1962, pl. 3, fig. 1; Jousé, 1969, pl. 5, fig. 11; Jousé et al., 1969, pl. 9, fig. 4; Jousé, 1971a, pl. 31.1, fig. 1. Remarks: Valve circular, $30-60 \mu$ in diameter, flat or broadly depressed in center, beveled through mantle to valve edge. Areolae hexagonal, arranged in straight or slightly curved tangential rows; with secondary sculpture of shorter outwardly concave rows, border on the outside. Hexagonal areolae 5-6 in $10 \mu$ near center, $8-10$ in $10 \mu$ throughout most part of a valve. Margin relatively broad, $1.5-2.5 \mu$ in width, with strong radial striae, 13-16 in 10 $\mu$ Marginal spines lacking. A few to several small pores near center. Distinguished from the species mainly by a well-developed valve mantle which is seen as darker ring surrounding the outer border of valve, particularly under lower magnification (e.g., $40 \times 10$ ). [Plate 3, Figures 1-6]

Coscinodiscus excentricus Ehr. var. leasareolatus Kanaya (MS), in Kanaya and Koizumi, 1966, p. 125. Synonyms: As Thalassiosira pacifica Gran and Angst, Jousé, 1962, pl. 63, fig. 11; Jousé, 1969, pl. 8, figs. 9-10; Jousé, 1971a, pl. 31.2, fig. 9. Remarks: Valve almost flat, $30-60 \mu$ in diameter, depressed in center, falls off at margin. Areolae subangular, meshwork of areolae tends to be loose, particularly in the center of the valve; a pore and a few smaller subangular areolae in the center. Sculpturing as in Coscinodiscus excentricus s.s. with areolae in more or less parallel rows of tangential lines that curve, are concave outward in outer border, and bent near the center of the valve. Areolae 6-7 in $10 \mu$ near center, smaller toward outer, 7-9 in 10 $\mu$ near margin. Margin narrow, about $1 \mu$ in width; marginal striae distinct, $10-15$ in $10 \mu$; marginal spines short, set along the inner edge of margin in uniform intervals. [Plate 3, Figures 7-11]

Coscinodiscus kutzingi Schmidt, 1878: Hustedt, 1928, Kieselalg., I., p. 398 , fig. 209 ; Koizumi, 1968 , p. 211 , pl. 32 , fig. 25 ; Hanna, 1970 , p. 184 , fig. 7.

Coscinodiscus marginatus Ehr., 1843: Hustedt, Kieselalg., I, p. 416, fig. 223; Cupp, 1943, p. 55, fig. 19; Sheshukova-Poretzkaya, 1967 , p. 156 , pl. 11 , fig. 9 , pl. 17 , figs. $4 \sigma-B$, pl. 18 , figs. $1 \sigma-2$, 1e; Koizumi, 1968, p. 211, pl. 33, figs. 3a-b.

Coscinodiscus marginatus Ehr. forma fossilis Jousé, 1961: 1961c, p. 68 , pl. 3, figs. 7-8. Synonyms: As Coscinodiscus marginatus Ehr., Sheshukova-Poretzkaya, 1967 , p. 156 , pl. 17, fig. 4a, pl. 18, figs. $1 \mathrm{a}, 1 \sigma$; Wornardt, 1967 , figs. 27,28 ; Hanna, 1970, p. 184, fig. 1 . Remarks: An additional and very handsome sculpture of round to elongated pores often covers the entire exterior sheath of the areolae. [Plate 3, Figures 12-14]

Coscinodiscus obscurus Schmidt, 1878: Hustedt, 1927, Kieselalg., I, p. 418 , figs. 224a-b; Sheshukova-Poretzkaya, 1967, p. 164, pl. 23 , fig. 1 .

Coscinodiscus oculus iridis Ehr. var. borealis (Bail.) Cl., Hustedt, 1928, Kieselalg., I, p. 456, fig. 253; Wornardt, 1967, p. 28, fig. 33.

Coscinodiscus pustulatus Mann, 1907: p. 257, pl. 48, fig. 3; Hanna, 1970 , p. 185 , figs. $12,19-20,23$ (not figs. 21-22, 24); Koizumi, 1972 , p. 350 , pl. 43 , fig. 12 . Remarks: The present identification is made by comparison with the figures given by Hanna (loc. cit., figs., 12, 19-20, 23; no description given), but it leaves much to be determined since the specimens are very similar to Pyxidicula weyprechtii Grun. (Hustedt, Kieselalg., I, p. 300, fig. 138). [Plate 4, Figures 1-4]

Coscinodiscus radiatus Ehr., 1839: Hustedt, 1928, Kieselalg., I, p. 240 , fig. 225; Cupp, 1943, p. 56, fig. 20; Sheshukova-Poretzkaya, 1967 , p. 153, pl. 17, fig. 2; Hanna, 1970, p. 185, figs. 4, 8, 17.

Coscinodiscus radiatus Ehr., var., in Kanaya and Koizumi, 1966, p. 126. Remarks: The name has been applied to specimens with a few interstitial meshes on a valve which otherwise is identifiable with Coscinodiscus radiatus Ehr.

Coscinodiscus rothii (Ehr.) Grun., 1878: Hustedt, 1928, Kieselalg., I, p. 400, fig. 211.
Coscinodiscus stellaris Rop., 1858: Hustedt, 1928, Kieselalg.. I, p. 396, fig. 207; Cupp, 1943, p. 53, fig. 16; Koizumi, 1968, p. 212. pl. 33, fig. 11 .

Coscinodiscus stellaris Rop. var. symbolophora (Grun.) Joerg., 1905: Hustedt, 1927, Kieselalg., I, p. 396, figs. 208a-b. Synonyms: As Coscinodiscus symbolophorus Grun., Sheshukova-Poretzkaya, 1967 , p. 167. pl. 22, figs. 3a- $\sigma$. [Plate 4 . Figures 5-6]

Coscinodiscus tabularis Grun., 1884: Hustedt, 1928, Kieselalg., I, p. 427, fig. 230; Koizumi, 1968, p. 212, pl. 33, fig. 10.

Coscinodiscus temperi Brun, in Brun and Tempère, 1889: p. 33, pl. 8 , fig. 2 ; Kanaya, 1959 , p. 84 , pl. 4 , fig. 8 ; Koizumi, 1968, p. 212 , pl. 32, fig. 28 .

Cosmiodiscus insignis Jousé, 1961: 1961c, p. 67, pl. 2, fig. 8; Sheshukova-Poretzkaya, 1967 , p. 175 , pl. 25 , figs. 2a-B; Hanna, 1970 , p. 186, figs. 9-11, 30, 32. Remarks: Valve strongly convex, $35-40 \mu$ in diameter. Areolae round to subangular, arranged in concentric and indistinct short radial rows not grouped in beams. The large rounded central area, usually hyaline, is surrounded by

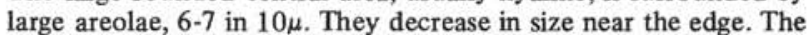
marginal zone sculptured in small areolae, $16-20$ in $10 \mu$, in radial to obliquely intersecting rows. The margin is heavy and hyaline, just inside it there is a series of slightly elongate spines or low ridges. [Plate 4, Figures 7-11]

Cosmiodiscus intersectus (Brun) Jousé, 1961: 1961c, p. 68, pl. 2, figs. 9-10; Sheshukova-Poretzkaya, 1967 , p. 174 , pl. 25 , figs. 1a- $\sigma$. Remarks: Valve slightly convex, $35-75 \mu$ in diameter. Areolae rounded, in rows grouped in beams; in each beam, the rows of areolae are parallel to the middle one. Central area usually large, rounded; the fine dots randomly distributed. [Plate 4, Figures 12-13]

Denticula hustedtii Simonsen and Kanaya, 1961: p. 501, pl. 1, figs. 19-25; Sheshukova-Poretzkaya, 1967, p. 301, pl. 47, fig. 10, pl. 48 , figs. $5 \mathrm{a}-\Gamma$; Kanaya, 1971 , p. 555 , pl. 40.5 , figs. 13-14. Remarks: The species resembles Denticula seminae Simonsen and Kanaya, but differs from it in not having shorter marginal ribs and the branching of the pseudosepta. [Plate 5, Figures 18-23]

Denticula kamtschatica Zabelina, 1934: Simonsen and Kanaya, 1961, p. 503, pl. 1, figs. 14-18; Sheshukova-Poretzkaya, 1967, p. 300 pl. 47 , figs. $9 \mathrm{a}-\sigma$, pl. 48 , figs. $4 \mathrm{a}-\delta$; Koizumi, 1968 , p. 213 , pl. 34 , figs. $7-10$; Koizumi, 1972 , p. 350 , pl. 42 , figs. 12-13. Remarks: The shorter, marginal ribs and the branching of the pseudosepta are situated near the valve edge. Secondary pseudosepta usually not observed, if present, only slightly before the ends. [Plate 5, Figures 14-17]

Denticula lauta Bail., 1854: Simonsen and Kanaya, 1961, p. 500, pl. 1, figs. 1-10; Sheshukova-Poretzkaya, 1967, p. 299, pl. 47, figs. $8 \mathrm{a}-\sigma$, pl. 48 , figs. $3 \mathrm{a}-\delta$; Koizumi, 1968 , p. 213 , pl. 34 , figs. 11a-12b; Kanaya, 1971 , p. 555 , pl. 40.5 , fig. 11. [Plate 5, Figures 24-28]

Denticula seminae Simonsen and Kanaya, 1961: p. 503, pl. 1, figs. 26-30; Sheshukova-Poretzkaya, 1967, p. 301, pl. 47, figs. 11a-B, pl. 48 , figs. $6 a-\delta$; Koizumi, 1972 , p. 350 , pl. 42 , figs. $5 \mathrm{a}-6$. Remarks: The shorter marginal ribs and the branching of the pseudosepta present at the raphe marginal side of the valve. The transitional form, which is characterized by the reduction of the secondary pseudosepta between the pseudosepta and by the noncurved polar pseudosepta, to Denticula kamtschatica Zabelina is observed more commonly in the interval from the lowest part of the Actinocyclus oculatus Zone to Denticula seminae-Denticula kamtschatica Zone. [Plate 5, Figures 1-13]

Eucampia balaustium Castr., 1886: Hustedt, 1958, p. _36, pl. 5, figs. $40-43$; Sheshukova-Poretzkaya, 1967 , p. 209 , pl. 34 , figs. $2 \mathrm{a}-\delta$.

Fragilariopsis cylindrus (Grun.) Helmck and Krieger, 1954: Hustedt, 1958 , p. 162 , figs. $145-146$; Hasle, 1965 , p. 34 , pl. 12 , figs. $6-12$, pl. 14 , figs. $1-10$, pl. 17 , figs. $2-4$; Koizumi, 1972, p. 350 , pl. 42, figs. 8-9. Remarks: The straight, parallel margins of the valve, the broadly rounded apices, the straight transapical costae confined to the rectangular part, and the more weakly silicified oblique or longitudinal costae in the semicircular part of the valve characterize the species as stated by Hasle. Recently, Hasle (1972) 
transferred this species to Nitzschia cylindrus (Grun.) as new combination. [Plate 7, Figures 1-2]

Goniothecium tenue Brun, 1894: p. 77 , pl. 5, figs. 5-6; Sheshukova-Poretzkaya, 1967, p. 232 , pl. 39 , figs. $6 a-\sigma$, pl. 40 , figs. 5a- $\sigma$. Remarks: Valves joined in pairs by short $\operatorname{cogs}, 25-55 \mu$ long, $5-8 \mu$ wide, narrow lanceolate, differing in form and sculpture; one side is convex, with indistinct parallel transverse striae, 16-24 in $10 \mu$, on the outer surrounding margin; the other side is straight or slightly concave, with short cogs of obtuse-angled end, 4-8 in 10 $\mu$. [Plate 7, Figures 7-9]

Hemidiscus cuneiformis Wall., 1860: Hustedt, 1930, Kieselalg., I, p. 904 , fig. 542; Hanna and Brigger, 1966 , p. 300 , fig. 33 ; Wornardt, 1967 , p. 36 , fig. 51 ; Koizumi, 1968 , p. 215 , pl. 34 , figs. 17-18; Hanna, 1970, p. 189, fig. 35 .

Kisseleviella carina Sheshuk., Sheshukova-Poretzkaya, 1962: p. 207, figs. 2a- $\delta$, 1a- $\sigma$; Sheshukova-Poretzkaya, 1967, p. 236, pl. 40, figs. $6 \mathrm{a}-\mathrm{B}$, pl. 41 , figs. 5a-B. Remarks: Valve lanceolate to elliptical in naviculoid shape, $19-30 \mu$ long, 6-8 $\mu$ wide, with attenuated capitate ends. A bulge, with several annular tubercles, in the center of the valve and sometimes two small bulges, with 1-2 tubercles, in addition to the central one. [Plate 7, Figures 3-4]

Mediaria splendida Sheshuk., Sheshukova-Poretzkaya, 1962: p. 210 , figs. 2, 5; Sheshukova-Poretzkaya, 1967, p. 306, pl. 47, fig. 14, pl. 48 , fig. 8 . Remarks: Represented only by broken specimens. [Plate 7, Figures 5-6]

Nitzschia fossilis (Fuengelli) Kanaya (MS), in Kanaya and Koizumi, 1970: p. 59; Koizumi, 1972 , p. 352 , pl. 42 , figs. $14 \mathrm{a}-15 \mathrm{c}$. Synonyms: As Fragilariopsis pliocena (Brun) Sheshuk., Kanaya, 1971, p. 556, pl. 40.3, figs. 7-8. Remarks: The species shows resemblance with Pseudoeunotia doliolus (Wall.) Grun. (Hustedt, 1932, Kieselalg., II, p. 258, fig. 737; Kolbe, 1954 , p. 43, pl. 3 , fig. 41), from which it differs by the transapical axis isopole.

Nitzschia reinholdii Kanaya (MS), in Kanaya and Koizumi, 1970: p. 58; Koizumi, 1972 , p. 351 , pl. 42, figs. 16a-c. Synonyms: As Fragilariopsis pliocena (Brun) Sheshuk., Sheshukova-Poretzkaya, 1967 , p. 305 , pl. 48 , fig. 7 ; Koizumi, 1968 , p. 214 , pl. 34 , figs. 13-15; Nitzschia pliocena (Brun) Worn., Wornardt, 1967, p. 88 , figs. 212-213; Fragilaria pliocena Brun, Reinhold, 1937, p. 104, pl. 12, fig. 18. Remarks: The species is related to Nitzschia marina Grun., from which it differs in the outline of the valve, lanceolate having shorter in length and wider in width, and the finer transapical costae, $11-13$ in $10 \mu$.

Porosira glacialis (Grun.) Joerg., 1905: Hustedt, 1928, Kieselalg., I, p. 315 , fig. 153 ; Jousé, 1962 , pl. 2, fig. 1 , pl. 79 , fig. 11. Remarks: The present identification has been made relying mainly upon the illustrations given by Jousé (1957, pl. 3, figs. $4 \mathrm{a}-\mathrm{b})$, who showed the valves of the vegetative cell and the resting-spore of the species. On the valve of the vegetative cell, the fasciculation is not clear and the somewhat sinuous nature of the radial rows is more pronounced; areolae coarser, about 14 in $10 \mu$ at the middle part, dwindle to the margin, and are dense with spines in the outer border. The valve of the resting-spore are broadly convex, $30-40 \mu$ in diameter; areolae, $15-16$ in $10 \mu$, arranged in narrow radial fasciculae; shortened radial rows fill the interstices between fasciculae in the outer border; many short spines present. [Plate 4, Figures 15-18]

Pseudopodosira elegans Sheshuk., Sheshukova-Poretzkaya, 1964: p. 75, pl. 2, figs. 4-5; Sheshukova-Poretzkaya, 1967, p. 178, pl. 24, fig. 3 , pl. 25 , fig. 4 ; Koizumi, 1972 , p. 352 , pl. 43 , figs. $3-4$. [Plate 4, Figure 14]

Rhizosolenia curvirostris Jousé, 1968: p. 19, pl. 3, figs. 1-3; Jousé, 1968 , pl. 9, figs. 5-6, 10; Jousé, 1971a, pl. 31.3, figs. 7-8; Donahue, 1970 , p. 135, pl. 1, fig. a. [Plate 5, Figures 29-31]

Rhizosolenia curvirostris Jousé var. inermis Jousé, 1971: 1971b, p. 15, pl. 2, figs. 1-3; Donahue, 1970, p. 136, pl. 1, figs. b-c. [Plate 5, Figures 32-331

Rhizosolenia hebetata (Bail.) Gran forma hiemalis Gran, 1904: Hustedt, 1929, Kieselalg., I, p. 590, fig. 337; Jousé, 1957, pl. 4, fig. 3; Hendey, 1964, p. 150, pl. 3, fig. 6. [Plate 5, Figures $34-35]$
Rhizosolenia styliformis Brig., 1858: Hustedt, 1929, Kieselalg., I, p. 584 , fig. 333; Hendey, 1964 , p. 150 , pl. 2 , fig. 1.

Rhizosolenia sp.a, in Koizumi, 1968: p. 217, pl. 34, figs. 22a-b. Remarks: The form shows close resemblance to Rhizosolenia hebetata (Bail.) Gran forma hiemalis Gran, but apical process thick, solid, hollow and round spine, occasionally twisted. This form also resembles Rhizosolenia sp. 1 given by SheshukovaPoretzkaya (1967, p. 204, pl. 33, figs. 5a- $\sigma$ ). [Plate 5, Figure 36]

Rhizosolenia sp. c, in Koizumi, 1968: p. 217, pl. 34, fig. 24. Remarks: The form having a long cavity penetrating the tip of the process. [Plate 5, Figures 37-38]

Rhizosolenia sp.e, in Koizumi, 1968: p. 217, pl. 34, fig. 26. Remarks: Apical process somewhat bent, with a cavity gradually opening to the tip of the process. [Plate 5, Figure 39]

Rhizosolenia sp.2, in Sheshukova-Poretzkaya, 1967: p. 204, pl. 33, fig. 6. Remarks: Valve fringed by a hyaline strip, markedly tapering off at the valve apex and continuing over the outgrowth. Valve sculptured in dots in longitudinal to obliquely intersecting rows. [Plate 5, Figures 40-41]

Rouxia peragalli Brun and Herib., in Heribaud, 1893: Hanna, 1930, p. 180 , pl. 14 , figs. 1,5 ; Sheshukova-Poretzkaya, 1967 , p. 294 , pl. 43 , fig. 17; Koizumi, 1968 , p. 217 , pl. 35 , figs. 1-2. Remarks: Valves are shorter, usually about $30 \mu$ long and $7-8 \mu$ in width, narrowly elliptical to elliptical-lanceolate with rounded ends, at times slightly attenuated. [Plate 7, Figure 10]

Rouxia peragalli Brun and Herib., forma californica (Perag.) Sheshuk., Sheshukova-Poretzkaya, 1956: p. 73, figs. 9-16; Sheshukova-Poretzkaya, 1967 , p. 295 , pl. 43, fig. 19, pl. 47, figs. 5a- $\sigma$. Remarks: Valve narrowly linear, straight, with strongly attenuated ends. [Plate 7, Figure 11]

Stephanopyxis horridus Koizumi, 1972: 1972, p. 348, pl. 42, figs. 1a-2b. Remarks: The species resembles Stephanopyxis schencki Kanaya, but differs from it in not having petal-shaped areolae on the brim and hyaline margin. [Plate 6, Figures 1-4]

Stephanopyxis inermis Jousé, 1961: 1961c, p. 60, pl. 1, fig. 2, pl. 3, figs. 1-2; Sheshukova-Poretzkaya, 1967, p. 135, pl. 11, figs. 5a- $\sigma$, pl. 12, fig. 8. Synonyms: As Stephanopyxis appendiculata Ehr., Hanna, 1970 , p. 193 , fig. 58. Remarks: Areolae are convex, 3-5 in $10 \mu$, distributed in more or less straight rows, perpendicular to inclined to the central axis of the valve. Spines missing. [Plate 6, Figures 5-10]

Stephanopyxis schenckii Kanaya, 1959: p. 67, pl. 2, figs. 2-4; Sheshukova-Poretzkaya, 1967 , p. 136, pl. 3, fig. 2, pl. 13, figs 2B- $\delta$; Koizumi, 1968, p. 218 , pl. 35 , figs. 5a-6b. [Plate 6 , Figures 11-12]

Stephanopyxis turris (Grev. and Arn.) Ralfs, in Pritchard, 1861: Hustedt, 1928, Kieselalg., I, p. 304, fig. 140; Cupp, 1943, p. 40, fig. 9; Kanaya, 1959 , p. 69 , pl. 2, figs. 5-7. Synonyms: As Stephanopyxis appendiculata Ehr., Hanna, 1970, p. 193, figs. 99-100. Remarks: Areolae are flat hexagonal, $2-6$ in $10 \mu$, in tangential rows intersecting in three directions. Spines are present in the middle of the valve. Although they were not counted separately, var. cylindrus Grun. (Hustedt, 1928, Kieselalg., I, p. 305 , fig. 141) are present together with typical specimens. [Plate 6, Figures 13-16]

Synedra kamtschatica Grun., 1862: Hustedt, 1932, Kieselalg., II, p. 214, figs. 708a-b; Sheshukova-Poretzkaya, 1967, p. 245.

Synedra jouseana Sheshuk., Sheshukova-Poretzkaya, 1962: p. 208, fig. 4; Sheshukova-Poretzkaya, 1967 , p. 245 , pl. 42, figs. 4a- $\sigma$, figs. 43 , figs. $12 \mathrm{a}-\sigma$; Kanaya, 1971 , p. 556 , pl. 40.5 , fig. 15. Remarks: Valve narrow-lanceolate, gradually tapering off toward the narrow ends, at times attenuated and very slightly capitate. [Plate 6, Figure 17]

Thalassionema nitzschioides Grun., 1881: Hustedt, 1932, Kieselalg., II, p. 244 , fig. 723 ; Cupp, 1943, p. 182, fig. 133; Hanna, 1970, p. 194 , fig. 37.

Thalassionema nitzschioides Grun. vars. Remarks: Following three varieties are presented; Thalassionema nitzschioides Grun. v. inflata Heiden and Kolbe, 1928: p. 564, pl. 35, fig. 116 , Thalassionema nitzschioides Grun. v. parva Heiden and Kolbe, 1928: p. 564, pl. 35, fig. 118, Thalassionema nitzschioides Grun. v. incurvata Heiden and Kolbe, 1928: p. 564, pl. 35, fig. 117. 
Thalassiosira antiqua (Grun.) Cl., Cleve-Euler, 1941: p. 173, figs. 4-5, 74-84; Cleve-Euler, 1951, p. 72, fig. 119a; SheshukovaPoretzkaya, 1967, p. 143, pl. 14, figs. 3a, 6; Koizumi, 1968, p. 218, pl 35, fig. 11. Synonyms: As Coscinodiscus pustulatus Mann, Hanna, 1970 , p. 185 , fig. 24 . Remarks: In the central area of the valve a group of mucous pores is surrounded by several larger areolae at times forming a rosette. Margin well defined, with coarse radial striae. [Plate 7, Figure 12]

Thalassiosira convexa Much., Muchina, 1965: p. 22, pl. 11, figs. 1-2; Koizumi, 1972, p. 353, pl. 43, figs. 15a-16b. Synonyms: As Coscinodiscus muckhina (Much.) Donahue, 1970: p. 136, pl. 3, figs. a-f. [Plate 7, Figures 13-15]

Thalassiosira decipiens (Grun.) Joerg., 1905: Hustedt, 1928, Kieselalg., I, p. 322, fig. 158; Cupp, 1943, p. 48, fig. 10; Sheshukova-Poretzkaya, 1964 , p. 74 , pl. 1, fig. 2. Remarks: The areolae grow somewhat smaller away from the center of the valve, at times with porous exterior walls. [Plate 7, Figures 16-18]

Thalassiosira gravida Cl., 1896: Hustedt, 1928, Kieselalg., I, p. 325, fig. 161; Cupp, 1943, p. 48, fig. 11; Hasle, 1968, p. 196, figs. $3-4$; Koizumi, 1972, p. 353, pl. 43, figs. 11a-b. [Plate 7, Figures 19-21]

Thalassiosira gravida Cl, forma fossilis Jousé, 1961: p. 63, pl. 1, fig. 9; Sheshukova-Poretzkaya, 1967 , p. 147 , pl. 15 , figs. 1a-B; Koizumi, 1972, p. 353, pl. 43, fig. 10. [Plate 7, Figures 22-24]

Thalassiosira hyalina (Grun.) Grun., 1897: Hustedt, 1928, Kieselalg., I, p. 323, fig. 159; Jousé, 1962, pl. 2, fig. 4, Jousé et al., 1969, pl. 4, fig. 1; Koizumi, 1972, p. 353 , pl. 43, fig. 7. Remarks: The identification has been made relying mainly upon the illustration given by Jousé (l. c.). Aerolae very small, 18-20 in $10 \mu$, in radial rows. A small central area with several isolated areolae. The marginal zone shows numerous fine spines and a single large spine. [Plate 8, Figures 1-2]

Thalassiosira kryophila (Grun.) Joerg., 1905: Hustedt, 1928, Kieselalg., I, p. 324, fig. 160; Jousé, 1957, pl. 3, fig. 6; Jousé, 1962, pl. 2, fig. 5; Sheshukova-Poretzkaya, 1967, p. 146, pl. 14, fig. 6; Koizumi, 1968, p. 218, pl. 35, figs. 14-15; Koizumi, 1972, p. 354, pl. 43 , fig. 9 . Remarks: Areolae in radial rows forming beams, $14-16$ in $10 \mu$ in the middle. A row of numerous, evenly spaced spines, 6-7 in $10 \mu$ with a single large spine. [Plate 8, Figure 31

Thalassiosira lineata Jousé, 1968: p. 13, pl. 1, figs. 1-2. Remarks: Valve flat, $20-35 \mu$ in diameter, with a narrow, finely striated margin. Valve surface uniformly areolate. The rows of areolae in straight lines are arranged on three regular tangential systems. The smaller the valve, the finer the areolae. [Plate 7, Figures 28-29]

Thalassiosira manifesta Sheshuk., Sheshukova-Poretzkaya, 1964: p. 72, pl. 1, figs. 6-7; Sheshukova-Poretzkaya, 1967, p. 147, pl. 14, figs. 9a-b; Koizumi, 1968, p. 219, pl. 35, figs. 16-17.

Thalassiosira nidulus (Tem. and Brun) Jouse, 1961: 1961c, p. 63, pl. 3, figs. 4-5; Sheshukova-Poretzkaya, 1967, p. 140, pl. 11, figs, $8 \mathrm{a}-\sigma$, pl. 14 , figs. $1 \mathrm{a}-\sigma$; Koizumi, 1968, p. 219 , pl. 35 , figs. $21-22$; Koizumi, 1972,p. 354, pl. 43, fig. 6. [Plate 7, Figures 25-26]

Thalassiosira nordenskioldi Cl., 1875: Hustedt, 1928, Kieselalg., I, p. 321 , fig. 157; Jousé, 1962 , pl. 2, fig. 6 , pl. 62, fig. 2, pl. 79, figs. $3-5$; Hasle, 1968 , p. 196 , figs. 2, 4, 8; Koizumi, 1972, p. 354 , pl. 43 , fig. 8 . Remarks: A mucous thread at the center of the valve and the distinct submarginal circlet of fairly large spines were observed on the specimens. [Plate 8, Figure 4]

Thalassiosira oestrupi (Ostf.) Pr.-Lavr., 1956: Hasle, 1960, p. 8, pl. 1 , figs. 5-7; Jousé, 1968 , p. 13, pl. 1, figs. 3-7; Koizumi, 1968, p. 219, pl. 35, figs. 24-25. Remarks: Two large, isolated pores, some distance apart, are recognized in the central area of the valve. [Plate 7, Figure 27]

Thalassiosira punctata Jousé, 1961: 1961c, p. 64, pl. 1, figs. 7-9; Sheshukova-Poretzkaya, 1967, p. 151, pl. 14, fig. 10, pl. 17, figs. 1a-b; Hanna, 1970, p. 194, figs. 5-6. Remarks: Areolae rounded, inconsistent in form and size, closely and randomly distributed, about 12 in $10 \mu$, with tubercles? evenly distributed among them in the peripheral part of the valve. [Plate 8, Figures 7-9]

Thalassiosira undulosa (Mann) Sheshu., Sheshukova-Poretzkaya, 1967: p. 148, pl. 16, figs. 1a-B. Synonyms: As Coscinodiscus undulosa Mann, Hanna, 1970, p. 186, fig. 3. [Plate 8, Figures $5-6]$

Thalassiosira usatschevii Jousé, 1961: 1961c, p. 64, pl. 3, fig. 6; Sheshukova-Poretzkaya, 1967 , p. 150 , pl. 15 , figs. $3 a-\delta$. Remarks: Differs from Thalassiosira zabelinae Jouse by the larger size and flatter areolae, and by their uniform size over the entire valve. [Plate 8, Figures 13-15]

Thalassiosira zabelinae Jouse, 1961: 1961c, p. 66, pl. 2, figs. 1-7; Sheshukova-Poretzkaya, 1967, p. 149, pl. 16, figs. 2a-Г; Koizumi, 1968 , p. 219 , pl. 35 , figs. 27 a-28b; Koizumi, 1972 , p. 354 , pl. 43, figs. 17a-b. Remarks: Specimens which are very similar to Pyxidicula weyprechtii Grun. (Hustedt, 1927, Kieselalg., I., p. 300 , Fig. 138) were observed in the present samples, but separation of two different taxa was not possible. [Plate 8, Figures 10-12].

Thalassiothrix longissima Cl. and Grun., 1880: Hustedt, 1932, Kieselalg., II, p. 247, fig. 726; Cupp, 1943, p. 184, fig. 134; Jousé, 1962 , pl. 3 , fig. 12 , pl. 62, fig. 13; SheshukovaPoretzkaya, 1967, p. 250, pl. 42, fig. 11. [Plate 8, Figure 16]

\section{Marine Tychopelagic and Benthonic Diatoms}

Actinoptychus splendens (Shadb.) Ralfs, in Pritchard, 1861: Hustedt, 1929, Kieselalg., I, p. 478, fig. 265; Kanaya, 1959, pl. 6, fig. 6 ; Hendey, 1964 , p. 95 , pl. 22, fig. 1; Hanna, 1970, p. 179 , figs. 25-26, 28, 4, 44 .

Actinoptychus undulatus (Bail.) Ralfs, in Pritchard, 1861: Hustedt, 1929, Kieselalg., I, p. 475 , fig. 264 ; Cupp, 1943, p. 67, fig. 29 , pl. 5, fig. 1; Sheshukova-Poretzkaya, 1967, p. 184, pl. 27 figs. la $-\delta$, pl. 28 , figs. 1a-b. Synonyms: As Actinoptychus senarius (Ehr.) Ehr., Hanna, 1970, p. 179, figs. 38-39, 45, 76.

Amphora costata W. Sm., 1853: Cleve-Euler, 1953, p. 99, fig. 690 ; Sheshukova-Poretzkaya, 1967, p. 297, pl. 47, fig. 6, pl. 48, fig. 1.

Bacillaria paradoxa Gmelin, 1788: Hustedt, 1930, Bacill., p. 396, fig. 755. Synonyms: As Bacillaria paxillifer (Müller) Hendey, 1964 , p. 274 , pl. 21 , fig. 5 .

Cladogramma californicum Ehr., 1854: Van Heurck, 1881, pl. 83, figs. 8-9; Kanaya, 1959, p. 87, pl. 6, fig. 1; Wornardt, 1967, p. 42 , fig. 64 ; Koizumi, 1968 , p. 210 , pl. 32 , fig. 19.

Cocconeis antiqua Temp. and Brun, in Brun and Tempere, 1889: p. 32 , pl. 8 , fig. 5 ; Kanaya, 1959 , p. 107 , pl. 10 , figs. $1-2$; Sheshukova-Poretzkaya, 1967 , p. 269 , pl. 45, fig. 1; Hanna, 1970 p. 183 , fig. 48.

Cocconeis californica Grun., 1881: Hustedt, 1933, Kieselalg., II, p. 343 , fig. 796; Sheshukova-Poretzkaya, 1967, p. 269, pl. 45, fig. 1.

Cocconeis californica Grun. var. kerguelensis Heiden and Kolbe, 1928: p. 585, pl. 5, fig. 109; Sheshukova-Poretzkaya, 1967, p. 268 pl. 43, fig. 10 .

Cocconeis costata Greg., 1855: Hustedt, 1933, Kieselalg., II, p. 332, fig. 785 ; Miller, 1964 , p. 48 , pl. 5, fig. 2; Sheshukova-Poretzkaya, 1967 , p. 262 , pl. 44 , figs. $4 a-B$.

Cocconeis curvirotunda Temp. and Brun, in Brun and Tempère, p. 32, pl. 8, fig. 6; Schmidt, 1896, Atlas, pl. 195, figs. 12-16; Kanaya, 1959, p. 108, pl. 10, fig. 3.

Cocconeis dirupta Greg., 1857: Hustedt, 1933, Kieselalg., II, p. 354, fig. 809 .

Cocconeis disculus (Schum.) Cl., 1895: Hustedt, 1933, Kieselalg., II, p. 345 , fig. 799 ; Hendey, 1964 , p. 178 , pl. 28 , fig. 19; Patrick and Reimer, 1966 , p. 239 , pl. 15, figs. 1-2.

Cocconeis pribilofensis Hanna, 1970: p. 184, fig. 34.

Cocconeis scutellum Ehr., 1938: Hustedt, 1933, Kieselalg., II, p. 337, fig. 790; Miller, 1964, p. 48, pl. 5, figs. 4-5; Hendey, 1964, p. 180 , pl. 27 , fig. 8 ; Sheshukova-Poretzkaya, 1967, p. 264, pl. 44 , fig. 7.

Cocconeis vitrea Brun, 1891: p. 19, pl. 18, fig. 2; Kanaya, 1959, p. 110 , pl. 10, fig. 6 ; Sheshukova-Poretzkaya, 1967 , p. 271 , pl. 45 , figs. 3a-b (not fig. 3B); Wornardt, 1967, p. 81, figs. 183-184.

Coscinodiscus lacustris Grun., 1880: Hustedt, 1928, Kieselalg., I, p. 432 , fig. 235 ; Ichikawa, 1960 , p. 192 , pl. 4, fig. 29 , Sheshukova-Poretzkaya, 1967, p. 165, pl. 22, fig. 2.

Cymatosira belgica Grun., 1880: Hustedt, 1931, Kieselalg., II, p. 127, fig. 649; Hendey, 1964, p. 160. 
Cymatosira debyi Temp. and Brun, in Brun and Tempère, 1889: $\mathrm{p}$. 36, pl. 7, figs. 18a-b; Sheshukova-Poretzkaya, 1967, p. 237, pl. 40 , fig. 7 , pl. 41 , fig. 6 .

Diploneis interrupta (Kütz.) Cl., 1894: Hustedt, 1937, Kieselalg., II, p. 602 , fig. 1019a; Patrick and Reimer, 1966, p. 416, pl. 36, fig. 12; Sheshukova-Poretzkaya, 1967, p. 277 , pl. 46, fig. 1 .

Diploneis smithi (Breb.) Cl., 1894: Hustedt, 1937, Kieselalg., II, p. 647, fig. 1051; Lohman, 1938, p. 84, pl. 23, fig. 10; Hendey, 1964 , p. 225 , pl. 32 , fig. 10 ; Patrick and Reimer, 1966, pl. 410, pl. 38 , fig. 2.

Diploneis subcincta (A.S.) Cl., 1894: Hustedt, 1937, Kieselalg., II, p. 680 , fig. 1072 ; Ichikawa, 1960 , p. 210 , pl. 7, fig. 76 ; Sheshukova-Poretzkaya, 1967 , p. 280 , pl. 46, fig. 4.

Grammatophora arcuata Ehr., 1854: Hustedt, 1931, Kieselalg., II, p. 42, fig. 567; Miller, 1964, p. 46, pl. 3, figs. 13-15; Sheshukova-Poretzkaya, 1967 , p. 253 , pl. 42 , figs. 9a-B.

Lithodesmium undulatum Ehr., 1840: Hustedt, 1930, Kieselalg., I, p. 789 , fig. 461 ; Cupp, 1943 , p. 150 , fig. 108; Cleve-Euler, 1951, p. 112, fig. 238; Hendey, 1964, p. 111, pl. 6, fig. 6; Hanna, 1970, p. 190 , fig. 91 .

Melosira clavigera Grun., in Schmidt, Atlas, 1876: pl. 175, figs. 21-24, pl. 202, figs. 8-9; Hanna, 1970, p. 190, figs. 52, 54 .

Melosira sulcata (Ehr.) Kütz., 1844: Hustedt, 1928, Kieselalg., I, p. 276, fig. 119; Cupp, 1946, p. 40, fig. 2 ; Kanaya, 1959, p. 64, pl. 1, figs. 4-7; Miller, 1964, p. 44, pl. 1, figs. 10-16; Mertz, 1966, p. 14, pl. 1, fig. 2; Sheshukova-Poretzkaya, 1967 , p. 126 , pl. 10, fig. 5, pl. 11, figs. 4a-b; Hanna, 1970, p. 190, figs. 50-51, 53.

Navicula directa (W. Sm.) Ralfs, in Pritchard, 1861: Schmidt, 1874, Atlas, pl. 47, figs. 1-3.

Navicula distans (W. Sm.) Schmidt, 1874: Atlas, pl: 46, figs. 11-14; Hendey, 1964, p. 203, pl. 27, fig. 13; Sheshukova-Poretzkaya, 1967 , p. 282 , pl. 46 , fig. 7.

Nitzschia panduriformis Greg., 1857: Schmidt, 1921, Atlas, pl. 331, figs. 19-21; Hendey, 1964, p. 279.

Rabdonema arcuatum (Lyngb.) Kütz., 1844: Hustedt, 1931, Kieselalg., II, p. 20, figs. 549a-B, 549f-g; Hendey, 1964, p. 172, pl. 35 , figs. 10-12.

Rabdonema japonicum Tem. and Brun in Brun and Tempere, 1889: p. 53, pl. 1, fig. 6; Schmidt, 1899, Atlas, pl. 218, figs. 18-21, pl. 219, figs. 7-9; Sheshukova-Poretzkaya, 1967, p. 258, pl. 43, fig. 14 , pl. 44 , figs. $1 \mathrm{a}-\delta$; Hanna, 1970 , p. 192 , figs. $47,92-93,95$.

Raphidodiscus marylandicus Chris., 1887: Hanna, 1932, p. 208, pl. 14, figs. 3-4; Lohman, 1948, p. 186, pl. 11, fig. 13.

Rhaphoneis amphiceros Ehr., 1844: Hustedt, 1931, Kieselalg., II, p. 174 , fig. 680; Ichikawa, 1960 , p. 204 , pl. 6, fig. 60; Hendey, 1964 , p. 154 , pl. 26 , figs. $1-4$; Hanna, 1970 , p. 192 , figs. 29 , 55-56.

Rhaphoneis angustata Pant., 1886: I, p. 33, pl. 11, fig. 97, pl. 30, fig. 313 ; Lohman, 1948 , p. 180 , pl. 11, fig. 11; SheshukovaPoretzkaya, 1967, p. 241, pl. 41, figs. 8a-b, pl. 43, fig. 2.

Rhaphoneis sachalinensis Sheshuk., Sheshukova-Poretzkaya, 1967: p. 242 , pl. 42 , fig. 2 .

Rhaphoneis surirella (Ehr.) Grun., 1880: Hustedt, 1931, Kieselalg., II, p. 173 , figs. $679 \mathrm{a}-\mathrm{c}$; Lohman, 1941, p. 82 , pl. 17, fig. 6 ; Hendey, 1964 , p. 155 , pl. 26, figs. 11-13.

Stictodiscus hardmanianus Grev., Greville, 1865: p. 98, pl. 8, fig. 4; Schmidt, 1888, Atlas, pl. 131, fig. 5; Hanna, 1970, p. 121, pl. 21, figs. 1-2; Sheshukova-Poretzkaya, 1967, p. 182, pl. 26, fig. 9.

Trachyneis aspera (Ehr.) Cl., 1894: Hendey, 1964, p. 236, pl. 29, fig. 13.

\section{Fresh-Water Diatoms:}

Achnanthes lanceolata (Bréb.) Grun., 1880: Hustedt, 1933, Kieselalg., II, p. 408, fig. 863; Patrick and Reimer, 1966, p. 269 , pl. 18 , figs. $1-10$.

Cocconeis placentula Ehr., 1838: Hustedt, 1933, Kieselalg., II, p. 347 , figs. 802a-b; Patrick and Reimer, 1966, p. 240, pl. 15, fig. 7; Van Landingham, 1967 , p. 31, pl. 4, figs. 26, 29-31.

Cymbella lacustris (Ag.) Cl., 1894: Hustedt, 1933, Bacill., p. 357, fig. 658 .
Cymbella ventricosa Kütz., 1844: Hustedt, 1930, Bacill., p. 359, fig. 661; Hanna, 1932, p. 379, pl. 32, fig. 3; Van Landingham, 1964, p. 47 , pl. 23, figs. 1-39; Van Landingham, 1967, p. 43, pl. 11, fig. $7-11$.

Diatoma anceps (Ehr.) Kirch., 1878: Hustedt, 1930, Bacill., p. 130, fig. 117; Hustedt, 1931, Kieselalg., II, p. 104, fig. 632; Van Landingham, 1964, p. 23, pl. 24, figs. 1-3.

Epithemia argus Kütz., 1844: Hustedt, 1930, Bacill., p. 383, fig. 727 a.

Epithemia zebra (Ehr.) Kütz., 1844: Hustedt, 1930, Bacill., p. 384, fig. 729.

Eunotia praerupta Ehr., 1843: Hustedt, 1930, Bacill., p. 174, fig. 211; Hustedt, 1932, Kieselalg., II, p. 280, figs. 747a-e.

Fragilaria brevistriata Grun., 1881: Hustedt, 1931, Kieselalg., II, p. 168 , figs. 696a-e; Akutsu, 1964, p. 273, pl. 61, fig. 10; Patrick and Reimer, 1966, p. 128, pl. 4, fig. 14; Van Landingham, 1967, p. 21 , pl. 12 , figs. 5-10.

Fragilaria construens (Ehr.) Grun., 1862: Hustedt, 1931, Kieselalg., II, p. 156 , figs. $670 \mathrm{a}-\mathrm{c}$; Akutsu, 1964 , p. 274 , pl. 61 , fig. 11 ; Patrick and Reimer, 1966, p. 125, pl. 4, fig. 4; Van Landingham, 1967 , p. 23, pl. 12 , figs. 1,11 .

Fragillaria harrissonii W. Sm., 1856: Hustedt, 1930, Bacill., p. 139, fig. 132.

Gomphonema angustatum (Kütz.) Rabh., 1864: Hustedt, 1933, Bacill., p. 373, fig. 690.

Navicula rhynchocephela Kütz., 1844: Hustedt, 1933, Bacill., p. 296, fig. 501.

Pinnularia gibba Ehr., 1871: Hustedt, 1930, Bacill., p. 327, fig. 600; Akutsu, 1964 , p. 278 , pl. 65 , fig. 1.

Pinnularia globiceps Greg., 1856: Hustedt, 1930, Bacill., p. 319, fig. 579.

Pinnularia lata (Bréb.) W. Sm., 1853: Hustedt, 1930, Bacill., p. 324, fig. 595; Patrick and Reimer, 1966, p. 619, pl. 59, figs. 1-2; Hanna, 1970, p. 191, fig. 33.

Pinnularia quadratarea Schmidt, 1905: Atlas, pl. 260, figs. 31, 33-35; Cleve-Euler, 1955, IV, p. 10, fig. 982b; SheshukovaPoretzkaya, 1967 , p. 289 , pl. 47, fig. 1.

Pinnularia ruttneri Hust., in Schmidt, 1934: Atlas, pl. 390, figs. 6-7; Patrick and Reimer, 1966, p. 638, pl. 64, fig. 3, Hanna, 1970, p. 191, fig. 101.

Rhoicosphenia curvata (Kütz.) Grun., 1867: Hustedt, 1933, Kieselalg., II, p. 430, fig. 879; Patrick and Reimer, 1966, p. 282, pl. 20, figs. $1-5$.

Tetracyclus lacustris Ralfs, 1843: Hustedt, 1930, Bacill., p. 121, fig. 95; Hustedt, 1931, Kieselalg., II, p. 12, figs. 545a-d; Van Landingham, 1964, p. 22, pl. 48, figs. 4-10.

\section{ACKNOWLEDGMENTS}

The writer thanks the Deep Sea Drilling Project for having given him the opportunity of participating in Leg 19 of the D/V Glomar Challenger cruises, from Kodiak to Yokohama.

The writer thanks Dr. Hans-Joachim Schrader, Geologish-Paläontologisches Institut und Museum der Universität Kiel, for critically reviewing the manuscript and making numerous helpful suggestions. Thanks are due Dr. Kojiro Nakaseko, of the Institute of Geological Sciences, Osaka University, and Dr. Hsin Yi Ling of the Department of Oceanography, University of Washington, for help and encouragement during the investigation. The writer also thanks Dr. Lloyd H. Burckle, Lamont Geological Observatory of Columbia University, for discussions about taxonomic and stratigraphic problems. Acknowledgments are likewise due to many others; Dr. Taro Kanaya, formerly of the Institute of Geology and Paleontology, Tohoku University, supplied the writer with unpublished information concerning his manuscript species and with important literature. The deep-sea core samples used in this study were made available by Dr. Lloyd H. Burckle. Dr. Masao Inoue, of the Ocean Research Institute, University of 
Tokyo, helped the writer in the X-ray analyses of a number of minerals. The writer also thanks his wife Mrs. I. Koizumi, for critically reviewing the manuscript.

\section{REFERENCES}

Akutsu, J., 1964. The geology and paleontology of Schiobara and its vicinity, Tochigi Prefecture. Sci. Rept. Tohoku Univ., 2nd Ser. (Geol.), 35 (3), 211.

Brun, J., 1891. Diatomées espèces nouvelles marines, fossiles ou pelagiques. Mém. Soc. Phys. d'Hist. Nat. Genève. 31 (1), 1.

Brun, J. and Tempère, J., 1889. Diatomées fossiles du Japon. Espèces marines et nouvelles des calcaires argileux de Sendai and de Yedo. Mém. Soc. Phys. d'Hist. Nat. Genève, $30(9), 1$.

Burckle, L. H., 1972. Late Cenozoic planktonic diatom zones from the eastern equatorial Pacific. In First Symposium on Recent and Fossil Marine Diatoms, Simonsen, R. (Ed.). Nova Hedwigia, 39, 217.

Cleve-Euler, A., 1941. Alltertiäre Diatomeen und Silicoflagellaten im Junneren Schwedes. Paleontogr. 92(A), 166.

1951-1955. Die Diatomeen von Schweden und Finnland. Kgl. Svenska Vet.-Akad. Handl, 4th Ser. 5 Vols.

Cupp, E. E., 1943. Marine planktonic diatoms of the West Coast of North America. Bull. Scripps Inst. Oceanogr., Univ. Calif. 5(1), 1.

Donahue, J. G., 1970. Pleistocene Diatoms as Climatic Indicators in North Pacific Sediments. Geol. Soc. Am. Mem. 126, 121.

Dymond, J. R., 1966. Potassium-argon geochronology of deep-sea sediments. Science. 152, 1239.

Greville, R. K., 1865. Descriptions of new and rare diatoms. Trans. Roy. Micros. Soc. London, N. S., Ser. 16, 13, 43.

Hanna, G. D., 1930. Review of the Genus Rouxia. J. Paleontol. 4 (2), 179.

1932. The diatoms of Sharktooth Hill, Kern County, California. Proc. Calif. Acad. Sci. 4th Ser. 20 (6), 161.

, 1970. Fossil diatoms from the Pribilof Islands, Bering Sea, Alaska. Proc. Calif. Acad. Sci. 4th Ser. 37 (5), 167.

Hanna, G. D. and Brigger, A. L., 1966. Fossil diatoms from southern Baja California. Proc. Calif. Acad. Sci. 4th Ser. 30 (15), 285.

Hasle, G. R., 1960. Phytoplankton and cilate species from the tropical Pacific. Skrift. det Norske Videnskaps-Akad. Oslo, Matemat.-Naturv. 2, 1.

1965. Nitzschia and Fragilariopsis species studied in the light and electron microscopes. III. The genus Fragilariopsis. Skrift. det Norske Videnskaps-Akad. Oslo, Matemat.-Naturv. N. S. 21, 1.

1968. The valve processes of the centric diatom genus Thalassiosira. Nytt Magasin for Botanikk. 15 (3), 193.

1972. Fragilariopsis Hustedt as a section of the genus Nitzschia Hassall. In First Symposium on Recent and Fossil Marine Diatoms, Simonsen, R. (Ed.). Nova Hedwigia. 39, 111.

Hays, J. D. and Berggren, W. A., 1971. Quaternary boundaries and correlations. In The Micropaleontology of Oceans, Funnell, B. M. and Riedel, W. R. (Eds.). Cambridge (Cambridge Univ. Press), 669.
Hays, J.D. and Opdyke, N. D., 1967. Antarctic Radiolaria, magnetic reversals and climatic change. Science. 158, 1001 .

Hays, J. D., Saito, T., Opdyke, N. D. and Burckle, L. H., 1969. Pliocene-Pleistocene sediments of the equatorial Pacific: Their paleomagnetic, biostratigraphic, and climatic record. Bull. Geol. Soc. Am. 80, 1481.

Heiden, H. and Kolbe, R. W., 1928. Die Marinen Diatomeen der Deutschen Südpolar-Expedition. 1901-1903. In Deutsche Südpolar-Expedition, 1901-1903. Botanik, Berlin. 8, 449 .

Hendey, N. I., 1964. An introductory account of the smaller algae of British coastal water. Fish. Invest. Ser. 4, Pt. 5, Bacillariophyceae (Diatoms). London. 317 p.

Hustedt, Fr., 1927-1964. Die Kieselalgen Deutschland, Oesterreichs und der Schweiz mit Berucksichtigung der uberigen Lander Europas sowie der angrenzenden Meerese-gebiete. In Dr. Rabenhorst's Kryptogamen-Flora von Deutschland, Oesterreichs und der Schweiz. 7, I., Sect. 1-5, 1-920, 1927-1930; II, Sect. 1-5, 1-736, 1931-1937, III, Sect. 1-3, 1-556, 1961-1964. Leipzig. 1930. Bacillariophyta (Diatomeae), Heft 10. In Pascher, A., Die Süsswasser-Flora Mitteleuropas. Jena. $466 \mathrm{p}$.

, 1958. Diatomeen aus der Antarktis und dem Südatlantik. Deutsche Antarktische Exped. 1938-1939. 2(3), 103.

Ichikawa, W., 1960. On the fossil marine diatoms in the Wakura beds, Noto Peninsula, Japan. Kanazawa Univ., Sci. Rept. 7 (1), 175.

Ikebe, N., Takayanagi, Y., Chiji, M. and Chinzei, K., 1972. Neogene biostratigraphy and radiometric time scale of Japan - an attempt at intercontinental correlation. In Pacific Geology, Minato, M. (Ed.). Tokyo. 4, 39.

Jousé, A. P., 1957. Diatoms in the surface layer of the sediments in the Sea of Okhotsk (in Russian). Tr. Inst. Okeanol., Akad. Nauk S.S.S.R. 22, 164.

1959. The main phases in the development of the flora of marine diatoms in the Far Eastern Seas of the U.S.S.R. at the end of the Tertiary, and during the Quaternary period. Bot. Mag. 44 (1), 44.

, 1961a. Stratigraphy of sediments and paleogeographic conditions of sedimentation in northwestern part of the Pacific Ocean (in Russian). Intern. Geog. Congr., 19th, Stockholm. Izd. Akad. Nauk S.S.S.R. 234. 1961b. Stratigraphy of bottom sediments in northwestern Pacific Ocean (in Russian). Tr. Inst. Geol., Akad. Nauk Estonia S.S.S.R. 8, 183.

1961c. Miocene and Pliocene marine diatoms trom the Far East (in Russian). Bot. Mater. Spor. Rast., Bot Inst., Akad. Nauk S.S.S.R. 16, 59.

1961d. Stratigraphy of sediments and paleogeographical conditions of sediment accumulation in the North Pacific Ocean (abstract). Abstracts of Symposium Papers. 10th Pacific Sci. Congr., Hawaii, 374.

1962. Stratigraphical and paleogeographical studies in the northwestern part of the Pacific Ocean (in Russian). Akad. Nauk S.S.S.R. Moscow. 258 p.

, 1968. New species of diatoms in bottom sediments of the Pacific and the Sea of Okhotsk (in Russian). Nov. Systemat. Plant. non Vascular 1968. Akad. Nauk S.S.S.R. 3, 12.

1969. Diatoms in the sediments of Pleistocene and late Pliocene of the boreal zone of the Pacific Ocean. In Micropaleontology and Organogenous Sedi- 
mentation in the Oceans, Jousé, A. P. (Ed.). Congr. INQUA, 8th. Akad. Nauk S.S.S.R., Moscow, 5. 1971a. Diatoms in Pleistocene sediments from the northern Pacific Ocean. In The Micropaleontology of Oceans, Funnell, B.M. and Riedel, W.R. (Eds.). Cambridge (Cambridge Univ. Press), 407.

, 1971 b. New and important diatom species in the bottom sediments of the Pacific Ocean (in Russian). Nov. Systemat. Plant. non Vascular 1971. Akad. Nauk S.S.S.R. 812 .

Jousé, A.P., Muchina, V.V. and Kozlova, O.G., 1969. Diatoms and silicoflagellates in the surface layer of sediments. In The Pacific Ocean, Microflora and Microfauna in the Recent Sediments of Pacific Ocean, Bezrukov, P.L. (Ed.). Moscow, 7.

Jousé, A.P., Kozlova, O.G. and Muchina, V.V., 1971. Distribution of diatoms in the surface layer of sediment from the Pacific Ocean. In The Micropaleontology of Oceans, Funnel, B. M. and Riedel, W. R. (Eds.). Cambridge (Cambridge Univ. Press), 263.

Kanaya, T., 1957. Eocene diatom assemblages from the Kellogg and "Sidney" shales, Mt. Diablo area, California. Sci. Rept. Tohoku Univ., 2nd Ser. (Geol.). 28, 27. 1959. Miocene diatom assemblages from the Onnagawa Formation and their distribution in the correlative formations in Northeast Japan. Sci. Rept. Tohoku Univ., 2nd Ser. (Geol.). 30, 1.

1961. Characteristics and distribution of diatom thanatocoenoses in Pacific deep-sea cores (abstract). Abstract of Symposium Papers. 10th Pacific Sci. Congr. 375 .

, 1969. Diatom micropaleontology and deep-sea stratigraphy of the North Pacific. La Mer. 7 (3), 183. 1971. Some aspects of pre-Quaternary diatoms in the oceans. In The Micropaleontology of Oceans, Funnell, B.M. and Riedel, W.R. (Eds.). Cambridge (Cambridge Univ. Press), 545.

Kanaya, T. and Koizumi, I., 1966. Interpretation of diatom thanatocoenoses from the North Pacific applied to a study of core V20-130 (Studies of a deep-sea core V20-130. Part IV). Sci. Rept. Tohoku Univ., 2nd Ser. (Geol.). 37 (2), 89.

1970. The progress in the younger Cenozoic diatom stratigraphy in the northern circum-Pacific region. J. Marine Geol. 6 (2), 47.

Kent, D., Opdyke, N.D. and Ewing, M., 1971. Climate change in the North Pacific using ice-rafted detritus as a climatic indicator. Bull. Geol. Soc. Am. 82 (10), 2741.

Koczy, F.F., 1963. Age determination in sediments by natural radioactivity. In The Sea, Hill, M.N. (Ed.). New York (Wiley-Interscience). 3, 816 .

Koizumi, I., 1968. Tertiary diatom flora of Oga Peninsula, Akita Prefecture, Northeast Japan. Sci. Rept. Tohoku Univ., 2nd Ser. (Geol.). 40 (3), 171.

1970a. Diatom thanatocoenoses from the sediment cores in the Japan Sea. J. Marine Geol. 6 (1), 1.

, 1970b. Diatom thanatocoenoses in deep-sea cores from the Philippine Sea. J. Marine Geol. 6 (2), 67.

1972. Marine diatom flora of the Pliocene Tatsunokuchi Formation in Fukushima Prefecture, Northeast Japan. Trans. Proc. Paleont. Soc. Japan, N.S. 86,340 .

$\longrightarrow$, (in press). Diatom ranges and diatom biostratigraphy in Japan. In Neogene Biostratigraphy and Radiometric Time Scale of Japan, Ikebe, N. (Ed.). Geol. Soc. Japan. Mem.
Kolbe, R.W. 1954. Diatoms from equatorial Pacific cores. Rept. Swedish Deep-Sea Exped., 6 (1), 1.

Lisitsyn, A.P., 1971. Distribution of siliceous microfossils in suspension and in bottom sediments. In The Micropaleontology of Oceans, Funnell, B.M. and Riedel, W.R. (Eds.). Cambridge (Cambridge Univ. Press), 173.

Lohman, K.E., 1938. Pliocene diatoms from the Kettleman Hills, California. U.S. Geol. Surv. Prof. Paper 189-C 81. 1941. Diatomaceae, part 3. In Geology and Biology of North Atlantic Deep-Sea Cores, Between Newfoundland and Ireland. (Bradley, W.H. et al.). U.S. Geol. Surv. Prof. Paper 196-B, 5-14 and 55-86.

1948. Middle Miocene diatoms from the Hammond Well. In Cretaceous and Tertiary Subsurface Geology. Maryland Board Nat. Res. 2, 151.

Mann, A., 1907. Report on the diatoms of the "Albatross" voyage in the Pacific Ocean, 1888-1904. U.S. Nat. Herb., Contrib. 10 (5), 221.

McManus, D.A., Burns, R.E. et al., 1970. Initial Reports of the Deep Sea Drilling Project, Volume V. Washington (U.S. Government Printing Office), 611 p.

Mertz, D., 1966. Mikropalaontogische und Sedimentologische Untersuchung der Pisco-Formation Südperus. Paleontogr. 118 (B), 1.

Miller, U., 1964. Diatom floras in the Quaternary of the Gota River Valley (Western Sweden). Sveriges Geol. Undersokning. 44, 1.

Muchina, V.V., 1965. New species of diatoms from the bottom sediments of the equatorial region of the Pacific (in Russian). Nov. Systemat. Plant. non Vascular 1965. Akad. Nauk S.S.S.R. 11, 22.

1969. Biostratigraphy of sediments and questions of paleogeography of the tropical region of the Pacific and Indian Oceans. In Micropaleontology and Organogenous Sedimentation in the Oceans, Jousé, A.P. (Ed.). 8th Congr. INQUA. Akad. Nauk S.S.S.R., Moscow, 52.

- 1971. Problems of diatom and silicoflagellate Quaternary stratigraphy in the equatorial Pacific Ocean. In The Micropaleontology of Oceans, Funnell, B.M. and Riedel, W.E. (Eds.), Cambridge (Cambridge Univ., Press), 423.

Nakaseko, K., 1959. Applied micropaleontological research by means of radiolarian fossil in the oil Tertiary, Japan. Part 1; Method, geological note and radiolarian assemblage in Akita sedimentary basin. Sci. Rept. College Gen. Educa. Osaka Univ. 8, 113.

1960. Applied micropaleontological research by means of radiolarian fossil in the oil Tertiary, Japan, Part 2; Radiolarian assemblage in Yamagata basin, discussion and conclusion. Sci. Rept. College Gen. Educa. Osaka Univ. 9, 149.

Nakaseko, K., Koizumi, I., Sugano, K. and Maiya, S., 1972a. Microbiostratigraphy of the Neogene formations in the Nadaura area, Toyama Prefecture, Japan. J. Geol. Soc. Japan. 78 (5), 253.

Nakaseko, K. Sugano, K. and Ieda, K., 1972b. Some problems concerning the radiolarian stratigraphy in the Niigata sedimentary basin, Japan. J. Japanese Assn. Petrol. Tech. 37 (2). 7.

Ninkovich, D., Opdyke, B.C., Heezen, B.C. and Foster, J.H., 1966. Paleomagnetic stratigraphy, rates of deposition and tephrachronology in North Pacific deep-sea sediments. Earth Planet. Sci. Letters 1, 476.

Pantocsek, J., 1886-1892. Beiträge zur Kenntniss der Fossilen Bacillarien Ungarns. Berlin. 3, Parts. 
Patrick, R. and Reimer, C.W., 1966. The diatoms of the United States, exclusive of Alaska and Hawaii. Acad. Nat. Sci. Philadelphia, Monogr. 13. 1, 688.

Rattray, J., 1890. A revision of the genus Actinocyclus Ehr. J. Quekett Micros. Club, 2nd Ser. 4, 137.

Riedel, W.R., 1959. Siliceous organic remains in pelagic sediments. In Silica in Sediments, Ireland, H.A. (Ed.). Am. Assoc. Petrol. Geologists. 81.

Riedel, W.R. and Sanfilippo, A., 1970. Radiolaria, Leg 4, Deep Sea Drilling Project. In Bader, R.G., Gerard, R.D. et al., 1970. Initial Reports of the Deep Sea Drilling Project, Volume IV. Washington (U.S. Government Printing Office), 503.

Saito, T., 1963. Miocene planktonic Foraminifera from Honshu, Japan. Sci. Rept. Tohoku Univ., 2nd Ser. (Geol.). 35 (2), 124.

Sawamura, K., 1963a. On the correlation of the Miocene of the Joban, Tomamae coal field and that of east Hokkaido. Bull. Geol. Surv. Japan. 14 (1), 91. 1963b. Fossil diatoms in the Oidawara Formation of the Mizunami Group. Bull. Geol. Surv. Japan. 14 (5), 387 .

Sawamura, K. and Yamaguchi, S., 1961. Correlation of the hard shales by diatoms in the Abashiri-Urahoro area, east Hokkaido. Bull. Geol. Surv. Japan. 12 (11), 885. , 1963. Subdivision of Miocene by fossil diatoms in the Tsubetsu area, east Hokkaido. Bull. Geol. Surv. Japan, 14 (10), 777.

Seczkina, T. V., 1959. Diatoms in a long core of bottom sediments from the Sea of Japan (in Russian). Dok. Akad. Nauk S.S.S.R. 126 (1), 171.

Schmidt, A., 1874-1959. Atlas der Diatomaceen-Kunde. 5 Vols.

Sheshukova-Poretzkaya, V.S., 1956. On the origin of fossil Rouxia Brun and Heribaud (Bacillariopyta) (in Russian). Bot. Matr. Bot. Inst. Akad. Nauk S.S.S.R. 11, 64.
1962. New and rare diatoms from formations of Sakhalin (in Russian). Leningrad Gos. Univ., Vest. no. 313, Biol. Inst. Ser. Biol., Nauk. Vup. 49, 203.

1964. New and rare marine diatoms of the Neogene of Sakhalin and Kamtchatka (in Russian). Nov. Systemat. Plant. non Vascular 1964. Akad. Nauk S.S.S.R. 10, 69. 1967. Neogene marine diatoms of Sakhalin and Kamıschatka (in Russian). Izd. Leningrad Univ. 327 p. 1968. Neogene Marine Bacillariophyta of the Far East. In Fossil Diatoms of the Soviet Union (in Russian), Jousé, A.P. (Ed.). Izd. Akad. Nauk S.S.S.R. Moscow, 26.

Shinbo, K. and Maiya, S., 1969, Neogene Tertiary planktonic Foraminiferal zonation in the Japanese oil producing provinces. Rept. Japanese Delegation, 4th ECAFE Petrol. Sympo. 1.

Simonsen, R. and Kanaya, T. 1961. Note on the marine species of the diatom genus Denticula Kütz. Int. Revue. Ges. Hydrobiol. 46, 498.

Van Heurck, H., 1880-1885. Synopsis des diatomées de Belgique. Anvers. 235 p.

Van Landingham, S.L., 1964. Miocene non-marine diatoms from the Yakima region in south central Washington. Nova Hedwigia. 14, 1 .

1967. Paleoecology and microfloristics of Miocene diatomites from the Otis basin-Juntura region of Harney and Malheur Counties, Oregon. Nova Hedwigia. 26,1 .

Vecshina, V.N., 1968. Middle Miocene assemblage of Bacillariophyta of Kurile Islands. In Fossil diatoms of the Soviet Union (in Russian). Jousé, A.P. (Ed.). Izd. Akad. Nauk S.S.S.R. Moscow. 37.

Vergunov, G.P. and Pryalukhina, A. F., 1965. Miocene sediments of the Kurile Islands (in Russian). Dok. Akad. Nauk S.S.S.R. 164 (6), 1359.

Wornardt, W.W., Jr., 1967. Miocene and Pliocene marine diatoms from California. Calif. Acad. Sci., Occasional Paper 63, 1. 

PLATE 1

Figures 1-2 Actinocyclus curvatulus Jan. Slide no. $431,42 \mu$ in diameter, from 187-1(CC) (Lst), Denticula seminae Zone to Actinocyclus oculatus Zone, Pleistocene. $\times 800$.

Figures 3-4 Actinocyclus curvatulus Jan. Slide no. $431,57 \mu$ in diameter, from 187-1(CC) (Lst), Denticula seminae Zone to Actinocyclus oculatus Zone, Pleistocene. $\times 800$.

Figures 5-6 Actinocyclus curvatulus Jan. Slide no. 431, $61 \mu$ in diameter, from 187-1(CC) (Lst), Denticula seminae Zone to Actinocyclus oculatus Zone, Pleistocene. $\times 800$.

Figures 7-8 Actinocyclus divisus (Grun.) Hust. Slide no. 513, $43 \mu$ in diameter, from 189-4-2(10-12 cm), Rhizosolenia curvirostris Zone, middle Pleistocene. X1000.

Figures 9-10 Actinocyclus divisus (Grun.) Hust. Slide no. 888, 46 $\mu$ in diameter, from 193-1-1(120-122 cm), Denticula seminae Zone, upper Pleistocene. $\times 1000$.

Figures 11-12 Actinocyclus divisus (Grun.) Hust. Slide no. 431, 60 $\mu$ in diameter, from 187-1(CC) (Lst), Denticula seminae Zone to Actinocyclus oculatus Zone, Pleistocene, $\times 800$.

Figure 13 Actinocyclus ingens Ratt. Slide no. $831,36 \mu$ in diameter, from 192-24-2(20-22 cm), Denticula hustedtii Zone, upper Miocene. X1000.

Figure 14 Actinocyclus ingens Ratt. Slide no. $837,44 \mu$ in diameter, from 192-25-1(80-82 cm), Denticula lauta Zone, middle Miocene. $\times 1000$. 
Plate 1
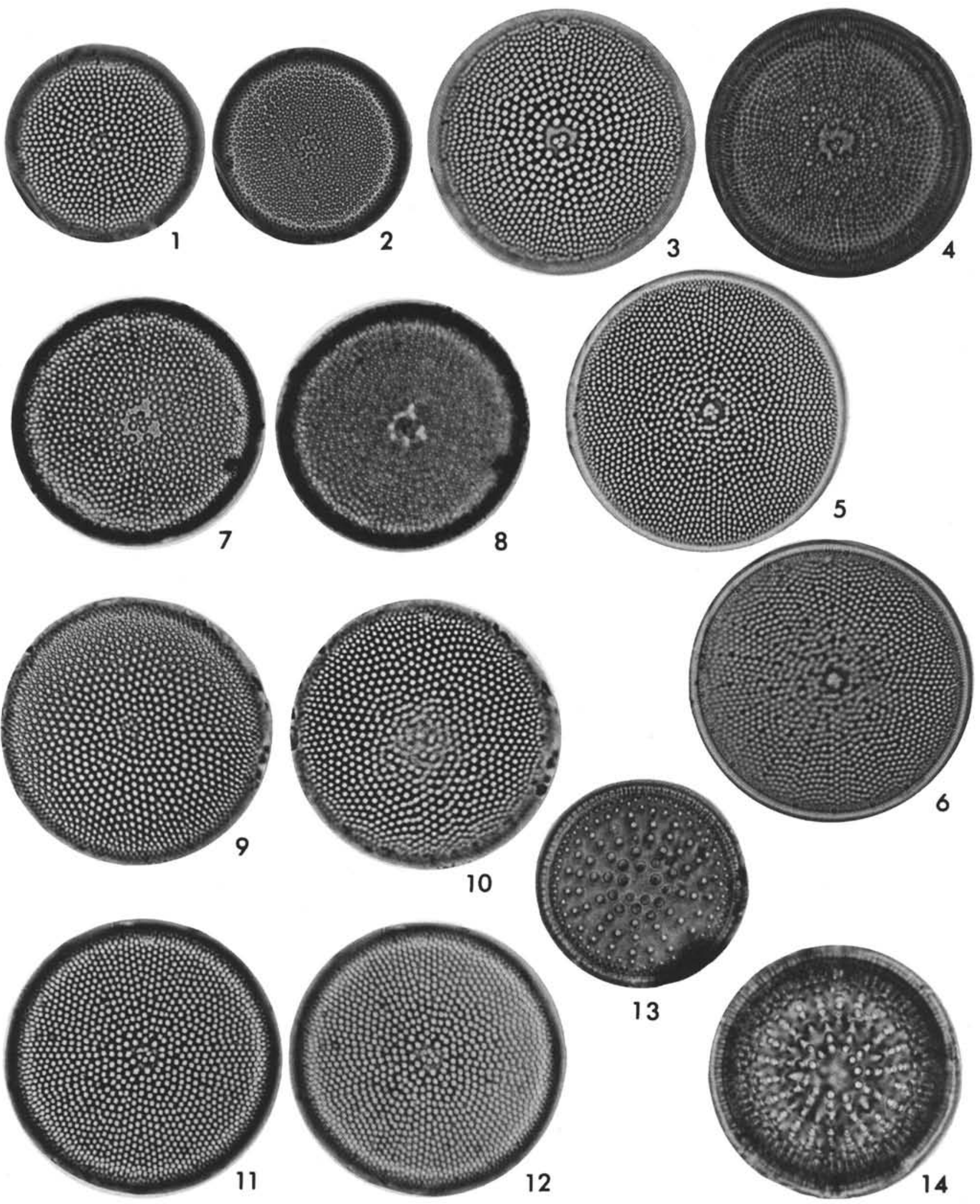


\section{PLATE 2}

Figures 1-2 Actinocyclus ingens Ratt. Slide no. $163,57 \mu$ in diameter, from 183-20-1(140-142 cm), Denticula lauta Zone, middle Miocene. $\times 800$.

Figure 3 Actinocyclus ochotensis Jousé. Slide no $627,31 \mu$ in diameter, from 190-14-2, 100-102 cm, Denticula kamtschatica Zone, upper Miocene. $\times 1000$.

Figures 4-5 Actinocyclus ochotensis Jouse. Slide no 431, $42 \mu$ in diameter, from 187-1(CC) (Lst), Denticula seminae Zone to Actinocyclus oculatus Zone, Pleistocene. X 1000 .

Figures 6-7 Actinocyclus ochotensis Jousé. Slide no. $261,45 \mu$ in diameter, from 184-9(CC). Thalassiosira zabelinae Zone, upper Pliocene. $\times 1000$.

Figure $8 \quad$ Actinocyclus oculatus Jousé. Slide no. $128,28 \mu$ in diameter, from 183-9(CC), Actinocyclus oculatus Zone, lower Pleistocene. $\times 1000$.

Figure 9 Actinocyclus oculatus Jousé. Slide no. 126, $37 \mu$ in diameter, from 183-9-3(130-132 cm), Actinocyclus oculatus Zone, lower Pleistocene, $\times 1000$.

Figure 10 Coscinodiscus endoi Kanaya. Slide no. $840,23 \mu$ in diameter, from 192-25(CC), Denticula lauta Zone, middle Miocene. $\times 1000$.

Figures 11-12 Coscinodiscus excentricus Ehr. Slide no. 313, $68 \mu$ in diameter, from 186-1-1(120-122 cm), Denticula seminae Zone, upper Pleistocene. $\times 1000$.

Figures 13-14 Coscinodiscus excentricus Ehr. var. fasciculata Hust. Slide no. 565, 50 $\mu$ in diameter, from 190-2-1(25-27 $\mathrm{cm})$ Denticula seminae Zone, upper Pleistocene. $\mathrm{X} 1000$.

Figures 15-16 Coscinodiscus excentricus Ehr. var. fasciculata Hust. Slide no. $101,35 \mu$ in diameter, from Denticula seminae Zone, upper Pleistocene. $\times 1000$. 
PLATE 2
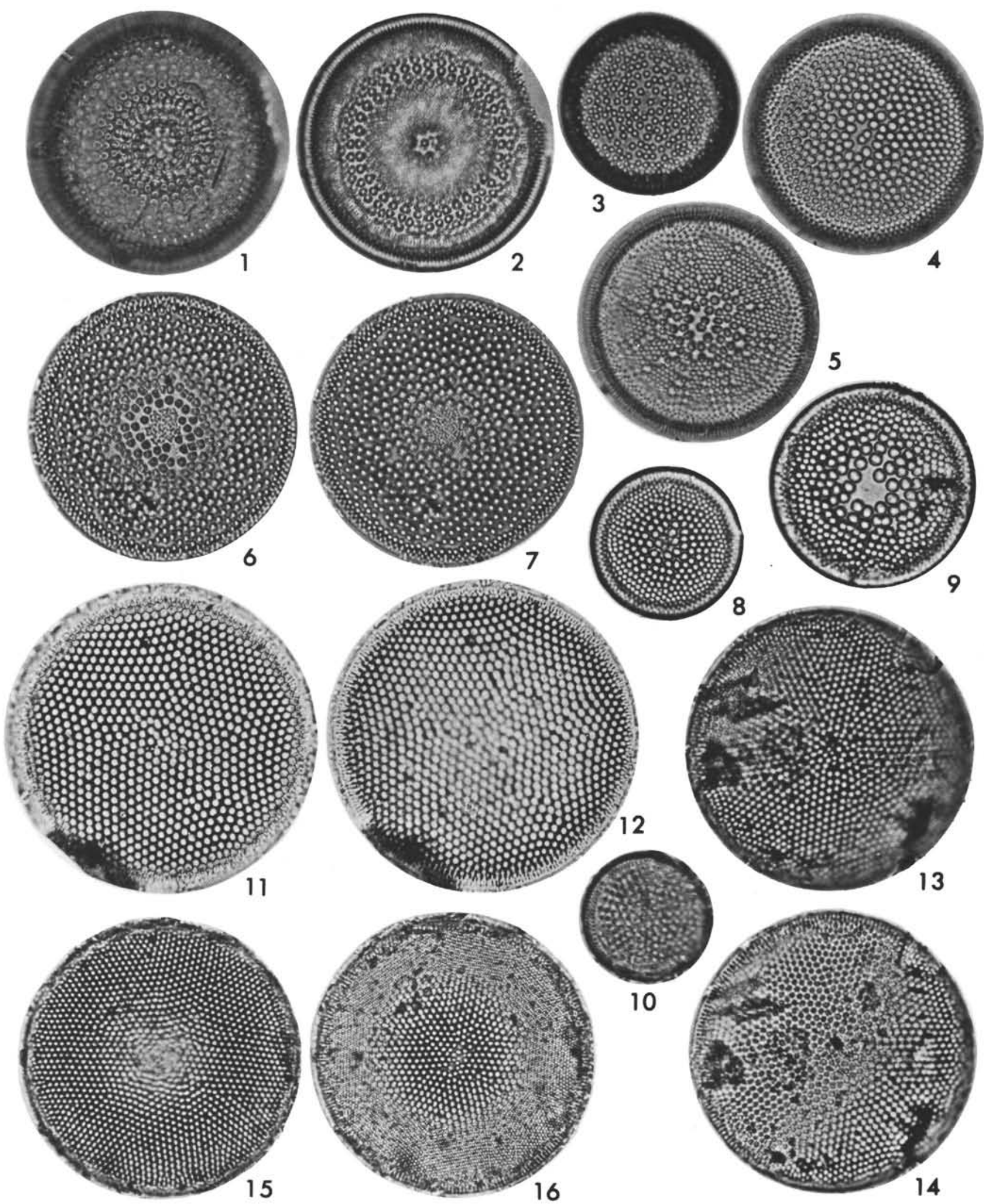


\section{PLATE 3}

Figures 1-2 Coscinodiscus excentricus Ehr. var. jousei Kanaya. Slide no. $664,33 \mu$ in diameter, from 191-5-6(70-72 $\mathrm{cm})$, Rhizosolenia curvirostris Zone, middle Pleistocene. $\times 1000$.

Figures 3-4 Coscinodiscus excentricus Ehr. var. jousei Kanaya. Slide no. $313,44 \mu$ in diameter, from 186-1-1(120-122 $\mathrm{cm})$, Denticula seminae Zone, upper Pleistocene. $\times 1000$.

Figures 5-6 Coscinodiscus excentricus Ehr. var. jousei Kanaya. Slide no. 502, $40 \mu$ in diameter, from 189-1-1(71-73 cm), Denticula seminae Zone, upper Pleistocene. $\times 1000$.

Figures 7-8 Coscinodiscus excentricus Ehr. var. leasareolatus Kanaya. Slide no. $899,53 \mu$ in diameter, from 193-3-1(101-103 cm), Rhizosolenia curvirostris Zone, middle Pleistocene. $\times 800$.

Figures 9-10 Coscinodiscus excentricus Ehr. var. leasareolatus Kanaya. Slide no. $313,53 \mu$ in diameter, from 186-1-1(120-122 cm), Denticula seminae Zone, upper Pleistocene. $\times 1000$.

Figure 11 Coscinodiscus excentricus Ehr. var. leasareolatus Kanaya. Slide no. $450,59 \mu$ in diameter, from 188-3-2(130-132 cm), Denticula seminae Zone, upper Pleistocene. $\times 800$.

Figures 12-13 Coscinodiscus marginatus Ehr. forma fossilis Jousé. Slide no. 436, $63 \mu$ in diameter, from 187-3(CC) (Lst), Denticula kamtschatica Zone, upper Miocene. $\times 800$.

Figure 14 Coscinodiscus marginatus Ehr. forma fossilis Jousé. Slide no. $157,90 \mu$ in diameter, from 183-18-2(80-82 $\mathrm{cm})$, Denticula kamtschatica Zone, upper Miocene. $\times 600$. 
PLATE 3
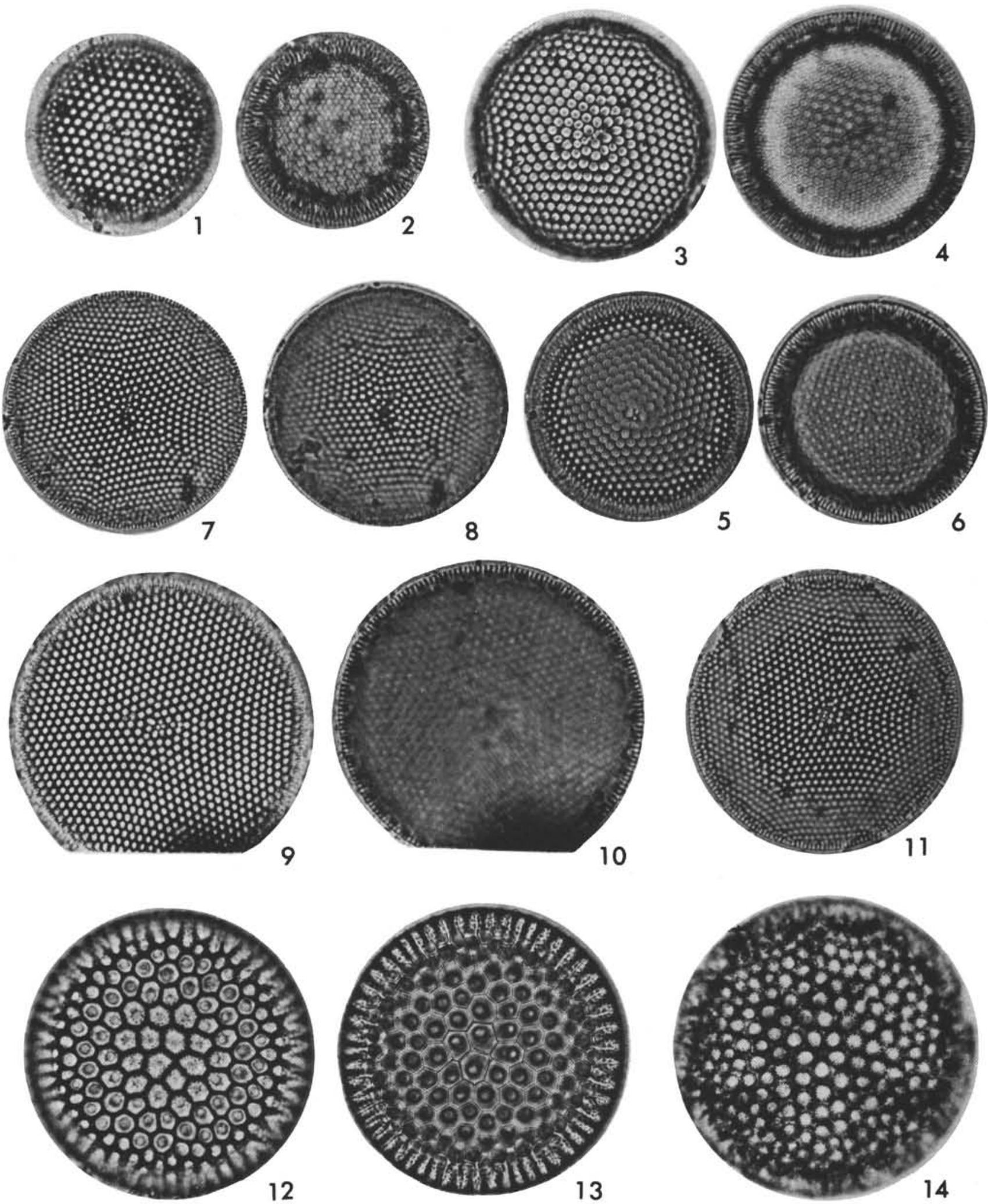


\section{PLATE 4}

Figures 1-2 Coscinodiscus pustulatus Mann. Slide no. 213,60 $\mu$ in diameter, from 184-2-3(130-132 cm), Thalassiosira zabelinae Zone, upper Pliocene. X800.

Figures 3-4 Coscinodiscus pustulatus Mann. Slide no. 532, $43 \mu$ in diameter, from 189-9-1(100-102 cm), Thalassiosira zabelinae Zone, upper Pliocene. $\times 1000$.

Figure 5 Coscinodiscus stellaris Rop. var. symbolophora (Grun.) Joerg. Slide no. 398, $49 \mu$ in diameter, from 186-23-3(50-52 cm), Denticula seminae-Denticula kamtschatica Zone, lower Pliocene. $\times 800$.

Figure 6 Coscinodiscus stellaris Rop. var. symbolophora (Grun.) Joerg. Slide no. 823, 26 $\mu$ in diameter, from 192-22-1(100-102 cm), Denticula kamtschatica Zone, upper Miocene. X1200.

Figures 7-8 Cosmiodiscus insignis Jousé. Slide no. 414, 39 $\mu$ in diameter, from 186-24(CC), Denticula seminaeDenticula kamtschatica Zone, lower Pliocene. X1000.

Figure 9 Cosmiodiscus insignis Jousé. Slide no. 414, $35 \mu$ in diameter, from 186-24(CC), Denticula seminaeDenticula kamtschatica Zone, lower Pliocene. $\times 1000$.

Figures 10-11 Cosmiodiscus insignis Jousé. Slide no. 412, 35 $\mu$ in diameter, from 186-24(CC), Denticula seminaeDenticula kamtschatica Zone, lower Pliocene. $\times 1000$.

Figures 12-13 Cosmiodiscus intersectus Jousé. Slide no. 414, 52 $\mu$ in diameter, from 186-24(CC), Denticula seminaeDenticula kamtschatica Zone, lower Pliocene. $\times 800$.

Figure $14 \quad$ Pseudopodosira elegans Sheshuk. Slide no. 648, $25 \mu$ in diameter, from 191-2-1(50-52 cm), Denticula seminae Zone, upper Pleistocene. $\times 800$.

Figures 15-16 Porosira glacialis (Grun.) Joerg. Slide no. 115, 34 $\mu$ in diameter, from 183-6-3(80-82 cm), Rhizosolenia curvirostris Zone, middle Pleistocene. $\times 1000$.

Figures 17-18 Porosira glacialis (Grun.) Joerg. Slide no. 391, 30 $\mu$ in diameter, from 186-22(CC), Denticula seminaeDenticula kamtschatica Zone, lower Pliocene. X1200 
PLATE 4
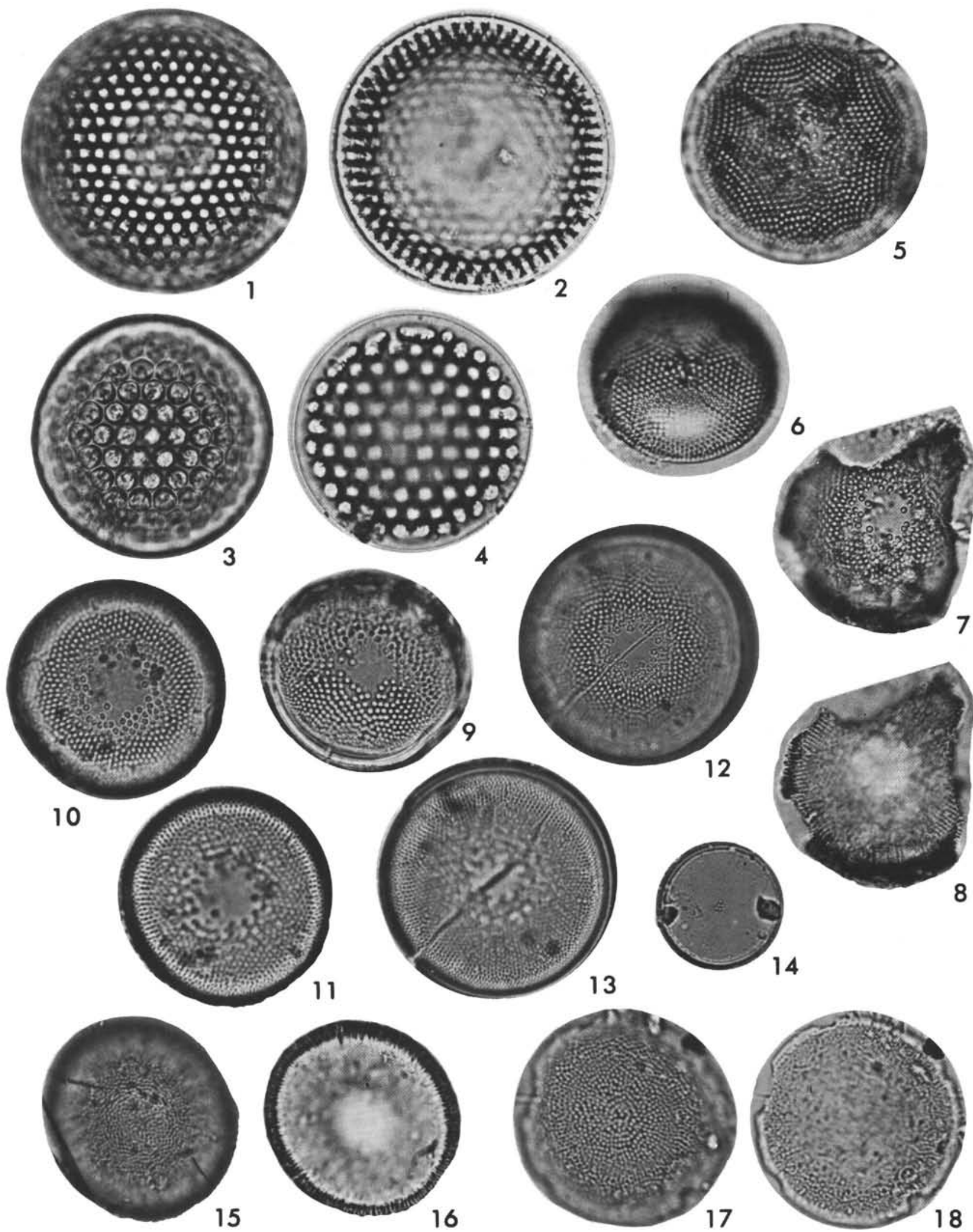
Figures 1-2 Denticula seminae Simonsen and Kanaya. Slide no. $313,19 \mu$ in length, from $186-1-1(120-122 \mathrm{~cm})$ Denticula seminae Zone, upper Pleistocene. $\times 1200$.

Figures 3-4 Denticula seminae Simonsen and Kanaya. Slide no. $443,28 \mu$ in length, from 188-1-1(58-60 cm), Denticula seminae Zone, upper Pleistocene. $\times 1200$.

Figures 5-6 Denticula seminae Simonsen and Kanaya. Slide no. $443,41 \mu$ in length, from $188-1-1(58-60 \mathrm{~cm})$, Denticula seminae Zone, upper Pleistocene. $\times 1200$.

Figures 7-9 Denticula seminae Simonsen and Kanaya. Slide no. $758,26 \mu$ in length, from $192-8-4(70-72 \mathrm{~cm})$, Thalassiosira zabelinae Zone, upper Pliocene. $\times 1200$.

Figures 10-11 Denticula seminae Simonsen and Kanaya. Slide no. $473,21 \mu$ in length, from $188-9-1(40-42 \mathrm{~cm})$, Thalas siosira zabelinae Zone, upper Pliocene. X1200.

Figures 12-13 Denticula seminae Simonsen and Kanaya. Slide no. $473,17 \mu$ in length, from $188-9-1(40-42 \mathrm{~cm})$, Thalas siosira zabelinae Zone, upper Pliocene. X1200.

Figure 14 Denticula kamtschatica Zabelina. Slide no. 433, $22 \mu$ in length, from 187-1(CC) (Lst), Denticula seminae Zone to Actinocyclus oculatus Zone, Pleistocene. $\mathrm{X} 1200$.

Figure 15 Denticula kamtschatica Zabelina. Slide no. $144,17 \mu$ in length, from 183-13-4(0-2 cm), Denticula seminaeDenticula kamtschatica Zone, lower Pliocene.X1200.

Figures 16-17 Denticula kamtschatica Zabelina. Slide no. 151, 32 $\mu$ in length, from 183-17-1(80-82 cm), Denticula kamtschatica Zone, upper Miocene. $\times 1200$.

Figures 18-19 Denticula hustedtii Simonsen and Kanaya. Slide no. $831,29 \mu$ in length, from $192-24-2(20-22 \mathrm{~cm})$, Denticula hustedtii Zone, upper Miocene. $\times 1200$.

Figures 20-21 Denticula hustedtii Simonsen and Kanaya. Slide no. $831,36 \mu$ in length, from $192-24-2(20-22 \mathrm{~cm})$, Denticula hustedtii Zone, upper Miocene. $\times 1000$.

Figures 22-23 Denticula hustedtii Simonsen and Kanaya. Slide no. $162,22 \mu$ in length, from 183-19(CC), Denticula lauta Zone, middle Miocene. $\times 1200$.

Figures 24-25 Denticula lauta Bail. Slide no. 160, 26 $\mu$ in length, from 183-19-2 $(80-82 \mathrm{~cm})$, Denticula lauta Zone, middle Miocene. $\times 1200$.
Figure 26

Figures 27-28

Figure 29

Figure 30

Figure 31

Figure 32

Figure 33

Figure 34

Figure 35

Figure 36

Figures 37-38 Rhizosolenia sp.c. Slide no. 888 , broken specimen, from 193-1-1(120-122 cm), Denticula seminae Zone, upper Pleistocene. $\times 1200$.

Figure 39 Rhizosolenia sp.e. Slide no. 816 , broken specimen, from 192-20-1(30-32 cm), Denticula kamtschatica Zone, upper Miocene. $\times 1000$.

Figure 40-41 Rhizosolenia sp.2. Slide no. 404, broken specimen, from 186-23(CC), Denticula seminae-Denticula kamtschatica Zone, lower Pleistocene. X1200. 
PLATE 5

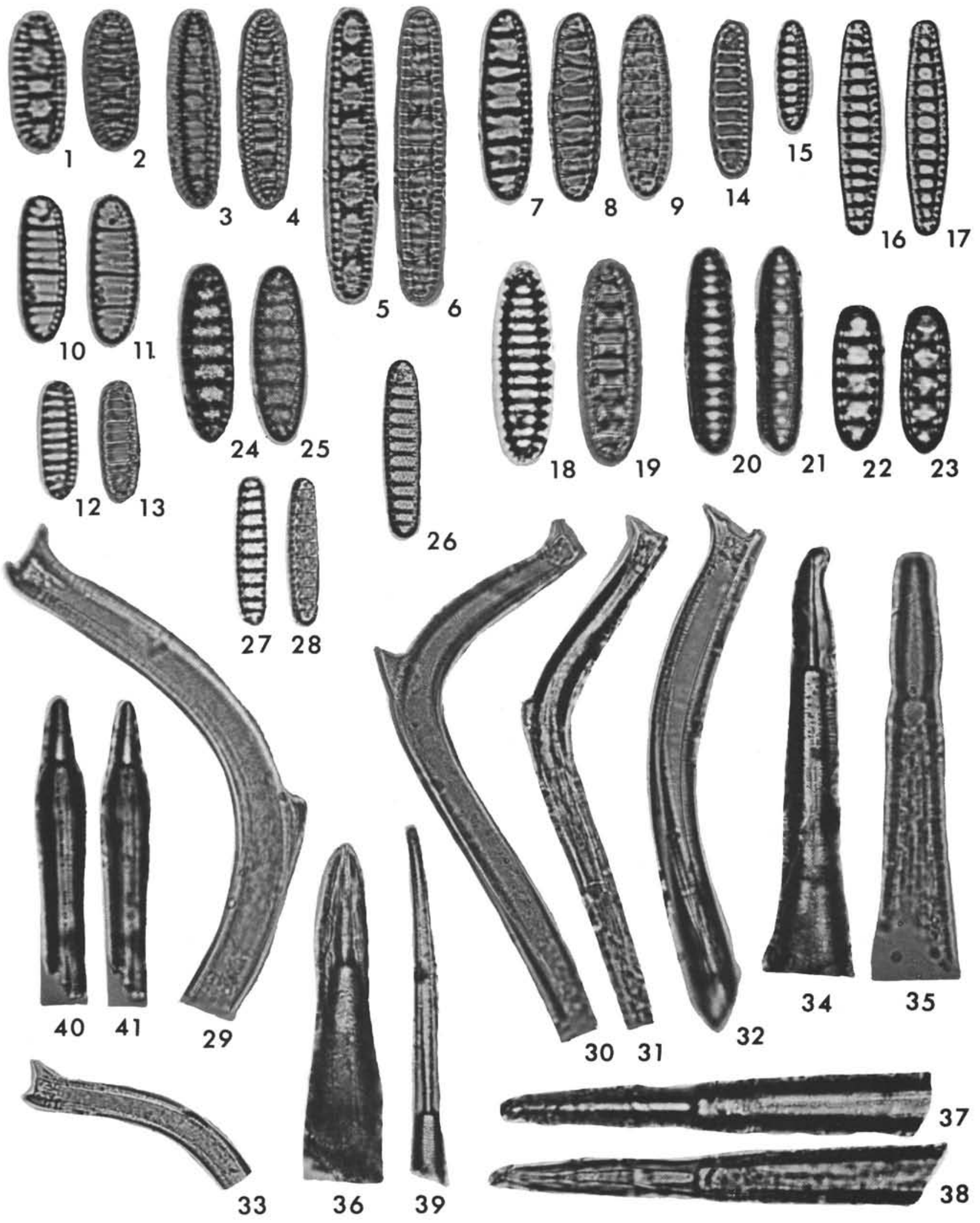




\section{PLATE 6}

Figures 1-2 Stephanopyxis horridus Koizumi. Slide no. $540,41 \mu$ in diameter, from 189-10(CC), Thalassiosira zabelinae Zone, upper Pliocene.X1000.

Figures 3-4 Stephanopyxis horridus Koizumi. Slide no. 522, $45 \mu$ in diameter, from 189-6-1(84-86 cm), Thalassiosira zabelinae Zone, upper Pliocene. $\times 1000$.

Figures 5-6 Stephanopyxis inermis Jousé. Slide no. 522, $27 \mu$ in diameter, from 189-6-1 $(84-86 \mathrm{~cm})$, Thalassiosira zabelinae Zone, upper Pliocene. $\times 1000$.

Figures 7-8 Stephanopyxis inermis Jousé. Slide no. $766,28 \mu$ in diameter, from 192-9(CC), Thalassiosira zabelinae Zone, upper Pliocene. $\times 1000$.

Figures 9-10 Stephanopyxis inermis Jouse. Slide no. 522, $32 \mu$ in diameter, from 189-6-1(84-86 cm), Thalassiosira zabelinae Zone, upper Pliocene. X1000.

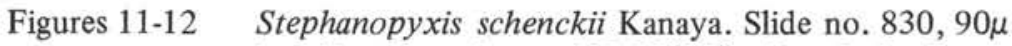
in diameter, from 192-23(CC), Denticula kamtschatica Zone, upper Miocene. $\times 500$ on the Figure $11, \times 1000$ on the Figure 12.

Figure 13 Stephanopyxis turris (Grev. and Arn.) Ralfs. Slide no. $414,21 \mu$ in diameter, from 186-24(CC), Denticula seminae-Denticula kamtschatica Zone, lower Pliocene. $\times 1000$.

Figure 14 Stephanopyxis turris (Grev. and Arn.) Ralfs. Slide no. $414,22 \mu$ in diameter, from 186-24(CC), Denticula seminae-Denticula kamtschatica Zone, lower Pliocene. $\times 1000$.

Figures 15-16 Stephanopyxis turris (Grev. and Arn.) Ralfs. Slide no. $437,54 \hat{\mu}$ in diameter, from 187-3(CC) (Lst), Denticula kamtschatica Zone, upper Miocene. X800.

Figure 17 Synedra Jouseana Sheshuk. Slide no. 837, $69 \mu$ in length, from 192-25-1(80-82 cm), Denticula lauta Zone, middle Miocene. $\times 1000$. 
Plate 6
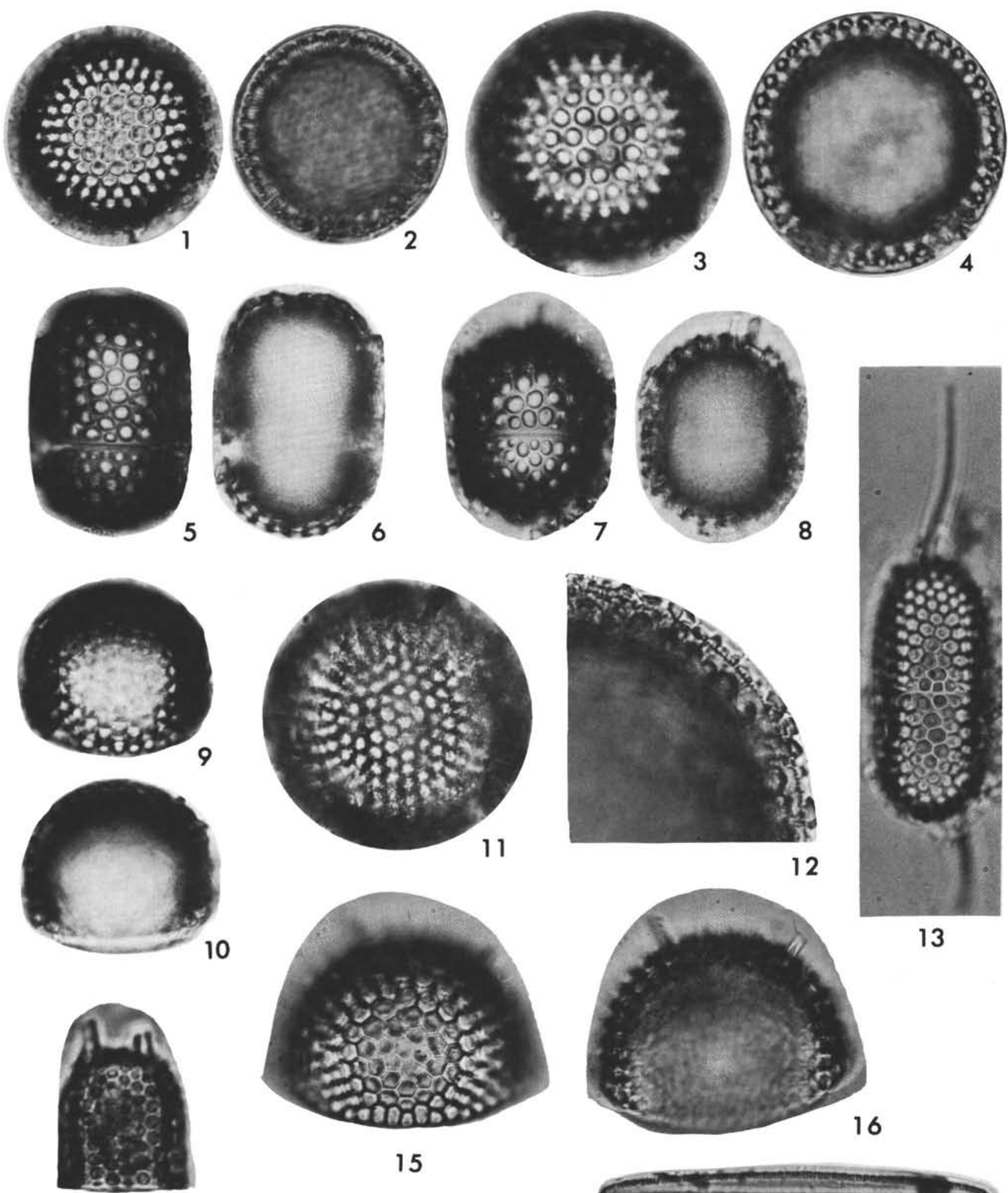

15

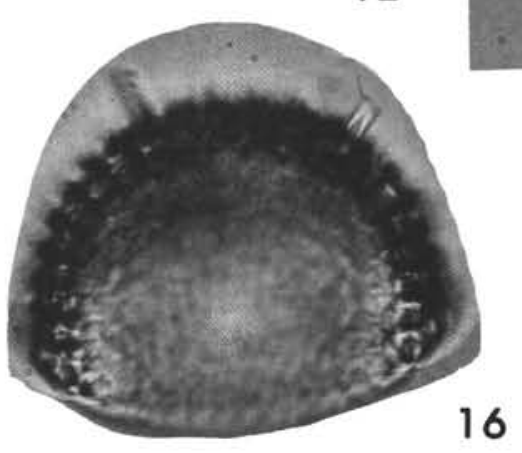

13 
Figure 1 Fragilariopsis cylindrus (Grun.) Helmck and Krieger. Slide no. $644,53 \mu$ in length, from 191-1(CC), Denticula seminae Zone, upper Pleistocene. $\times 1000$.

Figure 2 Fragilariopsis cylindrus (Grun.) Helmck and Krieger. Slide no. $772,25 \mu$ in length, from 192-10-4(30-32 $\mathrm{cm})$, Denticula seminae-Denticula kamtschatica Zone, lower Pliocene. $\times 1200$.

Figure 3 Kisseleviella carina Sheshuk. Slide no. $404,19 \mu$ in length, from 186-23(CC), Denticula seminaeDenticula kamtschatica Zone, lower Pliocene. X1000.

Figure 4 Kisseleviella carina Sheshuk. Slide no. $404,26 \mu$ in length, from 186-23(CC), Denticula seminaeDenticula kamtschatica Zone, lower Pliocene. X1200.

Figure 5 Mediaria splendida Sheshuk. Slide no. 163, broken specimen, from 183-20-1(140-142 cm), Denticula lauta Zone, middle Miocene. $\times 1000$.

Figure 6 Mediaria splendida Sheshuk. Slide no. 163, broken specimen, from 183-20-1(140-142 cm), Denticula lauta Zone, middle Miocene. $\times 1000$.

Figures 7-8 Goniothecium tenue Brun. Slide no. $818,49 \mu$ in length, from 192-20(CC), Denticula kamtschatica Zone, upper Miocene. X1000.

Figures 9 Goniothecium tenue Brun. Slide no. $404,49 \mu$ in length, from 186-23(CC), middle Miocene. $\times 1000$.

Figure 10 Rouxia peragalli Brun and Herib. Slide no. 825, broken specimen, from 192-22(CC), Denticula kamtschatica Zone, upper Miocene. $\times 1000$.

Figure 11 Rouxia peragalli Brun and Herib. forma califormica (Perag.) Sheshuk. Slide no. 825, broken specimen, from 192-22(CC), Denticula Kamtschatica Zone, upper Miocene. $\times 1000$.

Figure 12 Thalassiosira antiqua (Grun.) C1. Slide no. $414,43 \mu$ in diameter, from 186-24(CC), Denticula seminaeDenticula kamtschatica Zone, lower Pliocene. X1000.

Figures 13-15 Thalassiosira convexa Much. Slide no. $153,26 \mu$ in diameter, from 183-17-3(80-82 cm), Denticula kamtschatica Zone, upper Miocene. X1200.
Figure 16

Figures 17-18

Figures 19-20

Figure 21

Figure 22

Figures 23-24

Figure 25

Figure 26

Figure 27

Figure 28

Figure 29
Thalassiosira decipiens (Grun.) Joerg. Slide no. 437, $18 \mu$ in diameter, from 187-3(CC) (Lst), Denticula kamtschatica Zone, upper Miocene. X1200.

Thalassiosira decipiens (Grun.) Joerg. Slide no. 440, $18 \mu$ in diameter, from 187-3(CC) (Lst), Denticula kamtschatica Zone, upper Miocene. X1200.

Thalassiosira gravida C1. Slide no. $658,52 \mu$ in diameter, from 191-4.5(110-112 cm), Denticula seminae Zone, upper Pleistocene. $\times 800$.

Thalassiosira gravida C1. Slide no. $255,36 \mu$ in diameter, from 185-1-1(20-22 cm), Denticula seminae Zone, upper Pleistocene. X 1000.

Thalassiosira gravida $\mathrm{Cl}$. forma fossilis Jousé. Slide no. $271,45 \mu$ in diameter, from $185-6-2(140-142 \mathrm{~cm})$, Actinocyclus oculatus Zone, lower Pleistocene. $\mathrm{X} 1000$.

Thalassiosira gravida $\mathrm{C} 1$. forma fossilis Jousé. Slide no. $522,34 \mu$ in diameter, from $189-6-1(84-86 \mathrm{~cm})$ Thalassiosira zabelinae Zone, upper Pliocene. X1000.

Thalassiosira nidulus (Temp. and Brun) Jousé. Slide no. $437,24 \mu$ in diameter, from 187-3(CC) (Lst), Denticula kamtschatica Zone, upper Miocene. X1000.

Thalassiosira nidulus (Temp. and Brun) Jousé. Slide no. $414,29 \mu$ in diameter, from 186-24(CC), Denticula seminae-Denticula kamtschatica Zone, lower Pliocene. $\times 1000$.

Thalassiosira oestrupi (Ostf.) Pr. Slide no. 897, $26 \mu$ in diameter, from 193-2(CC), Rhizosolenia curvirostris Zone, middle Pleistocene. X1000.

Thalassiosira lineata Jousé. Slide no. 502, $20 \mu$ in diameter, from 189-1-1(71-73 cm), Denticula seminae Zone, upper Pleistocene. X1200.

Thalassiosira lineata Jousé. Slide no. $515,32 \mu$ in diameter, from 189-4(CC), Actinocyclus oculatus Zone, lower Pleistocene. X1000. 
PLATE 7
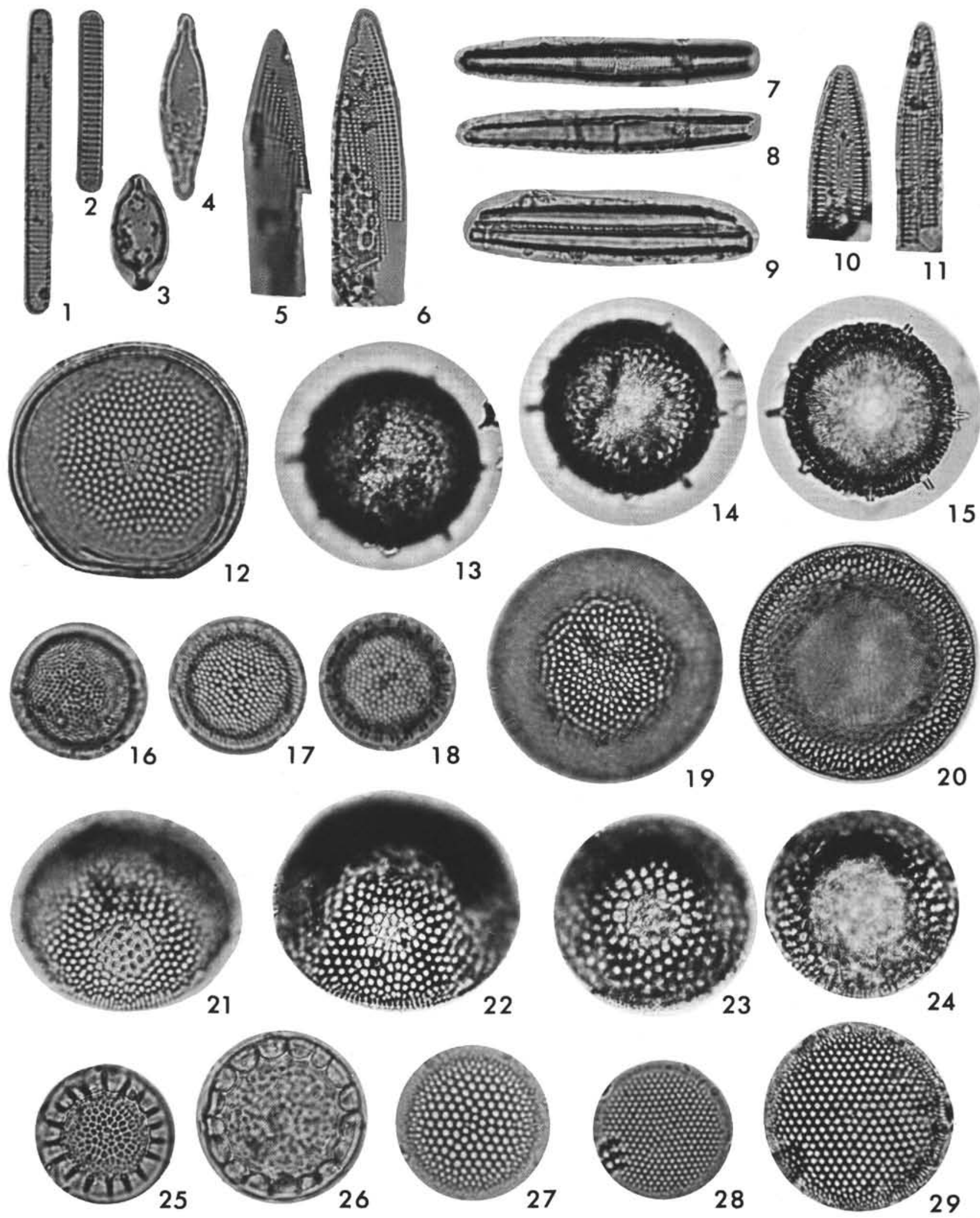


\section{PLATE 8}

Figure 1 Thalassiosira hyalina (Grun.) Grun. Slide no. 658, $26 \mu$ in diameter, from 1914-5(110-112 cm), Denticula seminae Zone, upper Pleistocene. $\times 1000$.

Figure 2 Thalassiosira hyalina (Grun.) Grun. Slide no. 648, $54 \mu$ in diameter, from 191-2-1(50-52 cm), Denticula seminae Zone, upper Pleistocene. $\times 800$.

Figure 3 Thalassiosira kryophila (grun.) Joerg. Slide no. 502, $31 \mu$ in diameter, from 189-1-1(71-73 cm), Denticula seminae Zone, upper Pleistocene. $\times 1000$.

Figure 4 Thalassiosira nordenskiöldi $\mathrm{Cl}$. Slide no. $658,28 \mu$ in diameter, from 1914-5(110-112 cm), Denticula seminae Zone, upper Pleistocene. $\times 1000$.

Figures 5-6 Thalassiosira undulosa (Mann) Sheshuk. Slide no. $648,41 \hat{\mu}$ in diameter, from $191-2-1(50-52 \mathrm{~cm})$, Denticula seminae Zone, upper Pleistocene. $\times 1000$.

Figures 7-9 Thalassiosira punctata Jousé. Slide no. $815,54 \mu$ in diameter, from 192-19(CC), Denticula kamtschatica Zone, upper Miocene. $\times 850$.

Figure 10 Thalassiosira zabelinae Jousé. Slide no. 522. $58 \tilde{\mu}$ in diameter, from 189-6-1(84-86 cm), Thalassiosira zabelinae Zone, upper Pliocene. X800.

Figures 11-12 Thalassiosira zabelinae Jousé. Slide no. $664,43 \mu$ in diameter, from 191-5-6(70-72 cm), Rhizosolenia curvirostris Zone, middle Pleistocene. $\times 1000$.

Figures 13-14 Thalassiosira usatschevii Jouse. Slide no. 436, $91 \mu$ in diameter, from 187-3(CC) (Lst), Denticula kamtschatica Zone, upper Pliocene. X600.

Figure 15 Thalassiosira usatschevii Jousé. Slide no. 132, 85 diameter, from 183-11-1(80-82 cm), Thalassiosira zabelinae Zone, upper Pliocene. $\times 700$.

Figure 16 Thalassiothrix longissima $\mathrm{C}$. and Grun. Slide no. $431,137 \mu$ in length, from 187-1(CC) (Lst), Denticula seminae Zone to Actinocyclus oculatus Zone, Pleistocene. 
PLATE 8

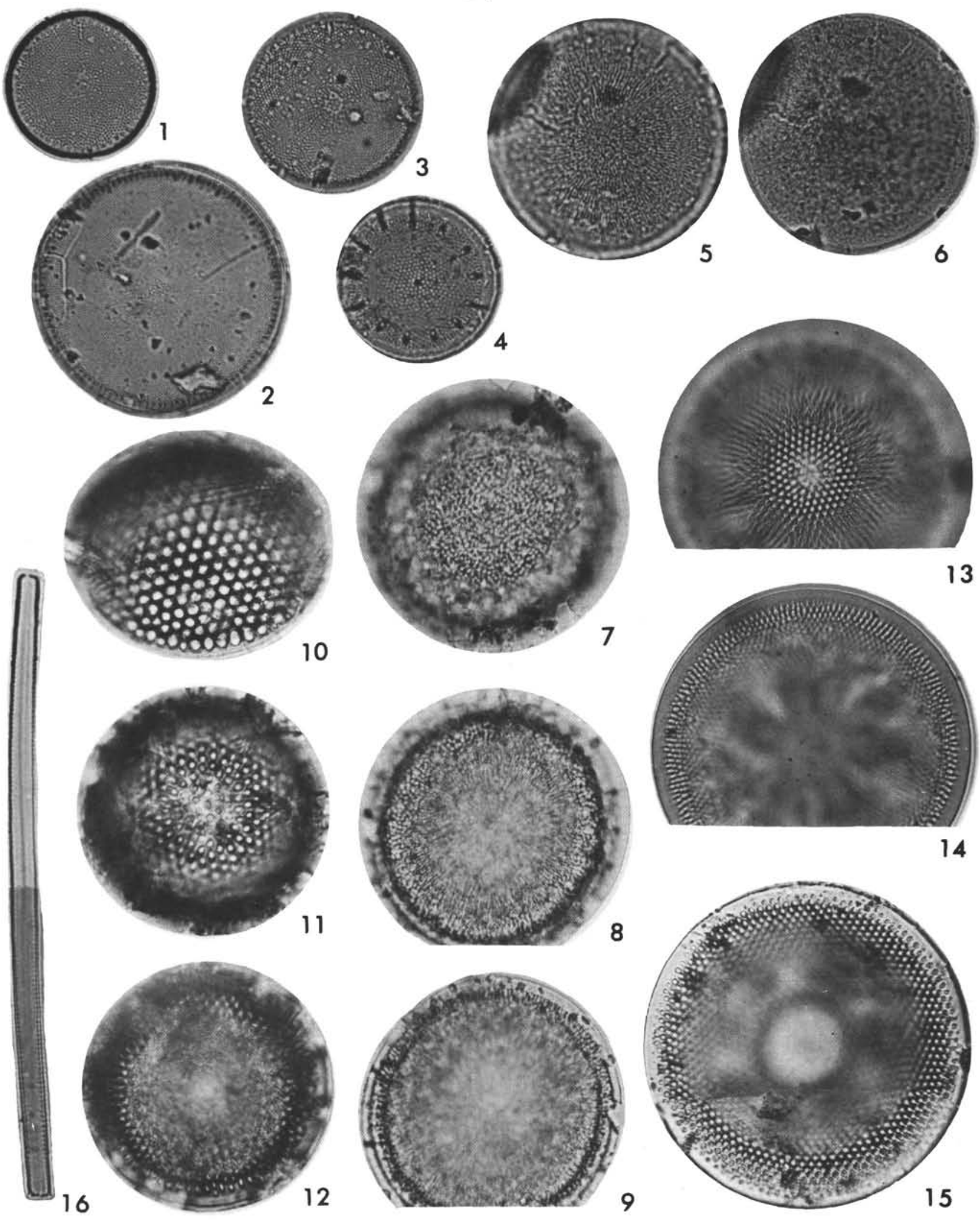

